\title{
The Woodlands: Archeological Investigations at the Sam Houston Home, Huntsville, Walker County, Texas
}

John W. Clark Jr.

Prewitt and Associates, Inc.

Follow this and additional works at: https://scholarworks.sfasu.edu/ita

Part of the American Material Culture Commons, Archaeological Anthropology Commons, Environmental Studies Commons, Other American Studies Commons, Other Arts and Humanities Commons, Other History of Art, Architecture, and Archaeology Commons, and the United States History Commons

Tell us how this article helped you.

This Article is brought to you for free and open access by the Center for Regional Heritage Research at SFA ScholarWorks. It has been accepted for inclusion in Index of Texas Archaeology: Open Access Gray Literature from the Lone Star State by an authorized editor of SFA ScholarWorks. For more information, please contact cdsscholarworks@sfasu.edu. 


\section{The Woodlands: Archeological Investigations at the Sam Houston Home, Huntsville, Walker County, Texas}

\section{Creative Commons License}

\section{(c) (1) $\Theta(9$}

This work is licensed under a Creative Commons Attribution-NonCommercial-No Derivative Works 4.0 International License. 
THE WOODLANDS: ARCHEOLOGICAL INVESTIGATIONS

AT THE SAM HOUSTON HOME, HUNTSVILLE, WALKER COUNTY, TEXAS

By

John W. Clark, Jr.

PRINCIPAL INVESTIGATOR: Elton R. Prewitt

REPORTS OF INVESTIGATIONS, NUMBER 4

Prewitt and Associates, Inc.

Consulting Archeologists

Austin, Texas

January, 1980 
Report submitted to Sam Houston Memorial Museum, Huntsville, Texas, by Prewitt and Associates, Inc. in fulfillment of the terms of Purchase Orders No. 9-5617-701248 and No. 0-1554-701248. These investigations were conducted under the terms of Antiquities Permit Number 215 issued by the Texas Antiquities Committee, Austin, Texas, on 21 September 1979 . 
TABLE OF CONTENTS

Page

FOREWORD

vi

ABSTRACT ..................... . . . . .

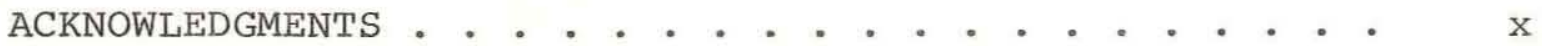

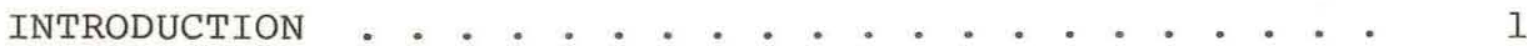

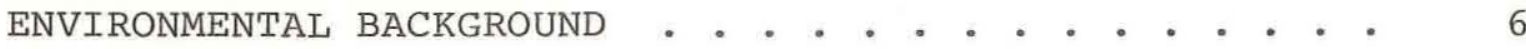

HISTORICAL BACKGROUND . . . . . . . . . . . . . . 7

ARCHITECTURE AND CONSTRUCTION HISTORY . • . . . . . . 18

ARCHEOLOGICAL STRATEGIES . . . . . . . . . . . 25

SOILS . . . . . . . . . . . . . . . . . 28

ARCHEOLOGICAL FEATURES . . . . . . . . . . . . . . 29

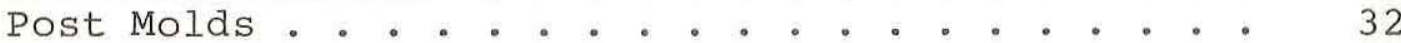

Pits . . . . . . . . . . . . . . . . 32

Trenches . . . . . . . . . . . . . . . . 37

Sill Beams . . . . . . . . . . . . . . . . . 37

Foundation Walls . . . . . . . . . . . . . 39

Piers .................... . . . . 4 42

Floors...................... . . . 44

Chimney Foundations . . . . . . . . . . . 45

NONARCHEOLOGICAL FEATURES . . . . . . . . . . . . . 45

Worm Tubes.................. . . . 45

Rodent Runs . . . . . . . . . . . . . . 46

Root Casts . . . . . . . . . . . . . . 46

Plow Zone ................. . . . 46

Sprinkler Lines . . . . . . . . . . . . . 46

Water Lines . . . . . . . . . . . . . . . 46

Gas Line . . . . . . . . . . . . . . . . 47

Electrical Lines .. . . . . . . . . . . . 47

Air Conditioner Pipes . . . . . . . . . . . 47

Sidewalks . . . . . . . . . . . . . . . . 47

SUMMARY OF FEATURES . . . . . . . . . . . . . . . . 48

ARTIFACT DISTRIBUTION • . . . . . . . . . . . . . . 49

SUMMARY OF ARTIFACTS . . . . . . . . . . . . . 50

INTERPRETATION OF ARTIFACTS . . . . . . . . . . 52 
Page

CONCLUSIONS . . . . . . . . . . . . . . . . . . . 54

RECOMMENDATIONS . . . . . . . . . . . . . . . . 55

REFERENCES CITED . . . . . . . . . . . . . . 59

APPENDIX 1: Artifact Descriptions . . . . . . . 65

APPENDIX 2: Test Excavations for the

Sam Houston Law Office . . . . . . . 155 
Page

1. General site plan . . . . . . . . . . . . 5

2. General site and excavation photographs . . . . 27

3. Plan of structures, excavations and features . . 31

4. Profiles of Test Pits . . . . . . . . . 35

5. Floor Plans of Test Pits . . . . . . . . . . 41

6. Ceramic, metal and glass artifacts . . . . . 69

7. Glass artifacts . . . . . . . . . . . . 77

8. Metal, glass and bone artifacts . . . . . . 93

9. Metal and bone artifacts . . . . . . . . . 111

\section{LIST OF TABLES}

1. Post molds ............... . 33

2. Pits ................. 36

3. Trenches ................. 38

4. Provenience chart . . . . . . . . . . . 140

5. Provenience of artifacts from

Corbin testing of law office . . . . . . . 157 
FOREW ORD

The following report prepared by John W. Clark, Jr. presents the findings made during archeological excavations carried out at the site of Sam Houston's home, "The Woodlands," in Huntsville, Texas. The primary aim of the excavations was to search for evidence of the original alignment and character of the Houston Home in order to assist efforts to restore the structure to its original configurations. Of particular concern were the original location of the house, the character of the original chimneys and a determination of the presence or absence of a front porch. This mission was only partially successful due to repeated disturbances in and around the site during more than a century of use following the Houston occupation. The alignment and structural character of the rear of the house were documented; however, subsurface evidence of the chimneys and the porch appear to have been destroyed during the years after Sam Houston moved from "The Woodlands."

A secondary aim was to locate the original kitchen site if possible. Evidence from the excavations suggests that the representative kitchen structure which currently exists at the site is situated in approximately the same position as the original detached kitchen. No structural details of the Houston era kitchen were encountered. The final aim of these investigations was to provide documentation of the nature and extent of several additions to the original house which were made during the latter part of the 19th Century. Substantial structural evidence relating to this period of occupation was uncovered in the excavations.

Although this report is traditionally descriptive in nature, Mr. Clark has done an admirable job in condensing 
a large body of data into manageable form. The information presented in this report should prove helpful in obtaining historical accuracy in the restoration program now under way at the Houston Home.

\author{
Elton R. Prewitt \\ Principal Investigator
}


Intensive archeological excavations in september and october 2979 at the Sam Houston House, Huntsvilze, Texas, resulted in the accumulation of data regarding the original house location, additions to the house and the location of the original kitchen. A number of features attributable to each of these three major structures was encountered. The extensive artifact inventory provides data on use-activity centers and relative economic position. Although modern disturbances have destroyed portions of the archeological evidence, particularly adjacent to the present house location, substantial l9th Century deposits are undisturbed and potentialzy may provide a great deal more data about the site. 


\section{ACKNOWLEDGMENTS}

An intensive excavation such as this one involves the collaboration of a large number of people in all aspects of the project. Prime movers of the project were sue Flanagan, Director of the Sam Houston Memorial Museum; the Sam Houston State University regents; David Hoffman of the architectural firm of Bell, Klein and Hoffman; Curtis Tunnell, State Archeologist; LaVerne Herrington, State Antiquities Committee and James E. Corbin of Stephen F. Austin State University. Hoffman and Corbin provided data and consultation before, during and after the excavation phase of the project.

Field work was performed by Susan Andrews, Steven Kotter, Jan Guy, Ross Fields, Jerrilyn McLerran and Stephan Krug with occasional help from Charlie Bennett and his grounds crew. Laboratory work was patiently done by Linda Nance and Jan Guy, who devoted considerable time to the partial restoration of several bottles and ceramic sherds. Sandra Hannum did the drafting.

The museum staff and a number of visitors were consistently interested in the project and often provided cogent and valuable information concerning the grounds and history of the site. One visitor, Alexander T. Redditt, provided considerable help by loaning and operating his metal detector which allowed the rapid location of the additions to the house.

Final preparation of the typed copy and editing were accomplished by Linda Nance and Elton R. Prewitt. Their comments and help were invaluable in the production of the final report. 
INTRODUCTION

Archeological investigations were conducted at Sam Houston's Home, "The Woodlands," during the Fal.1 of 1979 by Prewitt and Associates, Inc. The Houston Home is recorded as site 4 IWA46 in the files of the Texas Archeological Research Laboratory, The University of Texas at Austin. Owned by Sam Houston State University, the Houston Home is located within a museum and park complex adjacent to the University campus in downtown Huntsville. The house is listed on the National Register of Historic Places and has been designated as a National Landmark; it is also a State Archeological Landmark under the provisions of the Texas Antiquities Code. The current investigations were conducted under the provisions of Antiquities Permit Number 215 issued by the Texas Antiquities Committee.

The faculty, staff, regents and students of Sam Houston State University have shown continued interest in the preservation of the Sam Houston house; efforts by faculty and students to purchase the property and to relocate buildings on the site began in 1907. Since that time, interest in the site has continued and is demonstrated through the periodic renovations, landscapings and the current intensive use of the structure in the museum complex. Concern for the site resulted in an architectural study by Bell, Klein and Hoffman of Austin during 1975, and this led to the funding of the archeological excavations herein reported.

The architectural study raised a number of important questions which could be pursued only through archeological investigations. Among these questions were: (1) was the house returned to its original site? (2) What kind were the original chimneys? (3) Did the house have a front porch? 
(4) Is there evidence of the size and location of various additions and outbuildings? Initial archeological investigations were made adjacent to the law office and the house. These investigations were essentially negative, although the excavations adjacent to the house did reveal an alignment of post molds and a midden dating to the late 19th Century. On the basis of these findings, additional excavations were performed; these resulted in the definition of the late 19th Century additions, the exposure of portions of the rear foundation of the house and the identification of a portion of the original kitchen. Monitoring of the excavation of an electrical burglar alarm line revealed the possibility of locating the original site of the law office.

Excavations were funded by the Sam Houston Memorial Museum which is a unit of Sam Houston State University. The work was sponsored as a preliminary step in planned restoration and conservation of the house and law office to be done by the architectural firm of Bell, Klein and Hoffman.

The Houston Home is situated within a 15.5-acre park and museum complex adjacent to the west side of the University campus. The house, Houston's law office "and a reconstructed kitchen are enclosed in a picket-fenced yard. A later house occupied by Houston, the War and Peace House, a greenhouse and a mid-19th Century structure moved from northeast Huntsville are arrayed along the west side of the complex while a landscaped pond fed by an altered spring outlet occupies the eastern side of the complex. A formal museum structure dedicated to Sam Houston is located in the northeast corner of the complex; this building also houses 
the administrative offices associated with the museum. None of the 19th Century structures appear to be situated on their exact original locations (Fig. 1).

During the early 20th Century, all of the 19th Century structures were removed from their original sites; the house and law office were later returned. The reason for this removal is not clear. The current excavations have provided information pertaining to the original locations of the house and the kitchen, and provide evidence of disturbances incurred when the house was moved. A major problem encountered on the north and east sides of the house consists of a myriad of mid-to-late 20th Century disturbances. These disturbances have obscured post hole patterns, have contributed to increased mixing of 20th Century debris with 19th Century midden deposits and made excavation difficult and, at times, dangerous. Considering these disturbances, including plowing, grading and filling, it is estimated that about $50 \%$ of the midden deposits remain undisturbed and about $80 \%$ of the subsurface archeological features are intact; however, in the area adjacent to the northern half of the present house location, it appears $100 \%$ of the 19th Century deposits and features have been disrupted or destroyed. Indeed, the intensity of the 20th Century activity at the site is such that it is surprising that intact deposits and features are extant.

There is a strong probability that archeological remains of other outbuildings are present and undisturbed. The possibility of finding front pier and sill remains is considered to be moderate. There appears to be virtually no possibility of finding l9th Century chimney foundations at the house due to disturbances incurred during relocation and chimney construction activities. 
Figure 1. General site plan. 


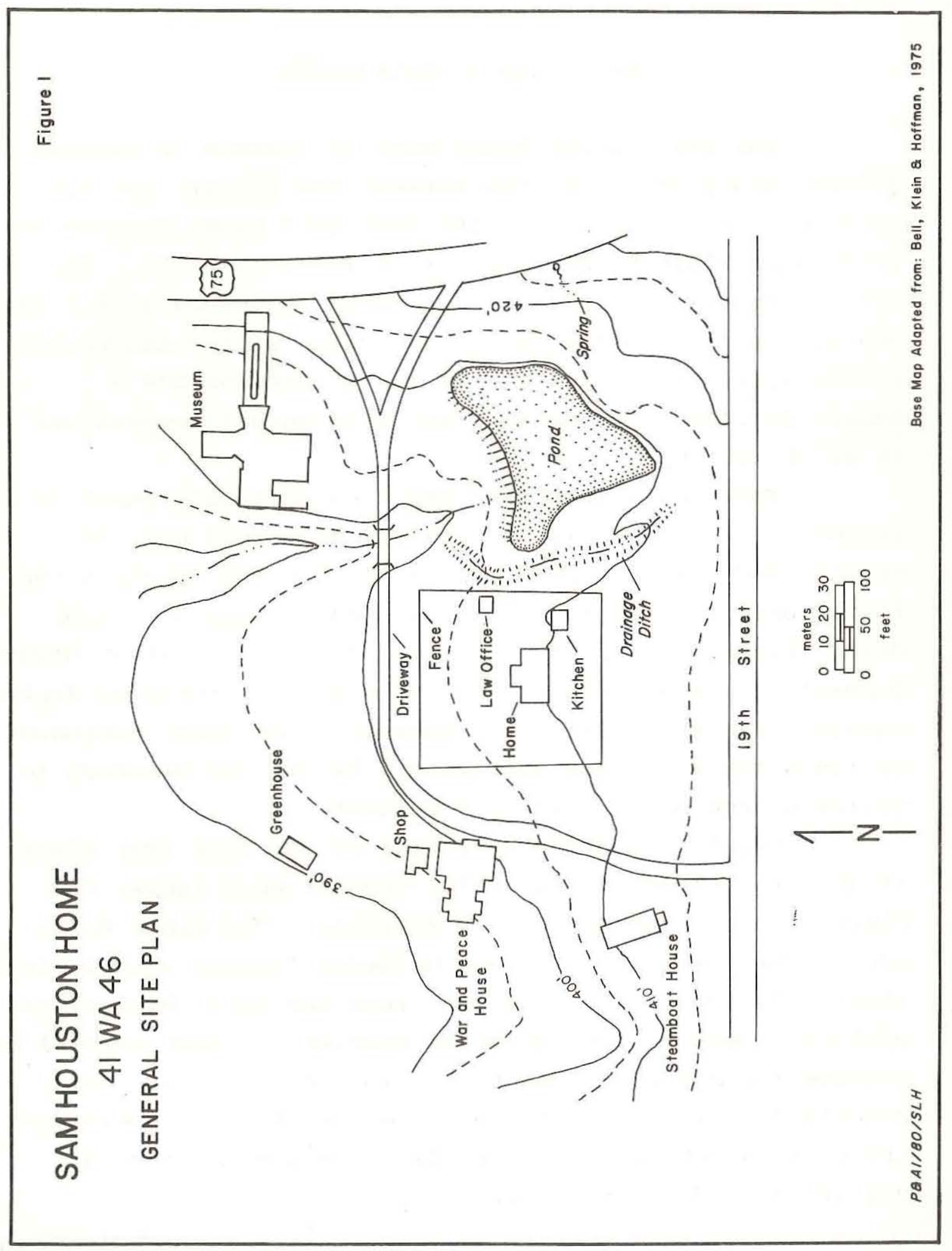




\section{ENVIRONMENTAL BACKGROUND}

The Sam Houston house site is located in central Walker County on the divide between the Trinity and San Jacinto river drainages in the west Gulf Coast Section of the Coastal Plain Physical Province (Carr 1967: 3). The average annual precipitation is about 45 inches (114.3 cm.) and occurs principally during the fall, winter and spring (Ibid: 4,6); this results in a winter surplus and a summer deficiency of water. The mean annual temperature is $68^{\circ} \mathrm{F}\left(21^{\circ} \mathrm{C}\right)$.

The area is south of the Kisatchie Escarpment in a region of rolling hills and prairie developed over the Fleming and Goliad Formations of the Neogene Epoch; these formations are composed of sands, sandy loams and sandy clays (Fisher et al 1965: 24,31). At the site these Neogene deposits are shallowly buried and are encountered at depths varying from 40-55 cm. They consist of an upper component of light tan fine sand overlying a bright yellow-brown to yellow-orange sandy clay (wet colors).

Vegetation characteristics of the site area place it near the border of two major vegetational areas; the Piney Woods and the Blackland Prairies. The Piney Woods area comprises mixed pine and hardwood forests with loblolly, shortleaf, long leaf and slash pines and oaks, hickory and maple as commercially exploited species. Forest removal has allowed ranches and farms to develop in the area. The Blackland Prairie association is generally to the west of the site and characterized by little bluestem and other grasses (Gould 1969: 10-11).

There is a variety of animal life associated with the region; many of these are ecologically associated with 
nearby riparian environments. Common mammals in the area at present include the following: raccoon, ringtail, longtailed weasel, mink, eastern spotted skunk, striped skunk, red fox, gray fox, cougar, bobcat, eastern gray squirrel, fox squirrel, eastern flying squirrel, plains pocket gopher, hispid pocket mouse, fulvous harvest mouse, pygmy mouse, white-footed mouse, cotton mouse, northern rice rat, hispid cotton rat, Florida wood rat, California jackrabbit, Eastern cottontail, swamp rabbit, white-tailed deer and nine-banded armadillo. There have been several animals extirpated from the area; these include the grizzly and black bear, river otter, gray wolf, red wolf, beaver, peccary, elk and bison. There have also been a number of animals introduced to the area such as the coyote, house mouse, roof rat, Norway rat and nutria (Davis 1974).

\section{HISTORICAL BACKGROUND}

Sparse information is available for the Huntsville area during the Spanish Colonial period. It is possible that Captain Joaquín Orobio Bazterra passed through the vicinity during 1746 when he returned to La Bahia (Goliad) to investigate the possibility of an illicit French settlement on the lower Trinity River (Bolton 1970: 64-65). Since the area was not on the major roads nor near the centers of population at Nacogdoches, Nuestra Señora del Pilar de Bucareli and El Orcoquizac, it was not a focus of Spanish activity. After Mexico won its independence and adopted the constitution of 1824, the immigration of foreigners was allowed in an attempt to improve economic conditions. This has been succinctly summarized by Jimenez Moreno and Garcia Ruiz:

"De la Colonia heredó el México independiente múltiples circumstancias desfavorables para 
continuar su desarrollo dentro de las normas de cultural moderna, que desde el Siglo XVIII vimos que llegan a ser predominantes. El problema de sus fronteras indefinidas, en especial frente a la colonización anglosajona, socíedad más homogénea por su origen y menos complicada por carecer del problema indígena -que generalmente resolvió de otra manera -- y que provocó, hacia 1835, el conflicto de Texas, y en 1846 el de la invasión norteamericana." (Jimenez Moreno y Garcia Ruiz 1970: 50).

From the Colonial period, independent Mexico inherited multiple unfavorable circumstances for the continuance of its development within modern cultural norms such that from the 18 th Century we see that they [Colonial norms] became predominant. The problem of its [Mexico's] indefinite borders, especially facing the Anglosaxon colonization, a more homogeneous society in its origin and less complicated with regard to its Indian policy -- which was generally resolved in another way - resulted in the Texas conflict about 1835 and in 1846, the North American invasion. (Translation by the author).

These problems attracted adventurers, drifters and refugees into east Texas (Meinig 1975: 26), an area unattractive to Spanish ranchers and spanish-style ranching because of the heavy woods. Most of these people filtered across the Louisiana frontier from the lower south. Meanwhile, Moses and Stephen F. Austin contracted with the liberal Mexican government to settle a specific area which became known as Austin's Colony. This colony was expanded in 1824 to include the area from the coastline to the Camino Real de San Antonio and from the Lavaca River to Chocolate Bayou (Ray 1970: 9). Thus, the area of Walker County fell within Austin's Colony.

Conservative reaction to the 1824 liberal constitution resulted in a coup d'état by President Bustamante 
which was supported by the wealthy and powerful gauchupin element in Mexico. The indigenous and mestizo elements, much more numerous, rose up in revolt in several states of Mexico. Among these uprisings, and by no means the first, was the Texan which included among its prime supporters the great liberal Lorenzo de Zavala.

Revolts had begun in other states of the Republic, but Texas maintained an uneasy equilibrium. Another coup d'état by Antonio Lopez de Santa Anna which was supported by liberal factions tended to reduce conflicts for a time until Santa Anna's dictatorial designs became evident. Sam Houston entered this troubled arena at the end of 1833. In a letter to Andrew Jackson, Houston proposed to remain in Texas and specified the problems, including civil war and bankrupt economy, which weakened Mexico's military position and ability to retain Texas if the state were to be separated from the nation (James 1975: 160).

Early in the century there were designs among a number of people in the "colossus of the North" to wrest Texas, Nuevo Mexico, Arizona and Alta California, as well as Tamaulipas, Nuevo Leon, Coahuila, Chihuahua and Sonora from Mexico. It was even proposed to annex the entire nation; among the principal adherants to this idea were people such as Aaron Burr and Andrew Jackson. This imperial impulse, neo-colonialism, culminated in the activities which were later termed manifest destiny. An early example of this impulse was the GutierrezMcGee expedition against Bexar and Matamoras.

Among the drifters and adventurers entering Texas as illegal immigrants were a number of people who were adherants, for their own purposes, of this idea. As stated by Jimenez Moreno and Garcia Ruiz (1970: 50), the borders were imprecise and long with few resources for patrol. 
It was impossible to apprehend and deport more than a small fraction of those entering the country through Texas. William B. Travis and Sam Houston were among these immigrants. Houston placed himself into the political situation where he was able to maintain flexibility to maneuver and take advantage of new developments. These changes were not long in coming. The Mexican government under Santa Anna overturned the 1824 constitution and substituted a rightist regime. Revolts began immediately. Santa Anna, hero of the war for independence, and his generals suppressed the liberal revolts thereby gaining considerable expertise and training for the troops. Texas held out for awhile before it too revolted. Initially the demand was for restoration of the constitution, but the manifest destiny element soon took control from the more moderate citizens. A rag-tag military force was loosely organized under various individuals, mostly filibusterers. A number of skirmishes took place near and in San Antonio de Bexar resulting in the ouster of the Mexican garrison. Other garrisons were withdrawn and their personnel assembled at Matamoros and San Juan Bautista. In response, the Texans made an attempt to organize a more formal military force. This was extremely difficult because of the filibustering tradition and allegiance to individual leaders. Houston was placed in command of the principal force with subcommands under Travis and Fannin. Positions were assumed at Bexar, La Bahia (Goliad) and at lesser locales such as Tenoxtitlan and Anahuac.

The defection of Texas from the nation came as no surprise to the national government. Earlier, the colonial government had feared encroachment from the English colonies and the Mexican government had heard the plans for an empire 
in the west and had had experience with the Gutierrez-McGee expedition. The president and his generals collected a force at Saltillo with which to put down the rebellion in Texas. In February of 1836 the army began moving north to San Juan Bautista. The march was plagued by cold and hail, the lack of water and food and unsympathetic officers (de la Peña 1975: 32). The army became strung out and required considerable time to cross the Rio Bravo del Norte (Rio Grande). The assembly point was to be the presidio at Bexar.

After crossing the Rio Bravo the force split; the main force continued toward the assembly at Bexar while the remainder was directed to eliminate rebel garrisons at La Bahia and Gonzales. The Texan garrison at Bexar was commanded by William B. Travis, while that at La Bahia was commanded by James Fannin. Both had orders to withdraw and to destroy defensible positions. Both officers vacillated and finally decided on suicidal courses of action which vainly flaunted their independence from Houston.

Following the arrival of the vanguard of Santa Anna's forces, it took 12 days to reassemble the strung-out army and to arrange the siege cannons around the former mission of San Antonio de Valero, sometimes called El Alamo after a company of light cavalry stationed there following the war for independence. The story of the battle is well known from Texas history books, movies and television. Perhaps the best and most easily available non-Texan version is the book by de la Peña (1975).

Following the battle Santa Anna took several days to clean up the battlefield, pull down the walls of the mission compound, dispose of the dead and tend the wounded. He then divided his force to pursue small bands of rebels near Victoria, Mina (Bastrop) and San Marcos. Santa Anna 
led the remainder of the army in pursuit of the main Texan force commanded by Houston. Santa Anna had two objectives: (1) to capture the rebel government, and (2) eliminate the military force in his front. Houston's strategy appears to have been to withdraw in face of the enemy; this act left burned farms and scant resources behind him.

On hearing that the rebel government had moved to Harrisburg, Santa Anna separated a force of about 1100 infantry, 70 cavalry and one six-pounder cannon and marched to the San Jacinto River (de la Peña 1975: 128). The general made camp near Lynch's Ferry on the 21st of April and subsequently received reinforcements from the division commanded by Martín Perfecto de Cós. Confident of victory, pickets were not posted. Observing this, Houston gathered his force and made a surprise attack on the camp, completely overwhelmed it, and captured the president.

The treaty of Velasco ended hostilities for the moment and all Mexican troops withdrew to the area south of the Rio Bravo although Mexico legitimately contended that the border was the Nueces River. This claim was based on the colonial boundaries of Nuevo Santander, Texas and Coahuila; however, the Texans claimed the Rio Bravo as the frontier.

Houston was the hero of the moment. Although he had been highly criticized for not fighting sooner and for virtually abandoning Texas in his withdrawals, all was forgotten. He was nominated and elected president under a newly drafted constitution copied from that of the United States.

Meanwhile, two factions developed; one desired to annex Texas to the United States and the other wished Texas 
to remain independent. Houston preferred that Texas join the United States, and he worked hard in the cause for annexation. After Houston's first term as president, he visited Jackson and met his future wife. It was at this time that the administration of Mirabeau B. Lamar selected the community of Waterloo as the new capitol city of Austin. Houston established himself and his new wife at the new site of Houston city after having resided briefly in san Augustine. During Lamar's administration, many of Houston's policies were renounced; chief among these were his liberal Indian policy and annexation to the United States. It was during Lamar's administration that Alphonse de Saligny opened a French legation in Austin.

Houston was reelected president after Lamar's term and continued to work toward annexation. A major problem developed regarding annexation because of the political balance problem in the United States. The economic and political balance would have tipped to the south had Texas been admitted as a slave state. Houston opposed the existence of Austin as capitol in favor of Houston city and moved most of the government there; the reasons were, in part, because of Austin's association with the Lamar administration, because of its exposure to Indian depredations and because of Mexican incursions as far north as Bexar and San Marcos. The archive war followed in which the archives were retained in Austin.

During the succeeding Anson Jones administration, annexation was approved by the United States and accepted by Texas. Houston was then elected to the U.S. Senate. Manifest destiny were the key words and the Rio Bravo was accepted as the state's southern boundary. Mexico could 
not accept this and attempted to maintain patrols and a garrison north of Matamoros to protect the towns of Dolores, San Ygnacio and Laredo, all of which had been founded as towns of Nuevo Santander (Tamaulipas).

From the end of the Texas Revolution in 1836 to the period of annexation in 1845, there were constant raids by Mexican troops north of the Nueces River and by Texans south of the Rio Bravo. Bitterness and cruelty prevailed and increased with each raid. For the United states, these raids served as a pretext for expansion which culminated in the taking of Nuevo Mexico, Arizona and Alta California. Shortly after annexation, General Zachary Taylor was sent to the Nueces River. Elements of the U.S. Army were then sent south to establish a fortified position opposite Matamoros. Hostilities quickly erupted in the battles of Palo Alto and Resaca de la Palma and the subsequent capture of Matamoras.

After the Mexican War the federal government established a series of forts with which to protect the frontier with Mexico and to protect the numerous new settlements from Indian raids. Plantations in the eastern part of the state continued to grow in a boom economy. However political unrest in the United States posed increasing problems. The north-south power struggle increased in vigor and emotional radicalism with the addition of new territories to the nation. These problems were much deeper than the question of slavery; that emotional issue was a surface manifestation which masked the deep economic and social differences between the northern industrial states and the southern cash agricultural states. 
While this storm was brewing, Houston was elected governor of Texas in 1859. He so strongly opposed secession that he refused to take the Confederate oath of allegiance in 1861 and was replaced as governor. He returned to Huntsville and died there in 1863.

Reconstruction was extremely difficult for Texas and occasionally resulted in riots -- including serious troubles in Huntsville.

The community of Huntsville was established in 1836 by Pleasant and Ephraim Gray as an Indian trading post. In 1844 Thomas and Sanford Gibbs built a general store. This enterprise became a bank which later was the First National Bank of Huntsville. A newspaper was established in 1845, and a Baptist church was also built; this was followed quickly by other churches and reflected the population growth of the area. A number of schools, academies and universities were established in the community at various times beginning in 1840. Among these was Sam Houston Normal Institute which was established in 1879. This became Sam Houston State Teachers College and finally Sam Houston State University.

The Texas Department of Corrections (state penitentiary) was established in Huntsville in 1849. In 1872 a railroad branch line was built to Huntsville (Webb and Carrol1 1952: 867).

Huntsville and Sam Houston are very closely associated. On December 7, 1847, Houston bought 2.5 acres from George Rogers, and by 1850 he had assembled 234 acres which included 174.5 acres purchased from F. L. Hatch (December 7, 1847). Houston apparently built his home on this tract (Bell, Klein and Hoffman 1975: 22). He also received bounty 
warrant 3894 for 1280 acres in San Patricio County which was patented to his heirs in 1874 (Miller 1967: 357) and a donation certificate for 640 acres in Walker County patented to him on March 7, 1849 (Ibid: 790). This placed Houston in control of 2154 acres in Walker and San Patricio Counties. He later purchased another 57 acres in Walker County and increased his holdings to 2211 acres.

Apparently Houston had his home built in 1847 and occupied it in the autumn of that year. He apparently was satisfied with it and wrote "But my friend, I assure you, when I am at home, in my woodland residence, with my wife and brats, I feel no disposition to return again to the scenes of official conflict and disputation . . . This is too long an absence for a man who loves his home and family . . Y You must suppose that mine must be extremely pleasant. Well, I think my family are so, and that adds charm to my rustic habitation." (Barker and Williams 1941: 298). His wife Margaret seems not to have entirely shared his love of the site. In 1853 Houston purchased a residence in Independence and sold his Huntsville property in 1858 to J. Carroll Smith. After Houston was forced from office in 1861, he attempted to repurchase this property but was unable to do so. He then rented a house on the northeastern edge of Huntsville. Smith sold the former Houston property to J. W. Bush in 1862; Bush occupied the site 14 years before selling it to $T$. W. House in 1876. House sold the property to S. Smedes that same year (Bell, Klein and Hoffman 1975: 24-25).

Smedes converted the log house into a girls' boarding house and built several additions to the original 
structure. Smedes sold six tracts from the original tract between 1889 and 1901. The remainder of the property was sold to A. T. and Will Randolph in 1901. For some reason which was never made clear, the additions were removed and the house moved about 300 meters northeast of the original site. The "law office" had previously been moved (Bell, Klein and Hoffman 1975: 27).

A history teacher at Sam Houston Normal Institute Bertha Kirkley, initiated a movement to restore the Houston home and grounds. Student efforts raised money to purchase 2.5 acres of the original homesite in 1908 and 6.8 acres in 1909 with an additional five acres surrounding the spring. In 1911 both the house and "law office" were purchased and moved back to the property.

The School of Agriculture was permitted to use the grounds for planting experimental crops around the home. The house was used as a hay barn at that time, and pens, dipping vats and stables occupied other parts of the property. A fire in 1925 damaged part of the house, and the agricultural practices apparently resulted in erosional damage around the spring.

These conditions led J. L. Clark, a history professor at the college, to request money from the state legislature to restore and develop the house and site. Between 1927 and 1929 a great deal of structural and landscape work involving filling and grading the grounds was accomplished. Additional work was done in preparation for the Texas Centennial, and minor modifications have been made since that time.

For additional biographical information on Houston, the reader is referred to James (1975) and Friend (1954). 


\section{ARCHITECTURE AND CONSTRUCTION HISTORY}

The Sam Houston house, although made of saw cut pine logs (Bell, Klein and Hoffman 1975: 43), is typical of the southern "dog-run" houses which probably originated in Virginia (Morrison 1952: 168-170). Alexander and Webb (1966: 11) distinguish log cabins which were made of round logs and log houses made of squared logs. Roofs were simple gables oriented to the ends of the house with ridges extending the entire length (Ibid: 12) and with sufficient attic space for use as sleeping lofts. If a porch were placed on the structure, doors for the two rooms of a "dog-run" house would generally open onto the porch (Ibid: 13).

The original portion of the house is 19.19 meters long by 5.75 meters wide; additions increase the width to 8.9 meters. It is composed of two log rooms with an intervening hall. The two log rooms are square, are 5.75 meters to the side, and the hall is 7.7 meters wide. The upper half-story floor plan is the same. The mill-sawn planked pine logs are $23-28 \mathrm{~cm}$. wide and $9 \mathrm{~cm}$. thick with tops and bottoms which are either untrimmed or roughly trimmed. The logs are spaced $2.5-5 \mathrm{~cm}$. apart and are square notched. Horizontal nailed rived boards were used to chink the logs on both the interior and exterior walls. These chinking boards average $10.2 \mathrm{~cm}$. wide.

The foundation sill measures 17.8 by $40.6 \mathrm{~cm}$. (virtually the same width as the sill elements encountered in the excavations). The upper half-story interior walls were constructed of exposed vertical studs. The rafter plate is $10 \mathrm{x} 25 \mathrm{~cm}$. and is cantilevered on the gables. The rafters are nailed directly to the top surface of the 
plate and butted together at the ridge; there is no ridge pole. The half-story facade is characterized by a grill of vertical members morticed into the plate between the two pens.

Two windows appear in the north wall of each of the two pens and two small windows appear in each of the gable ends in the half-story. These elements appear to be associated with the original house construction.

Siding was apparently added at a later date and consists of two general types: horizontal boards and board and batten. The horizontal siding is mill-sawn pine 14-18 $\mathrm{cm}$. wide and $.3-1.3 \mathrm{~cm}$. thick fastened with $7 \mathrm{~d}$ nails. On the rear of the structure evidence of board and batten siding spaced differently from the modern board and batten siding was noted.

Considerable evidence of burning at the southwest corner and south half-story hall walls was revealed in architectural probes. The half-story studs and several lower logs show evidence of whitewash. Evidence for additions to the rear of the structure consists of clusters of cut nails which apparently resulted from toe nailing rafters at the second from the top log, $i . e$, below the rafter plate. These were nailed directly to the board and batten sheathing.

Ephemeral evidence for the existence of a front porch was noted; the upper logs do not appear to be as weathered as the lower logs. This variation could be accounted for by overhanging eaves. The only other evidence relating to the porch which was encountered in the architectural probes by Bell, Klein and Hoffman (1975: 47-63) consists of two notches cut below the second floor joist notches. Again, these notches may have resulted from later activities at the site. 
Other features of the house include two modern brick chimneys made with branded brick dating between ca. 1880 and 1945 (Kelley and Kelley 1979: 84) and a neoclassic porch. On the rear of the structure there are two small room additions on either end of a shed-roof porch.

Also on the site are a log structure said to have been Houston's law office and a recent log structure representing the kitchen. Brand brick sidewalks approach the house from the north and parallel the rear of the structure from the kitchen to the west parking lot. Another brick walkway extends south to the end of the yard which is bounded by a picket fence.

The Houston log house is in the portion of Texas dominated by the architecture and culture of the lower south. The tradition of story-and-a-half dog-run houses built on relatively high post or brick piers spans much of the lower south from Virginia and Tennessee (where Houston was born and lived before coming to Texas) to the Carolinas through eastern Texas (Jordan 1978: 13,32).

It is interesting to compare the Houston log house to the usual one-and-a-half story structures. An obvious difference is the orientation of the house. The Houston home was oriented to the north whereas Jordan $(1978$ : 31)! notes that only $8 \%$ of the houses he examined were so oriented. Otherwise, the structure is very similar to a common style of house throughout the lower south. In these houses chinking most commonly was rived boards placed on the interior (Ibid: 43). The one-and-a-half story structure often had floor joists morticed into notches two to three logs below the rafter plate (Ibid: 133) which were often cantilevered and projected beyond the end walls (Ibid: 85,86$)$. Log houses generally 
reflected low social status (Ibid: 5-9) and they were often covered with siding as soon as practical. Houston, being a Jacksonian Democrat, valued the political appeal of the log house. Horizontal siding was an early sign of economic success while board and batten siding was generally confined to those of lower economic status. Painting and whitewashing of log structures was rare (Ibid: 46), but shed rooms were commonly added to the rear, and if a front porch was present, it extended the length of the house (Ibid: 137).

A brief analysis of the structure then reveals several interesting points. First, the Sam Houston log house is structurally weak because of the square notching of the logs and the lack of a ridge pole. Evidence of this weakness can be seen in the irregular ridge line and surfaces of the roof, and the displaced logs behind the siding which were revealed in the architectural probes. The orientation of the house and the whitewashing of the logs are unusual. However, the remainder of the features are common and can be seen in other examples such as the Oliphant and Gains-McGowan houses in Sabine County, the Morehead-Gano house in Dallas County, the house in the Dallas old City Park Restoration from Tarrant County and many others. Alexander and Webb (1966: 13) note that "... if a porch extended across the front the doors might also open onto it." Houses with no porch generally opened onto the run or hall. Stylistically, then, the Houston house would suggest the lack of a front porch at an early date; however, the physical evidence is inconclusive.

Summary of Major Events Sam Houston Home

1847 Construction of house, kitchen, law office, latrine, servant house and possibly other outbuildings 
1853 Houston's occupation ends

1858 Property sold to J. Carroll Smith

1878 S. Smedes' purchase of property, conversion to boarding house for female students

1880* Siding on house first horizontal then board and batten on rear

1880-95 East additions built using both wire and cut nails. Neo-classic porch present on house

1901 Law office moved off property

1905 House moved off property

1911 Fire at house, house returned to site, ell not moved but shed rear porch moved, dormer removed, new roof, neo-classic porch present, stovepipes in roof, no chimneys, second floor hall closed, no shutters present, new contrasting color paint, rear door in west room not present

1914-24 Brick chimney built on east end, rear porch enclosed with windows, grounds landscaped then subject to Department of Agriculture of Sam Houston State University activities

1925 Fire, erosion of grounds, no chimney on west end, stovepipe visible

1927-29 Neo-classic porch removed, second floor hall reopened, rear additions built, stone chimneys built on east and west ends and on east end of rear addition, new interior wall boards, new floor joists and flooring in west upstairs room

1930-36 Stone chimneys on house removed and replaced with brick, probable removal of chimney on east addition, removal of stone yard fence to be replaced by a picket fence, considerable landscaping 
1956-60 Neo-classic porch rebuilt, wooden shutters added, spring covered, pond expanded

1960-78 Air conditioning added, interior board and batten siding placed in upper rooms with insulation. Gas line added, sprinkler system added, electrical lines added, pond cleaned, dammed, channel dug on west side of pond, filling of yard

1979 Archeological investigations in May, September and October by James E. Corbin of Stephen F. Austin University and by Prewitt and Associates, Inc. Installation of burglar alarm line from northeast corner of yard to southeast corner of front porch.

*Approximate date 


\section{ARCHEOLOGICAL STRATEGIES}

The principal goals of the project were relatively limited: to find architectural evidence relating to the original structure. Initially the strategy was to open moderately large ( 1 x 2 meter) areas adjacent to the present house structure. Four pits were excavated in $20 \mathrm{~cm}$. levels; two from the chimneys to the front corners, one at the join of the porch to the house and one at the side of the addition to the rear of the structure. None of these pits revealed information relating to the original house.

A metal detector survey was made of the property in an attempt to locate nail fall around any earlier structures. Three pits were placed in an area of intense magnetic activity; numerous late 19th Century artifacts and features were noted. Subsequent strategy involved following the features to define major architectural patterns. (Fig. 2). The 1 x 2 meter units and $20 \mathrm{~cm}$. levels measured from the southeast stake were used throughout for statistical control except in minor instances. Test pit 35 was a 1 x 1 meter pit and the lower portions of Test Pits 37, 38 and 40 were excavated so as to separate the sealed floors from the levels above. The excavated material was passed through a $\frac{1}{4}$-inch mesh screen, and the artifacts from each unit and level were collected in appropriately labeled bags. Pits were numbered in their order of excavation and placed in northsouth or east-west orientations (as the situation demanded) based on a grid oriented $10^{\circ}$ east of magnetic north. The orientation of the grid is the same as that of the kitchen which was initially assumed to be similar to the original house (this assumption was subsequently found to be erroneous). 
Figure 2. General site and excavation photographs

a. The front facade of the Sam Houston house as it appeared in 1979 during the excavation project. The house faces north.

b. The west wall and floor of Test Pit 2 illustrating disturbances of concrete chimney foundation (left), electrical trenches (center) and concrete foundation pier (right).

c. Test Pit 10 south wall showing upper fill zone, intermediate medium brown sandy loam and dark brown midden over the light tan floor. A post mold appears in the cut in the floor of the unit.

d. Test Pit 41 looking south at brick foundation elements and sill fragment at left side of the pit.

e. Test Pit 43 looking south at sill in midground and brick foundation fragments.

f. Test Pit 38 west end indicating an upper fill zone, a medium brown sandy loam, dark brown midden, superimposed floors, basal light tan sandy loam and a pit on the left side of the unit. 
Figure 2

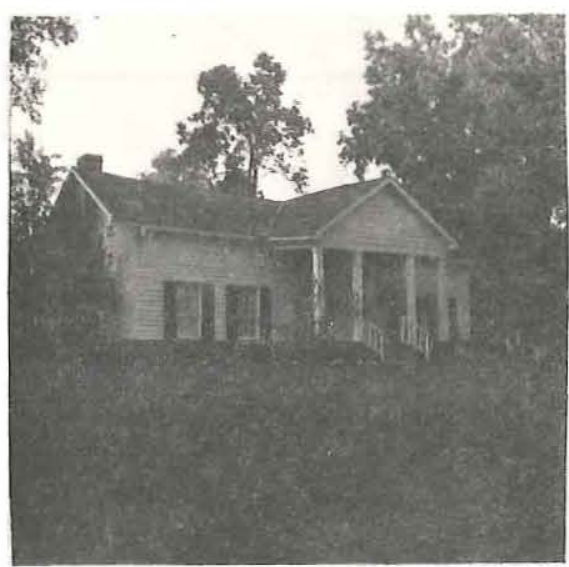

a
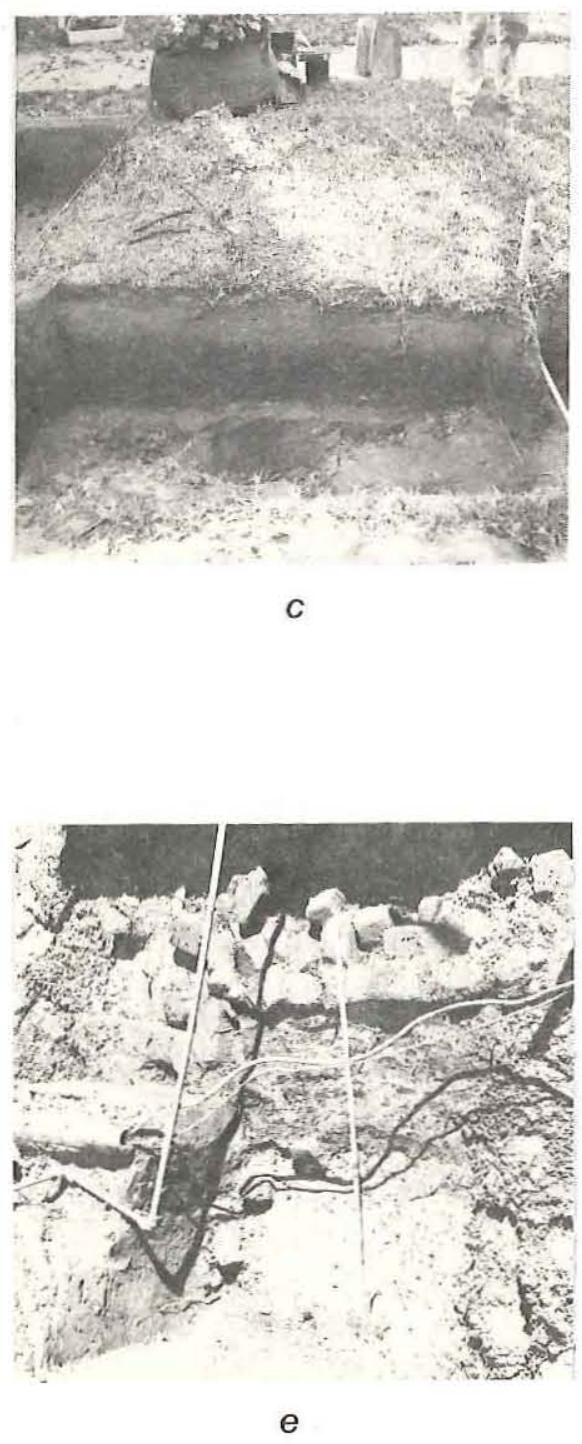

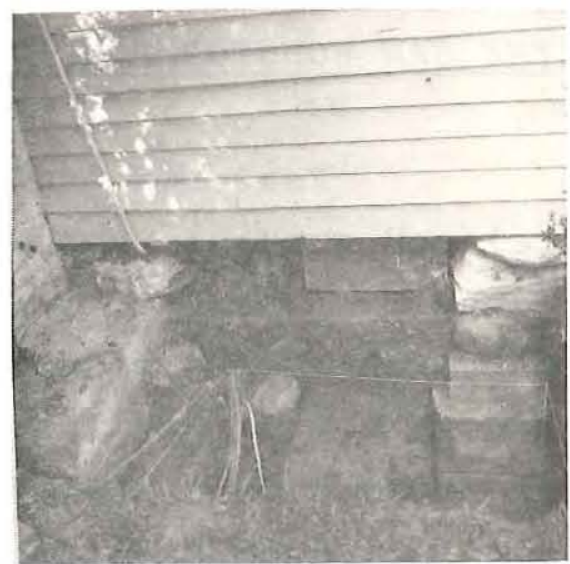

b
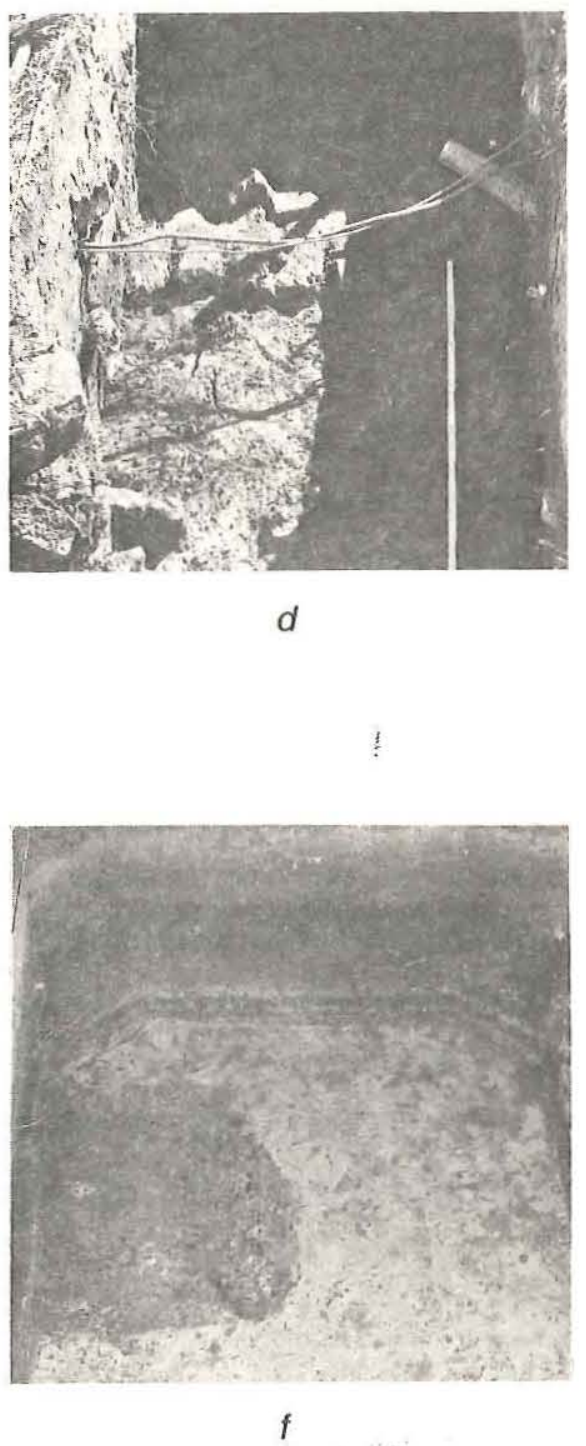
Features generally fell into one of two timerelated groups: early and modern. The early features consist of post molds or post holes, floors, foundations, etc., while the modern features comprise P.V.C. sprinkler lines, P.V.C. gas lines, electric lines and concrete piers or foundations. All features were recorded.

Recording techniques included plan and profile drawings of all pits (except floor plans where there were no features), photographs, notes on each unit and level within each unit excavated indicating soil texture, color and relative abundance of artifacts or other material, and a daily journal of events occurring on the site. Additional notes include a list of elevations, checklist of profiles and plans of the site indicating test pit locations.

As stated earlier, the placement of units was determined by following patterns of features, particularly post hole alignments and brick foundation alignments. It was felt that this technique would be more productive of architectural information than a sampling strategy or intensive excavation of artifact-bearing areas (Fig. 3).

SOILS

The natural sequence of deposits at the Sam Houston house site consists of two recognized components of Neogene age deposits and more recent colluvium and fills. The stratigraphically lowest deposit recognized is a yellow to yellow-orange sandy clay which is very dense. Overlying this is a deposit of light tan sandy loam genetically derived from the clay. The thickness of this zone varies 
from 0-35 cm. and averages about $20 \mathrm{~cm}$. The sandy loam deposit appears to be thinnest on the southwest corner of the house and thickest northeast of the house.

Above the natural deposits is a medium to dark brown sandy loam containing numerous artifacts. This zone is the undisturbed occupation midden. It varies in color and artifact frequency depending on the proximity of the post hole alignment, the proximity of major openings in the original structure and proximity to the brick footing wall. Away from the major structures, it is difficult to discern this zone which averages about $15 \mathrm{~cm}$. thick.

Located above the midden is a medium brown sandy loam containing a mixed assortment of artifacts and which appears to be plow zone mixed with fill. At the interface of this zone and the midden zone below, north-south oriented plow gouges were observed in Test Pits 37,38 and 40 . This zone averages $30-35 \mathrm{~cm}$. thick.

The uppermost zone is a shallow zone of clay or sand fills and mulches generally having a depth of 2-5 $\mathrm{cm}$. These fills are of recent origin. Test Pits 2-4 contain virtually only fills above the light tan sandy loam.

\section{ARCHEOLOGICAL FEATURES}

During the excavations a number of nonnatural disturbances of the depositional sequence were encountered. All of these were manmade. There are, however, a number of items which are of modern, late 20 th Century origin which are not included with the archeological features. The archeological features are soil disturbances such as post 
Figure 3. Plan of structures, excavations and features 


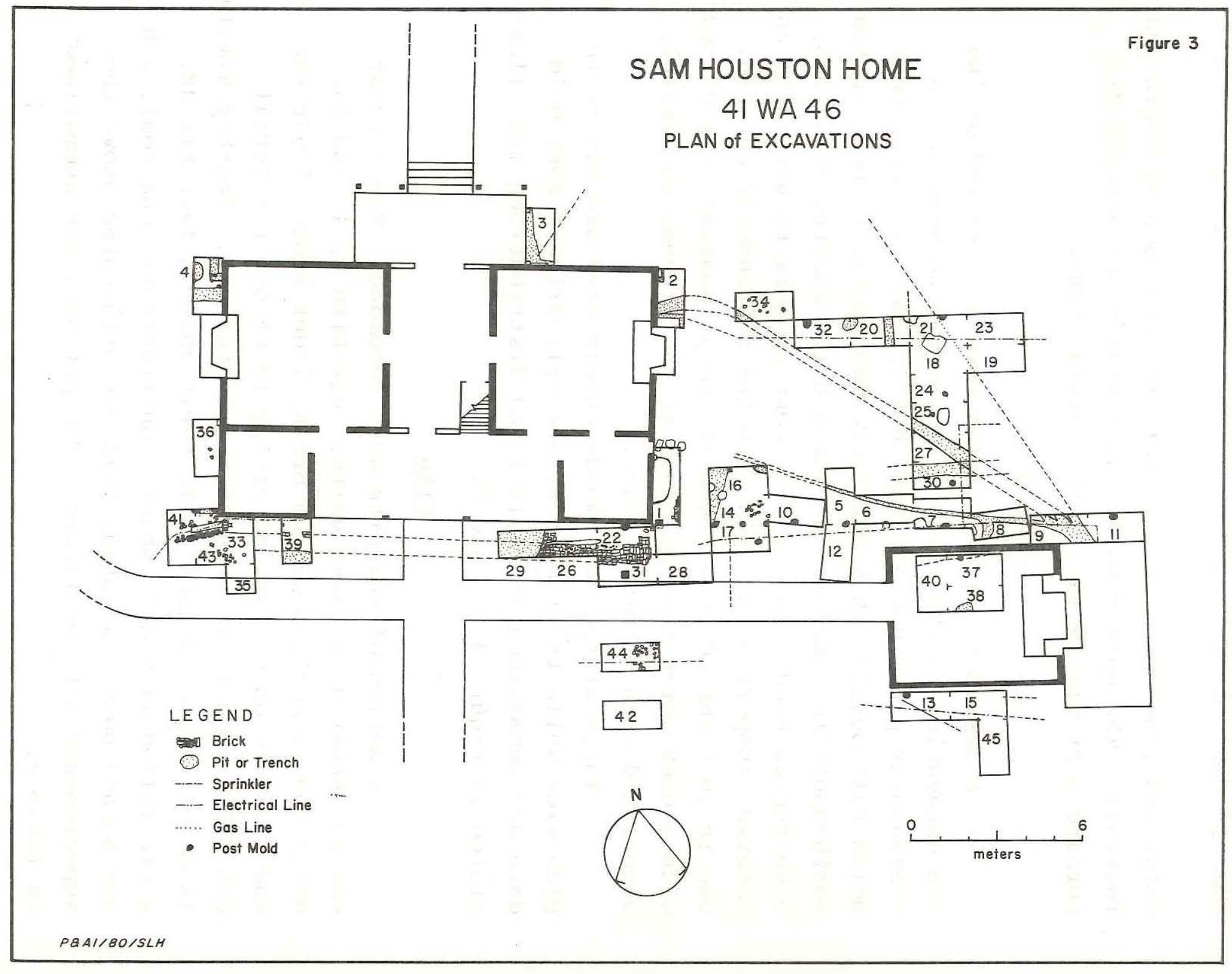


molds and trenches or structural elements such as piers and footings. The nonarcheological features are natural disturbances or mid to late 20 th Century items.

\section{Post Molds}

A series of 24 post molds were encountered during the excavations. They tend to be mainly grouped into a rectangular pattern measuring $10 \times 7.2$ meters. Five post molds fall outside this pattern. Two appear to be oriented north-south in association with a brick scatter which may have represented a back porch. One appears to have been an interior support associated with the rectangular pattern, one is just outside the south alignment possibly associated with a back porch and one south of the kitchen is possibly associated with a former fence.

Three of the post molds encountered are square in plan view while the remainder are cylindrical. Post mold data are summarized in Table 1 and distributions are illustrated in Figure $4 a, b$ and $d$.

\section{Pits}

A series of ten pits were recorded. The largest was encountered in three units, Test Pits 1,14 and 16. Other than a mottled medium brown, light brown, light tan and yellow-orange clay, no artifacts or other material could be recognized associated with the pit. Another similar large pit was excavated in Test Pit 29. In Test Pit 38, a pit filled with cast sheet iron fragments, charcoal, ash and burned bone was noted; this pit originated above the superimposed kitchen floors. The pit data are summarized in Table 2 . 
TABLE 1

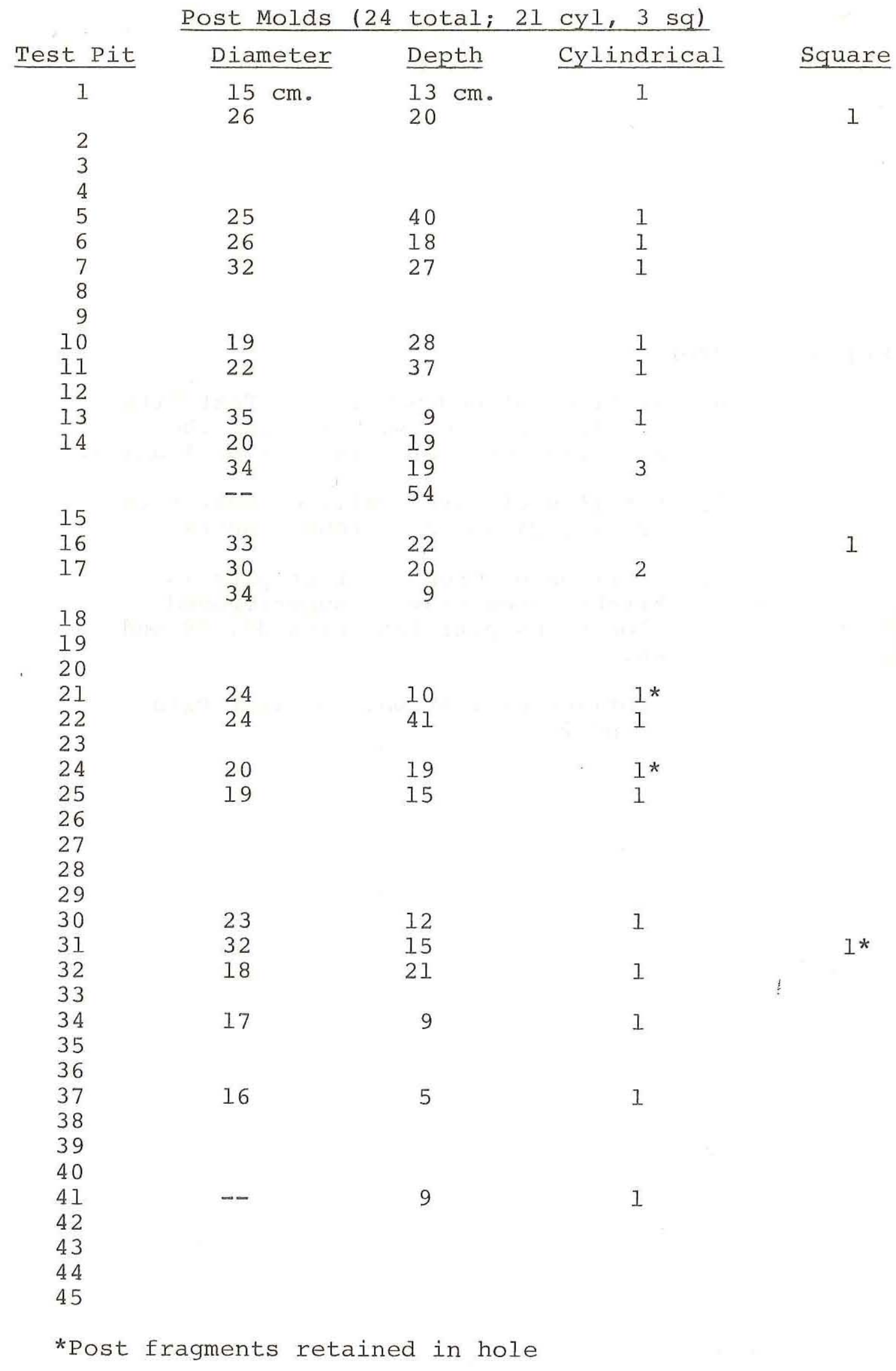


Figure 4. Profiles

a. Profiles of south walls of Test Pits $1,14,10,5,6$ and 7 showing the alignment of post molds; Group I units.

b. Profiles of north walls of Test Pits $32,20,21$ and 23; Group I units.

c. Profiles of Group IV test pits in kitchen area showing superimposed floors and pit; Test Pits 37,38 and 40 .

d. Profiles of west wall of Test Pits 1 and 2 . 


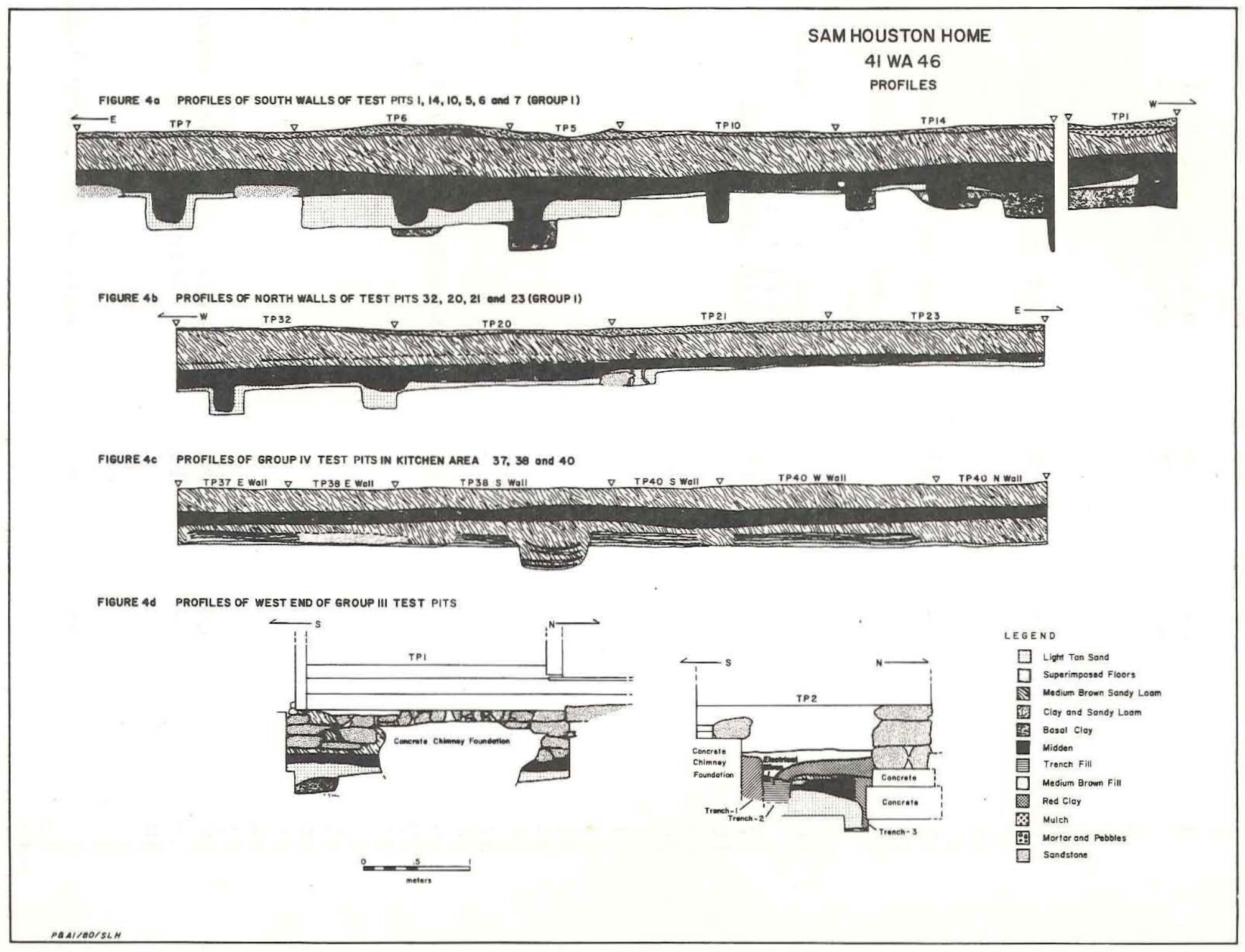


TABLE 2

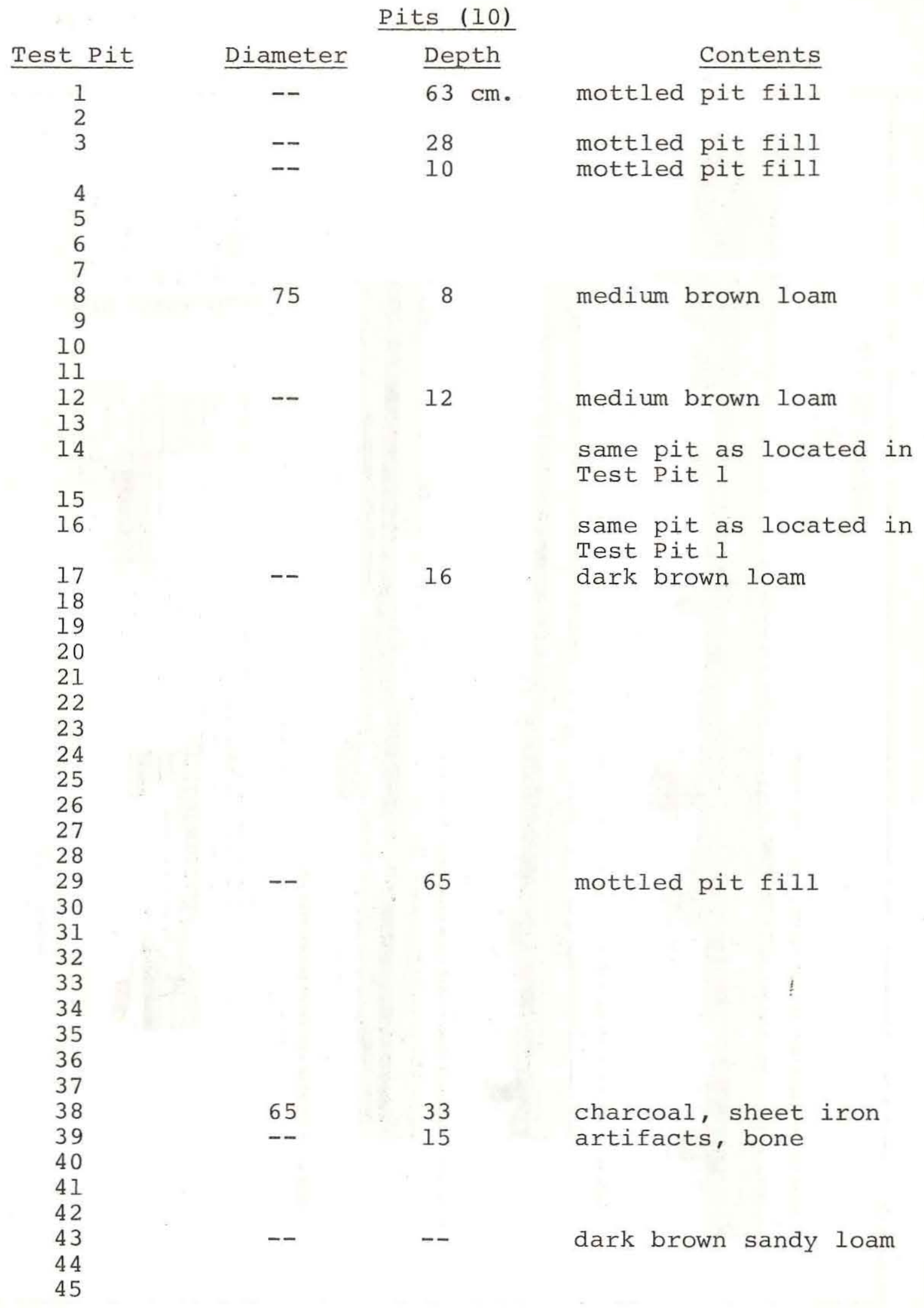




\section{Trenches}

A series of trenches representing a variety of functions was recorded. Virtually all of them are of 20 th Century origin and most were probably dug within the last 15 years. A small number of the trenches are footing trenches associated with concrete piers and chimney pads; these originated at the time the house was relocated on the site. The remaining trenches consist of air conditioner piping, P.V.C. tubing of gas and sprinkler systems and trenches for buried electrical lines. Generally, sprinkler trenches could not be recognized because of their shallow depth in disturbed deposits. The only early 20th Century trench was associated with a cast iron galvanized water pipe encountered in Test Pit 30. Details on the trenches are summarized in Table 3.

\section{Sill Beams}

Two segments of sill beams were encountered south of the present structure and adjacent to the additions. One segment was encountered in Test Pit 26 with very small fragments observed during the excavation of Test Pit 22 . The beam is 35-40 cm. wide on the west end and is about 17 $\mathrm{cm}$. wide on the east end. The decrease in width appears to be attributable to erosion along its southern edge. The sill beam segment in Test Pits 26 and 22 rests directly upon a square brick pier and parallels a brick foundation wall (Fig. 5).

In Test Pits 33, 41 and 43 a similar sill segment also rests on a ca. $40 \mathrm{~cm}$. square brick pier, but the west end appears to be displaced to the south. The footing wall of the structure also appears displaced. Only the basal portion of the beam remains. 
TABLE 3

\section{Trenches}

\begin{tabular}{|c|c|c|c|}
\hline Test Pit & Width & Depth & Contents \\
\hline 1 & $60 \mathrm{~cm}$. & $45 \mathrm{~cm}$. & electric lines; insulated wire \\
\hline 2 & 12 & 30 & chimney footing \\
\hline & & & footing pier (concrete) \\
\hline 3 & 25 & 26 & footing pier \\
\hline 4 & 30 & 35 & air conditioning pipes \\
\hline & 26 & $40+$ & footing pier \\
\hline & 55 & 35 & electric lines \\
\hline 5 & 26 & 65 & electric lines (A) \\
\hline 6 & & & same electric line trench \\
\hline 7 & & & same electric line trench \\
\hline 8 & & : & same electric line trench (A) \\
\hline 9 & 72 & 65 & $\begin{array}{l}\text { electric lines (C); air } \\
\text { conditioning; gas line (B) }\end{array}$ \\
\hline 10 & & & \\
\hline 11 & & & \\
\hline 12 & & & \\
\hline 13 & -- & 45 & water line \\
\hline 14 & & & \\
\hline 15 & & & \\
\hline 16 & & & same electric line trench \\
\hline 17 & & & \\
\hline 18 & -- & 45 & same gas line trench (B) \\
\hline 19 & & & \\
\hline 20 & & & \\
\hline 21 & & & same gas line trench (B) \\
\hline 22 & & & \\
\hline 23 & & & \\
\hline 24 & & & \\
\hline 25 & 50 & 40 & sprinkler (C) \\
\hline & 17 & 19 & sprinkler \\
\hline 26 & & & \\
\hline 27 & & & same sprinkler trench (C) \\
\hline 28 & & & \\
\hline 29 & & & \\
\hline 30 & 36 & 40 & electric cables \\
\hline & 50 & 24 & water pipe \\
\hline 31 & & & same sprinkler trench (C) \\
\hline 32 & & & \\
\hline 33 & & & \\
\hline 34 & & & \\
\hline 35 & & & same sprinkler trench (C) \\
\hline 36 & & & \\
\hline 37 & & & \\
\hline 38 & & & \\
\hline 39 & 20 & 15 & electric lines \\
\hline 40 & & & electric lines \\
\hline 41 & & & \\
\hline 42 & & & \\
\hline 43 & & & \\
\hline 44 & & & \\
\hline 45 & & & \\
\hline
\end{tabular}


The function of the sill beams was to support the floor joists at the inside edge of the bearing wall.

\section{Foundation Walls}

For the purposes of this report, foundation walls are the same as footings; that is, the subsurface wall which supports the bearing wall of the structure erected over it. Stone Foundation Walls:

Stone footings encountered in Test Pits 1, 22, 26, 39,33 and 36 were all associated with the additions constructed on the house after it had been returned to its present location. They consist of coursed sandstone rubble incompletely set in sandy lime mortar; much of the mortar has leached out leaving the wall supported on sandy loam. Wall height is generally about $35 \mathrm{~cm}$. but varies from $c a$. 30-43 cm. The thickness is unknown. Concrete is associated with the foundations in the Test Pits 26-29 junction over and with a chimney base in Test Pit 1. These walls are associated only with the enclosed additions and not the rear porch.

Brick Foundation Walls:

Associated with the sill beam and brick piers is a laid brick wall which averages $65 \mathrm{~cm}$. (26 inches) in width and is a minimum of three bricks high. They appear to have been laid as alternate courses of headers and stretcher. Few soldiers or horizontal soldiers were encountered and no evidence of mortar was seen.

The longest stretch of wall encountered was nearly four meters. No recognizable bonding pattern was used. All bricks encountered were soft sandy red-brown specimens 
Figure 5. Floor plans

a. Floor plan of the west end of Group III test pits showing sill beam and footings.

b. Floor plan of the east end of Group III units with sill beam, footings and post molds. 


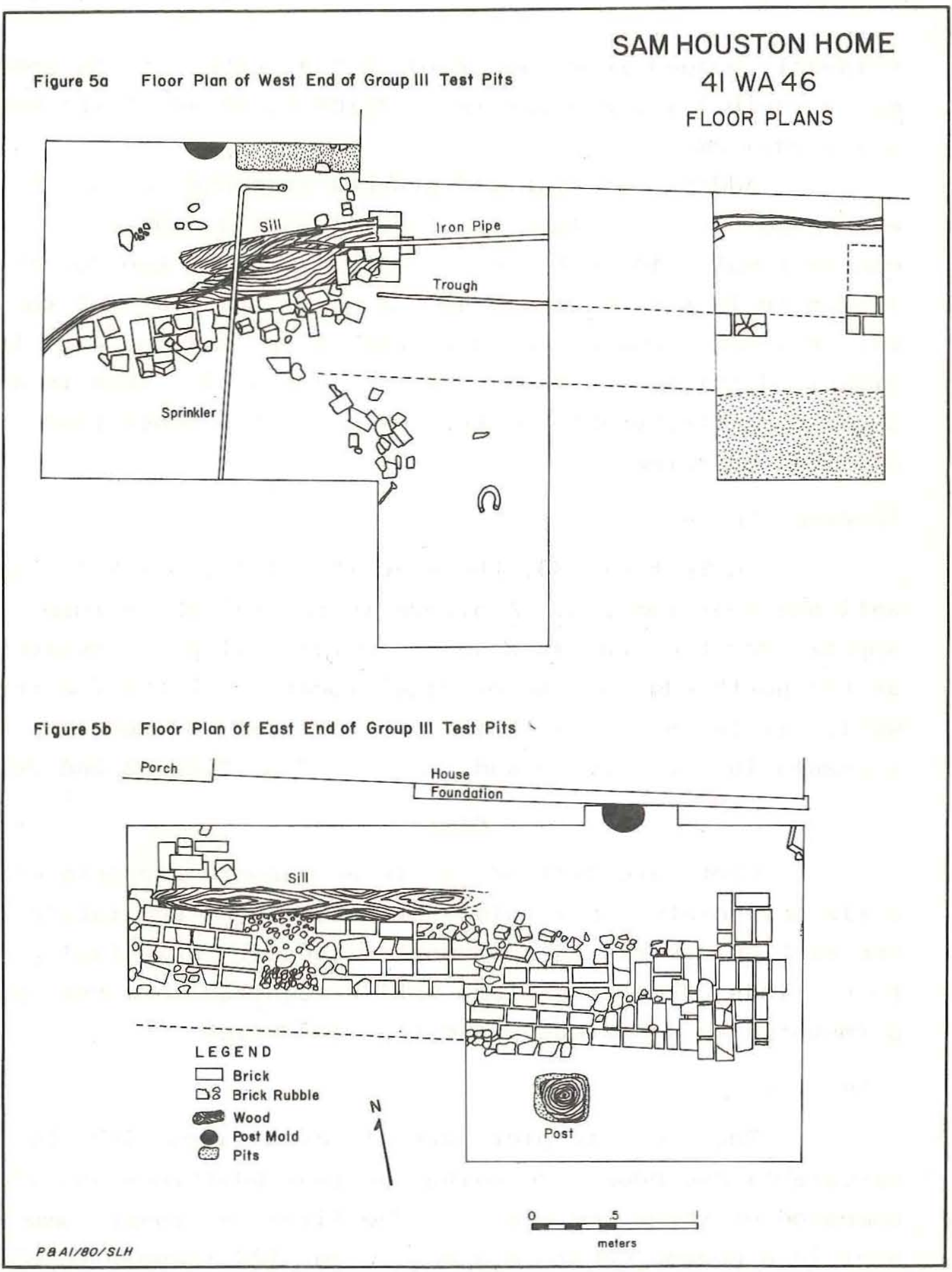


evidently molded in wooden molds and a number of the speciments exhibit fly ash glazing. Brick sizes are uniformly $9.7 \times 20.7 \mathrm{~cm}$.

Additional highly disturbed segments of this wall were encountered in Test Pits 39, 41 and 43. Only one brick course remains in Test Pit 39 while, in part, two courses remain in Test Pits 41 and 43. Much of the width of the wall has been removed in these test pits, and the wall is clearly displaced in Test Pits 41,43 and 33. This is almost certainly attributable to the moving of the house from its original position.

Footing Impressions:

In Test Pit 33, the majority of the brick footing wall has been removed. A groove in the tan sandy loam appears south of the $40 \mathrm{x} 40 \mathrm{~cm}$. brick sill pier apparent at the north edge of the original location of the footing wall. It is in line with the northern wall of the footing segments in Test Pit 39 and those in Test Pits 22 and 26.

\section{Piers}

Piers are defined herein as masonry supports of sills and joists. Post piers are considered separątely in the section describing post mold features. Essentially three kinds of masonry piers were recognized; concrete piers surmounted by sandstone, sandstone and brick.

Concrete:

The concrete piers are all associated with the re-established house excluding the rear additions and are composed of three components. The first and lower component is a poured concrete block $70 \mathrm{~cm}$. $(28$ inches) to $97 \mathrm{~cm}$. 
(38 inches) square and $30 \mathrm{~cm}$. (12 inches) high surmounted by a poured concrete block $50-70 \mathrm{~cm}$. (20-28 inches) square and 15-26 cm. (6-10 inches) high. A series of sandstone slabs is placed upon each of these to form the above grade aspect of the pier. These appear at the northeast, northwest, southeast and southwest corners and at the points at which the front porch joins the house.

Sandstone:

During excavation of the post mold alignments, five sandstone slabs were encountered. Their measurements average about 50-55 cm. square and 12-15 cm. thick (20-22 inches and 5-6 inches). Two were located on the east-west-southern post alignment at the east end and two were located on the north-south alignment east and near the middle and north ends of the alignment. The final stone, somewhat smaller, is located about one meter northwest of the most northerly of the larger piers and apparently in line with an east-west line of post molds at an elevation averaging 124.5 meters (408.5 feet) above mean sea level. It is assumed that because of their close association with the post mold alignments that these piers were used to replace decomposing pier posts.

Brick:

Elements of at least three brick piers or sleepers were encountered adjacent to the brick foundation-footing wal1. These piers consist of at least three courses of handmolded low temperature fired brick which exhibit a paste of red-brown sandy clay. Occasional segments of brick are coated with a fly ash glaze (kiln-gloss); this occurs when ash is caught in the kiln draft and is deposited on the 
exterior bricks in the stack.

The piers average $40 \mathrm{~cm}$. square and are composed of $21 \times 10 \mathrm{~cm}$. bricks which average $5 \mathrm{~cm}$. in thickness. All the piers consist of headers and stretchers with no attempt to establish a bonding pattern. The easternmost pier appears to be lacking elements along the east edge. Lying on top of the western two pier segments exposed are traces of a $40 \mathrm{~cm}$. wide squared log sill. It is assumed that the function of these piers was to support the sill which in turn supported the floor joists.

\section{Floors}

A series of superimposed earthen floors was encountered in three test pits excavated beneath the present kitchen structure. These floors all appear to be associated with the former mid-19th Century kitchen. The series lies on undisturbed light tan sandy loam of Neogene age.

The floors consist of the following sequence from top to bottom:

(1) light tan sandy loam interbedded with thin ash lenses and medium brown sandy loam (1-4 cm. thick)

(2) dark red-brown sandy clay (1-2 cm. thic̣k)

(3) ash lenses (1-2 cm. thick)

(4) dark red-brown sandy clay (1-2 cm. thick)

The average thickness for this series is about $10 \mathrm{~cm}$. They are clearest in the southern and western portions of the three units excavated in the kitchen area. They are diffuse along the north wall and may possibly indicate the edge of the original kitchen (Figs. $2 f$ and $4 c$ ).

Artifacts associated with these floors include numerous iron fragments which appear to have been burned, 
a small amount of ceramics including banded slipware, bones and glass. All of these floors contained ash and charcoal in addition to the artifacts.

\section{Chimney Foundations}

Three chimney foundations were examined in Test Pits 1, 2 and 4. All were concrete and 20 th Century in origin. The foundation in Test Pit 1 consisted of a $1.4 \times .6 \times .55$ meter concrete pad poured into a hand-excavated pit. This apparently was a part of the 1929 work on the house. No remnants of the chimney exist.

The remainder of the pads were concrete poured into wooden forms as bases for the present hard fired brick chimneys. The footing trenches extend about $20 \mathrm{~cm}$. beyond the concrete pad. In turn, the concrete extends $40 \mathrm{~cm}$. beyond the chimney exterior. The depth of the concrete pad is about $43 \mathrm{~cm}$. The pads measure $43 \times 110 \times 200-300 \mathrm{~cm}$.

\section{NONARCHEOLOGICAL FEATURES}

A variety of modern and natural phenomena are included in this brief section.

\section{Worm Tubes}

Earthworms, June beetle larvae and insect holes account for considerable soil disturbance. The soft friable soil with a high organic content is an ideal habitat for such creatures. Worm tubes were readily recognizable especially in areas where the tubes passed through different colored zones. It is estimated that $80 \%$ of the deposits have been relocated by these activities. 


\section{Rodent Runs}

It is surprising that only one rodent run was recognized. This was in the eastern half and east wall of Test Pit 38 above the superimposed kitchen floors.

\section{$\underline{\text { Root Casts }}$}

One root cast was observed which extended through a post mold in Test Pit 11. Other root molds or casts were encountered in Test Pit 41 at the interface of the base of midden deposits and the undisturbed clay.

\section{Plow Zone}

Universally present in all units excavated, this ca. $40 \mathrm{~cm}$. thick zone of disturbed light to medium brown sandy loam overlies dark to medium brown undisturbed midden. The plow zone contains a mixture of artifacts which date from the early to mid-20th Century. It almost certainly stems from the Sam Houston State University Agriculture Department activities on the site.

\section{Sprinkler Lines}

Present in many of the test pits were P.V.C. tubing of a recent lawn sprinkler system. This system is oriented on a north-south grid with the lines about 6.5 meters apart. The sprinkler lines were placed approximately 20-25 cm. below the surface.

\section{Water Lines}

An early water pipe was encountered in a trench oriented east-west in Test Pit 30; the pipe is galvanized cast iron about $4 \mathrm{~cm}$. in diameter and exhibited very thick oxidation. Another similar line was noted running at a 
diagonal in Test Pit 13 (but not in Test Pit 45); it terminated in a "U" joint which was oriented vertically. The remaining water line was a copper line found in the east end of Test Pit 15 and which was connected to a faucet in current use.

\section{Gas Line}

A $7.6 \mathrm{~cm}$. diameter P.V.C. gas line was encountered in Test Pits 9, 18 and 21. It was placed about $23 \mathrm{~cm}$. below the surface.

\section{Electrical Lines}

Numerous electrical lines were noted. One parallel set of lines extended from Test Pit 2 at the northeast corner of the present house location through Test Pits 34, 25, 27, 30 and 9. Another extended from Test Pit 16 through 5, 6, 7, 8 and 9 to join the first set. An additional line was encountered in Test Pits 41,43 and 33. The first set of lines was laid directly into the trenches. The second set was laid in a galvanized iron $2.54 \mathrm{~cm}$. diameter pipe while one last set was partially enclosed in pipe and the remainder simply laid in the trench.

\section{Air Conditioner Pipes}

Insulated air conditioner lines were encountered in Test Pits 2, 4 and 9; these were associated with nearby air conditioner pads.

\section{Sidewalks}

At the kitchen entrance, at the rear of the house and at the front entrance to the house were recent hand fired brick walks set with Portland cement mortar on a $3 \mathrm{~cm}$. 
thick bed of sand. These were included in part in Test Pits 28, 31, 39, 33, 35, 41 and 43 as the uppermost component which had to be removed so that the units could be excavated. Brick brands (produced from the l880s to the 1940s [Kelley and Kelley 1979: 84]) include the following: STANDARD, DIAMOND, COLE, WHITE BELLE CHERRY REDS CORSICANA and H.B.\&C. Co. as well as bricks with a pressed rectangular panel.

\section{SUMMARY OF FEATURES}

Four sets of horizontally discrete feature associations have been identified on the basis of location, type and artifact associations. The first group is composed of piers, trenches and pits associated with renovation of the house after it was returned to the site. They comprise air conditioning, electrical, sprinkler and footing trenches, and the artifact associations are modern. This pattern is associated with all four sides of the present house location.

A series of post molds and sandstone piers is included within the Group II features and appear to represent the remains of extensive late 19th Century additions. One trench is possibly associated with these post molds; this feature is an old galvanized water line trench which extends east-west through Test Pit 30 .

Features in the Group III units consist of brick alignments, sill fragments, associated depressions, brick scatter and post molds which probably represent the rear wall foundation of the original log house. The sill beam fragments are almost exactly the same size as the front sill of the existing house. The fragments probably represent 
the rear beam which was set on brick piers with an exterior wall. Alternatively, the sill could be the front sill and the wall could be the joist sleepers similar to the sleeper walls at San Fernando Cathedral in San Antonio (Fox, Scurlock and Clark 1977: Fig. 8, Fig. 16, p. 17). Group IV features comprise superimposed mid-19th Century dirt kitchen floors and a later intrusive pit. Group $V$ units produced only one post mold.

\section{ARTIFACT DISTRIBUTION}

The provenience table (Table 4) indicates that a substantial majority of the 20 th Century artifacts were distributed within the excavation units adjacent to the present location of the house and surrounding Test Pit 9. These areas have undergone significant disturbance as a result of air conditioner installation and house renovation activities. With the exception of a disturbance in Test Pit 29, which is also apparently related to modern renovation, all other modern artifacts occur within the upper 20 $\mathrm{cm}$. of the deposits or within the fill of modern utility trenches such as the one passing through Test Pits 34, 25, 27 and 9, and the one passing through Test Pits 16, 5, 6, 7, 8 and 9. The modern disturbances, then, are both horizontally and vertically limited in their extent and are separable from earlier deposits at the site.

Late 19th Century and early 20th Century artifacts are widely distributed both horizontally and vertically. A part of the vertical mixing appears to have occurred during the time the site was subjected to plowing shortly after the turn of the century. However, undisturbed 19th Century 
midden deposits are encountered at a depth of about 30-45 $\mathrm{cm}$. below the present grade. Artifacts found in the Group II test pits are interpreted as representing the postHouston occupation of the site. These artifacts primarily consist of school and female-related items which support archival evidence that the house served as a girls' boarding house during the latter part of the 19th Century.

Mid-19th Century artifacts are not especially common in any of the areas excavated but are slightly more numerous in the existing kitchen area and at the rear of the present house. This second area coincides with the structural evidence which suggests this was the rear of the original house before additions were made. It should be noted that these artifacts are stratigraphically low in the deposits in all areas of the site where they were encountered.

Few artifacts could be associated with specific features. However, a number of artifacts were encountered in the sealed kitchen floors (underneath the existing kitchen) which are mid-19th Century in origin; these date the kitchen to the Houston period of occupation and confirm the essential spatial relationships of the house to the kitchen.

\section{SUMMARY OF ARTIFACTS}

\section{A large number of artifacts were recovered from} the site. The late 20th Century artifacts are principally synthetic materials associated with air conditioning and other modern services, and with the renovation of the house. They are virtually all construction-related although a 
small group is related to the tourist function of the site. These latter items include ring pull tabs, drink cups and the like.

A majority of the artifacts are architecturerelated materials which primarily include nails and windowpane sherds. This is to be expected if it is assumed that South's (1977) Frontier Pattern of artifact frequency (a high proportion or percentage of architecture-related artifacts such as nails) as opposed to his Carolina Pattern (a high proportion or percentage of kitchen-related artifacts such as bones, ceramics, cooking utensils) is an appropriate model to apply to this site. These artifacts are associated with a set of features, principally post molds, which are assumed to represent late 19th Century additions to the primary structure.

Iron artifacts were numerous and consist mostly of nails. These materials indicate a wide range of activities and functions. Equestrian artifacts, door hardware and kitchen-related items are present in small numbers. Buttons, buckles, toy fragments are relatively common. Ceramic artifacts included a few decorated dinnerware sherds; overall, the number of ceramics is relatively small and the total number of decorated sherds compose a minute percentage of the artifact sample. Glass artifacts were numerous with lamp chimney and windowpane fragments accounting for a vast majority of the sherds. Patent medicine or drugstore bottles were the most common bottle form.

Other minor categories of artifacts included a large number of personal items, primarily clothing fasteners and scholastic artifacts, and a small number of toys. 
The distribution of animal bones, coal and slag are suggestive of specific disposal patterns. The bone frequency was high in the vicinity of the kitchen while coal and slag were most common in the areas of Test Pits 14 and 16, and 27 and 30. It is probable that these latter two areas were near coal-burning stoves.

\section{INTERPRETATION OF ARTIFACTS}

The large number of artifacts recovered from the site posed difficult logistical problems during analysis. The recent 20th Century artifacts will not be discussed further since the documentation of that portion of the history of the site is relatively good.

Numerous architectural artifacts were encountered which date to the late 19th and early 20th Centuries and are associated with the post-Houston occupation. Many cut and wire nails were present and suggest a pre-1880 construction date for the additions which subsequently required a considerable amount of repairs. Apparently indoor water was added to the east side early in the 20 th Century. Large numbers of clothing fasteners and smaller numbers of costume jewelry, doll parts, miniature ceramics, marbles and other toys indicate a predominantly female occupancy of the additions with a lack of smoking pipes, snuff and liquor bottles, men's clothing buttons and other male-oriented items.

Numerous slate fragments, slate pencils, pen nibs and so forth indicate school-age children which, with the other artifacts, suggest a dormitory situation. The artifacts are in many ways similar to those encountered 
at Ursuline Academy in San Antonio (Clark 1974 and Katz 1977); the primary differences are a lack of the religious artifacts noted at Ursuline and the presence of costume jewelry such as rings and pendants.

The patent medicine bottles, drugstore bottles, ink bottles, castoria and cod liver oil bottles add to the conclusions concerning the nature of the occupancy. There seems to be little doubt that the additions to the original Houston house served as a young girls' dormitory where an older person (as suggested by the denture fragments) served either as a chaperone or a dorm parent.

The general economic level represented cannot be considered to be very high. Few decorated ceramics are present; in proportion to other artifacts, there are even fewer of these items than are found at U.S. military sites such as Fort Lancaster (Clark 1972, Black 1976, Hays and Jelks 1966), Fort Griffin (A. Fox 1976) and Fort Richardson (Westbury 1976 and Dickson and Westbury 1976). The jewelry noted at the site is obviously inexpensive. This suggests an austere environment during the boarding house phase of occupation in which frills were frowned upon.

Nonartifact faunal remains indicate a variety of foods which included beef, chicken, clams, oysters and fish were eaten. Few cans, pickling jar fragments, and similar items were observed in the collection. This suggests that much of the food supply may have been grown in a garden or was obtained from locally-grown sources.

A relatively small number of artifacts could be assigned to Houston's period of occupation. Among the artifacts assignable to this period were certain ceramics (banded slipware, stencilware, spatterware and certain of 
the transfer printed sherds) and bottle sherds (brown or amber whiskey bottles, wine bottles). In general, however, as scarce as artifacts are for this period, there are more decorated sherds and costly liquors which indicate a much higher economic status for that phase of occupation than is evident during the later phases.

For a complete description of the artifacts, see Appendix I.

\section{CONCLUSIONS}

The 45 test pits excavated at the Sam Houston house site have documented a wide variety of features, activities and other cultural data. It is clear that the present location of the house is not exactly coterminus with the original house location. The original house sills were placed on brick piers three to four bricks high with a brick wall either outside the house wall line or as a sleeper support for floor joists. Intact deposits pertaining to the Houston occupation exist to the rear and possibly beneath the southern one-half of the present house.

Evidence of moving activities are clearly present on the west end of the original house foundation and in brick scatter noted in other areas. Evidence of one contemporary outbuilding, the kitchen, was found beneath the present reconstructed kitchen. The evidence consists of several thin superimposed floors containing a small number of artifacts. It is obvious that much more of the kitchen remains intact and undisturbed beneath the present structure but not south or north of it.

Evidence for post-Houston occupation lies east of the present structure and is composed of an arrangement of 
13 post molds and four sandstone piers with associated late 19th and early 20 th Century artifacts. These artifacts, other than the architectural ones, indicate a girls' dormitory very similar to that encountered at Ursuline Academy in San Antonio which was another girls' dormitory.

An examination of historic photographs and the plat of features suggest that not all of the architectural features of the late 19th Century additions were encountered; this precludes a complete delineation of the additions. The economic level seems to have diminished even though a large number of artifacts are present. The later period of occupation was much longer than the Houston occupation, and this is reflected in the numbers of artifacts recovered.

Except for the kitchen, no outbuildings were

located nor was any attempt made to locate others; this was in keeping with the assigned mission which was to explore the architectural potential of deposits near the house. It was demonstrated, however, that in areas near and away from the present house there are undisturbed historic deposits which span the entire range of occupation at the site from Houston's time to the present use of the site as a museum.

\section{RECOMMENDATIONS}

Although the present alignment of the Houston home is not precisely upon the original location, the differences are relatively minor. The expense of adjusting the location of the structure and the potential damage to apparently intact 19th Century archeological deposits are such that it is recommended that the existing building alignment not be altered. 
Direct archeological evidence of the nature of the original porch (if, indeed, it existed during Houston's tenure) and the original chimneys were not encountered during the excavations. The subsurface indications are that any archeological remains of these features have been destroyed as a result of various activities which occurred after the Houston era. It is suggested that intensive examination for architectural evidence for these features be made during the planned restoration of the structure. If attempts are made to reconstruct a detached kitchen which reflects a close approximation of the Houston era structure, then it is recommended that extensive archeological excavations precede these endeavors. Subsurface indications suggest that substantial remains of the original kitchen exist and further excavations can potentially provide the dimensions, structural details and layout of that building.

In the event that it becomes desirable to reconstruct other outbuildings such as the servants quarters and the latrine, it is recommended that further archeological excavations be undertaken to locate any remains of those structures in order to provide as much structural data as can be obtained. A side benefit from this may result from excavations of the latrine; it has been well established that artifacts are generally better preserved in latrines and these materials may provide a more complete view of the lifestyles at a given period of time.

A general recommendation is made regarding subsurface modifications which may ensue during future landscaping and restoration activities at the site. These should be preceded by archeological excavations since the current work has demonstrated that these well-intentioned activities 
can result in the destruction of significant subsurface data relating to the past use of the site. Particularly sensitive in this respect are the areas south and east of the present structure location where substantial 19 th Century materials appear to be preserved. Any such investigations may be partially funded through the Grants-in-Aid Program of the National Register of Historic Places.

Interpretive displays using the artifacts recovered during the current excavations are encouraged. These items may be used to illustrate changing lifestyles and functions associated with the Houston home through the many years of its existence. In place exhibits of the original structural remains along the south side of the existing house location are not recommended. The difficulties of stabilization and protection of these remnants argue against this type of display, even though it would probably be quite popular with museum visitors. 
REFERENCES CITED

Alexander, Drury Blakeley and Todd Webb

1966 Texas Homes of the Nineteenth Century. The University of Texas Press. Austin.

Barker, Eugene and Amelia Williams (eds.)

1941 The Writings of Sam Houston, 28Z3-2863, Vol. VI.

The University of Texas Press. Austin.

Bell, Wayne, John Klein and David Hoffman

1975 Preservation and Development Plan for the Sam

Houston Memorial Museum. Prepared for Sam Houston

State University by Bell, Klein and Hoffman,

Architects and Restoration Consultants. Austin.

Black, Art

1976 Fort Lancaster: Spring 1974. Archeological Report No. 28, Historic Sites and Restoration Branch, Texas Parks and Wildlife Department. Austin.

Bolton, Herbert Eugene

1970 Texas in the Middle Eighteenth Century: Studies in Spanish Colonial History and Administration. The University of Texas Press. Austin.

Bureau of Navy Personnel

1972 Basic Construction Techniques for Houses and Small Buildings Simply Explained. Dover Publications, Inc. New York.

1973 Tools and Their Uses. Dover Publications, Inc.
New York.

Campbell, Hannah

1964 Why did they name it. . ? Ace Books. New York.

Carr, John T., Jr.

1967 The Climate and Physiography of Texas. Report 53, Texas Water Development Board. Austin.

Carter, Emily Suzanne and Crystal Sasse Ragsdale

1976 Biegel Settlement: Historic Sites Research, Fayette Power Project, Fayette County, Texas. Research Report No. 59, Texas Archeological Survey, The University of Texas at Austin. 
Clark, John W., Jr.

1972 Archeological Investigations at Fort Lancaster State Historic Site, Crockett County, Texas. Research Report No. 22, Texas Archeological Salvage Project, The University of Texas at Austin.

1974 Archeological Excavations at Ursuline Academy, San Antonio, Texas, June 1974. Office of the State Archeologist Special Report, Texas Historical Commission. Austin.

1975 The "Digs" at Fort Lancaster, Texas, 1966 and 1971. Military History of Texas and the Southwest 12(4): 283-300.

Clifton, Robert T.

1970 Barbs, Prongs, Points, Prickers, and Stickers: A Complete and IlZustrated Catalogue of Antique Barbed Wire. University of Oklahoma Press.

Cushion, J.P.

1959 Pocket Book of English Ceramic Marks and Those of Wales, Scotzand and Ireland. Faber and Faber. London.

Davis, William B.

1974 The Mammals of Texas. Bulletin 4l, Texas Parks and Wildlife Department. Austin.

de la Peña, José Enrique

1975 With Santa Anna in Texas: A Personal Narrative of the Revolution. Texas A\&M University Press. College Station.

Dickson, D. Bruce and William Westbury

1976 Archeological Research at Fort Richardson State Park, Summer 1975. Report No. 28, Anthropology Laboratory, Texas A\&M University. College Station.

Dinkin, Milton, Irwin Cohen and Robert Morton

1974 The Official Black Book of United States Coins. House of Collectibles. New York.

Fisher, W.L., C.R. Chelf, C.A. Shelby, L.E. Garner, D.E. Owen, and D.A. Schofield

1965 Rock and Mineral Resources of East Texas. Report of Investigations No. 54, Bureau of Economic Geology, The University of Texas at Austin.

Forney, Matthias N.

1974 The Railroad Car Builder's Pictorial Dictionary. Dover Publications, Inc. New York. 
Fournier, Robert

1973 IZZustrated Dictionary of Practical Pottery. Van Rostrand Reinhold Co. New York.

Fox, Anne A.

1976 Archaeological Investigations at Fort Griffin State Historic Park, Shackelford County, Texas. Archaeological Survey Report, No. 23, Center for Archaeological Research, The University of Texas at San Antonio.

Fox, Daniel E., Dan Scurlock and John W. Clark, Jr.

1977 Archeological Excavations at San Fernando Cathedral, San Antonio, Texas: A Preliminary Report. Office of the State Archeologist Special Report 22, Texas Historical Commission. Austin.

Friend, Llerena B.

1954 Sam Houston: The Great Designer. The University of Texas Press. Austin.

Gould, F.W.

1969 Texas Plants: A Checklist and Ecological Summary. Texas Agricultural Experiment Station, Texas A\&M University. College Station.

Hamilton, Henry $W$. and Jean Tyree Hamilton

1972 Clay Pipes from Pamplin. The Missouri Archaeologist $34(1-2): 1-47$.

Hays, T.R. and Edward B. Jelks

1966 Archeological Exploration at Fort Lancaster, 1966: A Preliminary Report. Report 4, State Building Commission Archeological Program. Austin.

Jackson, Marsha F.

1977 Texana: Excavations at a Nineteenth Century Inland Coastal Town, Jackson County, Texas. Research Report No. 56, Texas Archeological Survey, The University of Texas at Austin.

James, Marquis

1975 The Raven: A Biography of Sam Houston. Mockingbird Books. Atlanta.

Jimenez Moreno, Wigberto y Alfonso Garcia Ruis

1970 Historia de Mexico: Una Sentesis. Serie Historia VII, Instituto Nacional de Antropologia e Historia. Mexico. 
Jordan, Terry G.

1978 Texas Log Buildings: A Folk Architecture. The University of Texas Press. Austin.

Katz, Paul R.

19771975 Archaeological Investigations at Old Ursuline Academy, San Antonio, Texas. Archaeological Survey Report No. 34, Center for Archaeological Research, The University of Texas at San Antonio.

Kelley, Roger E. and Marsha C. Kelley

1979 Brick Bats for Archeologists: Values of Pressed Brick Brands. Historical Archeology 11: 84-89.

Kovel, Ralph M. and Terry H. Kovel

1953 Dictionary of Marks - Pottery and Porcelain. Crown Publishers, Inc. New York.

Lief, Alfred

n.d. A Close-up of Closures: History and Progress. Glass Container Manufacturers Institute. New York.

Lindeman, Carla G. and David W. Nystuen

1968 The Joseph R. Brown House: Final Report on Archaeological Excavations. Historical Archaeology Series No. l, Minnesota Historical Society. St. Paul.

Malone, James M., Georgeanna Greer and Helen Simons

1979 Kirbee Kiln: A Mid-19th Century Texas Stoneware Pottery. Office of the State Archeologist, Report 3l, Texas Historical Commission. Austin.

Manucy, Albert

1949 Artillery Through the Ages: A Short Illustrated History of Cannon, Emphasizing Types Used in American National Park Interpretive Series, History No. 3, U.S. Government Printing Office. Washington.

Meinig, D.W.

1975 Imperial Texas: An Interpretive Essay in Cultural Geography. The University of Texas Press. Austin.

Miller, Thomas Lloyd

1967 Bounty and Donation Land Grants of Texas 2835-2888. The University of Texas Press. Austin.

Montgomery Ward Co. 1969 Montgomery Ward \& Co. Catalogue and Buyers' Guide 
No. 57, Spring and Summer 2895. Dover Publications, Inc. New York.

Morrison, Hugh

1952 Early American Architecture from the First Colonial Settlements to the National Period. Oxford University Press. New York.

Munsey, Cecil

1970 The Illustrated Guide to Collecting Bottles. Hawthorne Books, Inc. New York.

Nelson, Lee H.

1968 Nail Chronology as an Aid to Dating Old Buildings. American Association for State and Local History Technical Leaflet 48. History News 24 (11).

Priess, Peter J.

1974 Wire Nails in North America. The Society for Historical Archaeology, Newsletter $7(1):$ 22-28.

Ray, Worth S.

1970 Austin Colony Pioneers. Pemberton Press. Austin.

Schuler, Stanley

1973 The IlZustrated Encyclopedia of Carpentry and Woodworking Tools, Terms and Materials. Pequot Press/Random House. Chester, Conn., New York.

South, Stanley

1977 Method and Theory in Historical Archeology. Academic Press. New York.

Switzer, Ronald R.

1974 The Bertrand Bottles: A Study of 19th Century Glass and Ceramic Containers. Publications in Archeology No. Z2, National Park Service, U.S. Department of the Interior. Washington.

Toulouse, Julian Harrison

1971 Bottle Makers and Their Marks. Thomas Nelson, Inc. New York.

Webb, Walter Prescott and H. Bailey Carroll (eds.)

1952 The Handbook of Texas, Vol. I. Texas State Historical Commission. Austin.

Westbury, William A.

1976 Archeological Investigations at Fort Richardson State Park, 1976. Report No. 37, Anthropology Laboratory, Texas A\&M University. College Station. 
White, Henry Packard and Burton D. Munhall

1963 Cartridge Headstamp Guide. H. P. White Laboratory. Bel Air, Maryland. 
APPENDIX 1

\section{ARTIFACT DESCRIPTIONS}

A large quantity of artifacts (a total of 57,728 ) was recovered during the excavations. These items range from ring-pull tabs from aluminum soft drink cans, cigarette filters, and other recent 20 th Century artifacts to mid-19th Century whiskey bottles and ceramics. The variety of artifacts ranges from architectural items to personal jewelry with virtually everything between represented. A number of organizational approaches were considered, all of which are in current use. A strictly functional approach comprising categories such as "personal adornment," "weapons," and "architecture" was rejected as being ambiguous for certain kinds of artifacts and subject to widely varying interpretations.

An alternative approach was to organize the artifacts strictly by categories of material of manufacture. This was seen both as too restrictive in one sense and as too inclusive in another. It was decided that a modified organization exhibiting certain characteristics of both approaches was the most appropriate for this report. Major categories are based on material of manufacture but within these large categories functional and/or descriptive categories are used. This allows some abiguity in that certain functional categories (buttons, for example) might be described under several material categories ( $i . e .$, iron, glass, bone). It also poses difficulties for comparisons with South's (1977) artifact patterns, but this data can be extracted if necessary.

In appropriate instances, artifacts are described in detail and dates or ranges of dates of manufacture and explanations of functions are provided. For many categories of artifacts, however, it is felt that merely listing them and providing provenience data is sufficient. These items are artifacts that are frequently reported in historic archeological site reports and whose age ranges and functions are well known.

A provenience table is provided in this appendix immediately following the artifact descriptions (Table 4). In order to facilitate artifact analysis and enhance the utility of the report for further research or reference, the test pits have been arranged in groups reflecting major feature associations on the site; these five groups include:

$$
\text { Group I - Test Pits } 1 \text { through } 4 \text { and } 36 \text { associated }
$$
with 20th Century activities around the 
front and sides of the present house position.

Group II - Test Pits 5 through 12, 14, 16 through 21, 23 through $27,30,32$ and 34 associated with late 19th and early 20th Century post mold configurations thought to represent additions to the structure.

Group III - Test Pits 22, 26, 28, 29, 31, 33, 35, 39, and 41 through 44 associated with the 19 th Century original house position.

Group IV - Test Pits 37,38 and 40 associated with the original kitchen location.

Group V - Test Pits 13, 15 and 45, a set of units south of the original kitchen.

The provenience table was organized in terms of these groups due to the large number of test pits excavated and the size of the artifact inventory. It should allow ready comparisons with the associated groupings of features.

\section{CERAMICS}

$\underline{\text { Pearlware }}$

Plain Body Sherds (1114 specimens): All ceramics in this category consist of undecorated sherds of plates, saucers, cups and other similar items. They lack indications of rims or bases but have characteristic white glaze and white paste.

Plain Rim Sherds (341 specimens): The sherds are from plates, shallow bowls, cups and chamber pots and are simple rounded rims.

Plain Base Sherds (122 specimens): The sherds include bases of a serving platter, plates and cups and a possible vase. They are simple low annular rings, many exhibiting a slightly blue accumulation of glaze at the annular ring.

Plain Handles (13 specimens): Four varieties of handles were encountered in the sample: a simple half tear drop, a rectangular shape, a tapered appliqued loop and a broad strap. 
Transfer Printed Blue (57 specimens): Two varieties of transfer printing were encountered, underglaze and overglaze. The overglaze transfer print specimens are all a light blue rambling rose design with large areas of open space. The underglaze specimens consist of a greater variety of motifs including a dot loop and bar motif, a cartouche and bar motif, a scallop, dot and lobed flower motif, a Chineselike geometric/naturalistic motif and a figural element showing a couple on the bank of a lake or river (Fig. $6 e, h$ ).

Transfer Printed Red ( 6 specimens): Three specimens are crimson with floral motifs while the remaining are magenta or purple with geometric/floral motifs.

Transfer Printed Green (13 specimens): All specimens are overglaze floral patterns.

Transfer Printed Brown (16 specimens): Of the 16 specimens, eight pertain to a single vessel (a bowl) having a marine, floral and geometric design with human figures (Fig. 6d). On the interior of the vessel is a linear floral motif. The remainder of the sherds are floral motifs except for an apothecary jar with the following inscription:

$$
\begin{gathered}
\text { ON } \\
\text {-DUST } \\
\text { Temper } \\
\text { GALI }
\end{gathered}
$$

Transfer Printed Brown/Hand Painted ( 7 specimens): All specimens are brown transfer printed floral designs with leaves and flowers hand colored (Fig. 6f).

Rim Banded (11 specimens): These specimens arte characterized by a thin brown band on the interior of plates.

Gilt Banded (23 specimens): All have a thin gold band at the interior lip of plates (two shallow and two deep).

Embossed Body (20 specimens): All specimens are embossed with floral and scroll motifs while one has vertical flutes.

Embossed Rim (14 specimens): Specimens exhibit floral or scroll motifs, scallops, flutes and one is embossed with a fan motif.

Black Band (4 specimens): All are sherds of a single cylindrical vessel having an everted rim with a black band. 
Figure 6. Artifacts.

a. Blue Spatterware Rim Sherd

b. Blue Stencilware Rim Sherd

c. Banded Slipware Body Sherd

d. Brown Transfer Print Body Sherd

e. Blue Transfer Print Rim Sherd

f. Brown Transfer Print with Green Hand Painting Rim Sherd

g. Porcelain Colander(?) Body Sherd

h. Blue Transfer Print Body Sherd

i. Decalcomania Rim Sherd

j. Lusterware Rim Sherd

k. Decalcomania Body Sherd

2. Porcelain Figurine Torso

m. Porcelain Figurine Foot

n. Porcelain Doll Ear

o. Porcelain Doll Arm

p. Smoking Pipe

q. Gold-plated Clasp

r. Gold-plated Pendant Inscribed "Mamma"

s. Ringset, Black Glass or Hematite

t. Ringset, Red Glass

u. Lead Seal 
Figure 6
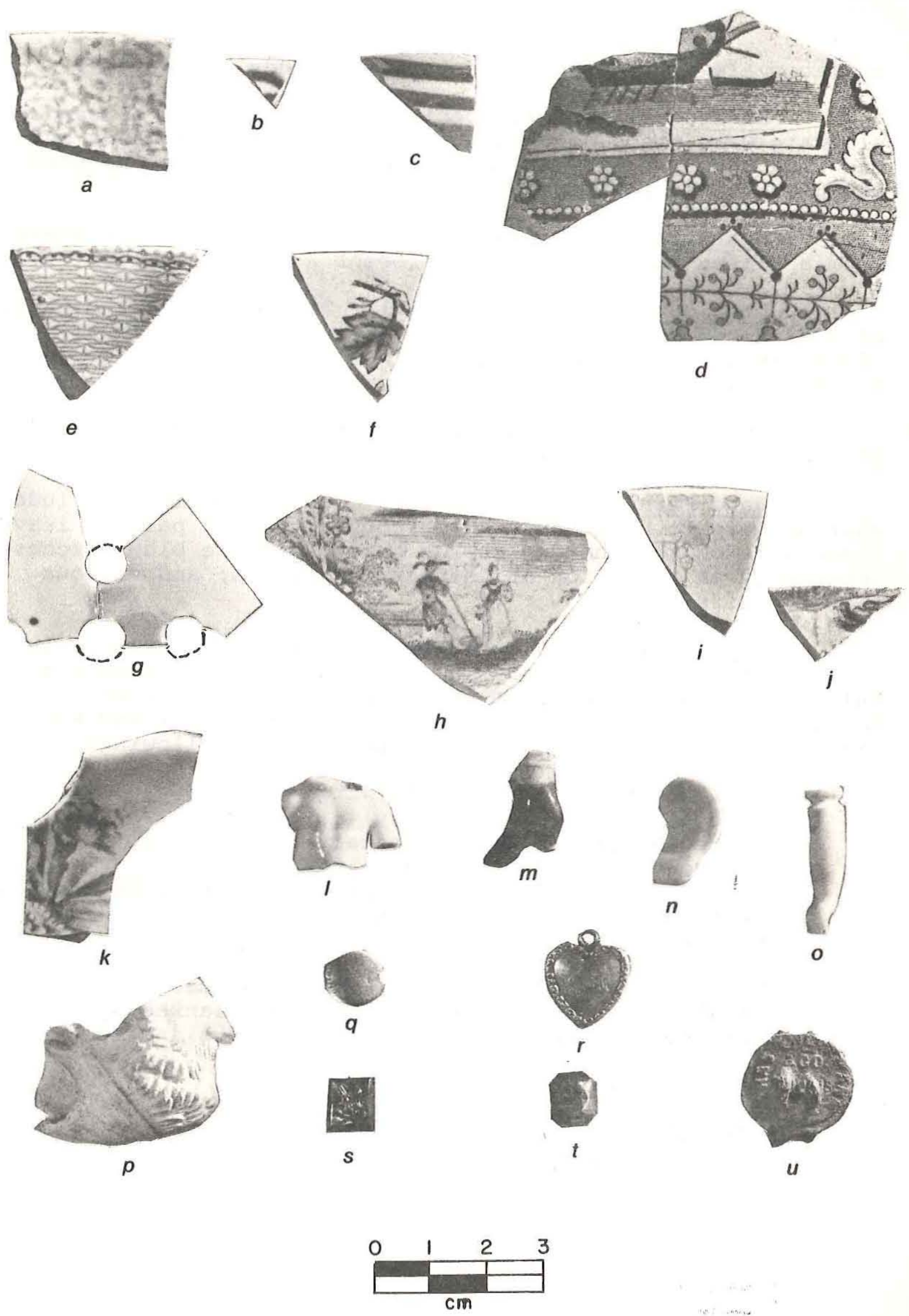
At intervals are two horizontal narrow bands on the body.

Banded Slipware ( 7 specimens): Two groups of banded slipware were noted, one with blue and blue-green bands and one with brown, yellow and orange bands on white. The blue group contained four sherds (Fig. 6c).

Spatterware (4 specimens): All sherds are rim sherds from a plate; they appear to represent a single vessel (Fig. 6a).

Decalcomania (12 specimens): These specimens consist of a pink and green geometric floral motif with vertical lines pendant arranged along the inside of the rim and various floral motifs on body sherds (Fig. 6i,k).

Applique (2 specimens): The two sherds have narrow blue appliques apparently of floral motifs.

Hand Painted (9 specimens): These specimens include what appears to be a gaudy Dutch copy with hand painted leaves observable on the sherds; sherds having diffuse blue patches apparently in imitation of Chinese porcelains; and various floral motifs.

Maker's Mark (60 specimens): Although a relatively large number of fragmentary maker's marks were encountered, only a small number of them could be identified (Kovel and Kovel 1953; Cushion 1959; Jackson 1977; and Carter and Ragsdale 1976). The identified specimens include the following:

E. \& C. Challinor (1862-91) England

Hope \& Carter (19th Century)

Alfred Meakin (1881--) Tunstal, England

Bridgewood and Clarke (1857-1864) England

Bridgewood and Son (19th Century) Longton, England

Wedgewood (19th Century) Tunstal, England

Haviland (1876) France

The unidentified fragments include primarily sections of an oval shield surmounted by a crown and flanked by a lion on the left and a unicorn on the right. Others include:

(1) LE CHIN

(2) shield

-ORCELAIN

- \& CO. 


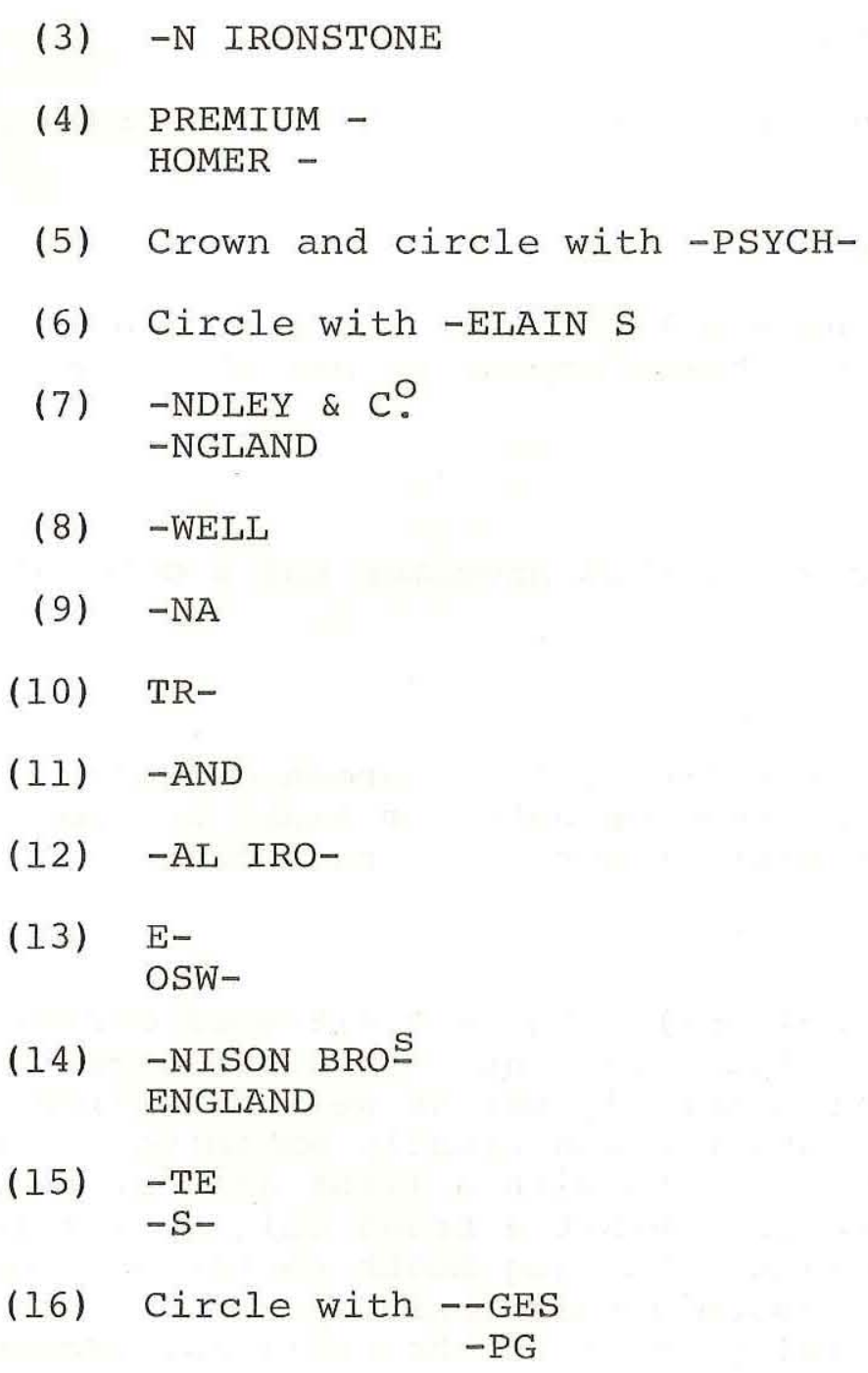

Stencilware (1 specimen): A single small rim sherd exhibiting a small fragment of blue stencil design (Fig. 6b). Creamware

Plain Body (20 specimens): The sherds have a creamcolored paste $\overline{\text { and }}$ clear glaze.

$\underline{\text { Rim (1 specimen) }}$

annular $\frac{\text { Base (2 specimens): Small segments of flat bases on }}{\text { rings. }}$

Banded Slip (1 specimen): A single cream sherd with horizontal blue bands. 
APPENDIX 1:

Ename1 Ware (24 specimens)

clear glaze.

Cream-colored paste with green, blue or yellow slip and

Blue Ware (11 specimens)

These sherds have a light blue porcelaineous paste with a clear glaze; the sherds appear to pertain to a single embossed vessel.

Brown Ware (1 specimen)

Like the blue ware, this specimen has a colored (brown) paste and a clear glaze.

Tiles ( 7 specimens)

These items are white or light green glazed one-inch (2.54 cm.) square tiles used on bathroom sinks or cabinets; one specimen is a red paste floor tile fragment.

Stoneware

Texas (272 specimens): The semivitreous ceramics of varicolored paste and glaze are generally denominated stoneware. The Texas stoneware is generally not as well vitrified as European or modern stonewares and usually exhibits a creamcolored to yellow-orange paste with a light grey or grey glaze. Virtually all rims sherds exhibit a broad collar or a rounded and/or flattened lip ring. Two jug mouth sherds are included in the sample. It is assumed that these specimens were made by Texas potters generally prior to the Civil War (Malone, Greer and Simons 1979: 46-47).

Flocculated (1 specimen): This specimen is a very small thin sherd with a cream paste and a flocculated brown glaze. The glaze is thick and tends to form clumps; ash or colemanite can cause flocculation (Fournier 1973: 86).

Pipe Fragments (17 specimens): A considerable variety of paste is present in the ceramic pipe fragments. Two pipe fragments are intact to a larger degree than the remainder. One is made of a white paste bisquite pressed into a mold to produce the face of a bearded man (Fig. 6p). It is an elbow pipe similar to many made in the period 1840-1860, some of which were political campaign gimmicks. The second specimen was molded into a plain elbow mold to produce a small 
flattened collar. The paste is dark brown and the glaze is somewhat mottled ranging from yellow-brown to medium chocolate brown to orange. The remainder of the sherds exhibit a collar about $3 \mathrm{~mm}$. below the lip. Paste ranges from dark brown to black to light grey. Glazes, when present, are clear to redbrown. All are similar to pipes made by the Pomplin Pipe Company of Virginia (Hamilton and Hamilton 1972: 2-47).

\section{European (35 specimens): All sherds are highly} vitrified stonewares in bottle form similar to Switzer's Class 1, Type 1 (and Subtypes a-f) and Class 1, Type 2. These are identified by Switzer (1974: 9-15) as being imported from England and the Netherlands.

Sewer Pipe (14 specimens): The specimens are fragments of red-brown ferruginous paste sewer pipe having a pebbly brown flocculated glaze.

Marbles (1 specimen): The specimen is a $22 \mathrm{~mm}$. diameter white paste, highly vitrified globe having a mottled light and dark brown glaze. Impact fractures are present at a number of points on the surface of the specimen.

Porcelain

Plain Body Sherds (291 specimens): Sherds of cups, saucers and plates.

Plain Rim Sherds (109 specimens)

Plain Base Sherds (50 specimens): The sherds all exhibit small, thin annular rings.

Plain Handles (13 specimens): These handles are all simple half tear drop shaped cup handles.

Embossed ( 9 specimens): The plain embossed sherds have floral motifs embossed near the rim and consist of plates, bowls and a cup. The cup sherds comprise a design of vertical flutes.

finial of a lid.

Embossed Finial (1 specimen): Floral motifs on the

Embossed Filagree Rim (1 specimen): Sherd of a fancy plate or serving dish with an embossed and perforated rim having small connections to the main body. 
Transfer Printed ( 6 specimens): The specimens are characterized by two types of transfer print, one apparently oriental and the other a floral motif with hand painting. The oriental-like sherds exhibit fine line drawing of dwarf pine trees and flowers. There are a small number of specimens with overglaze transfer print with multicolored floral motifs and a small number with green underglaze transfer print.

Transfer Printed/Painted (3 specimens): A red floral motif on an embossed base of a vessel similar to a cylinder or vase in form. The embossing is floral and the large flowers are filled with broad areas of light blue or purple.

Lusterware (17 specimens): All of these sherds exhibit a light pink color with dark pink wavy bands along the rims of shallow bowls or plates. The dark band generally is outlined with a gold gilt line (Fig. 6j).

Figurine (33 specimens): In this group are a variety of items which include the upper portion of a pearl-glazed torso and a glazed tubular fragment of unidentifiable form. The base of a figurine with a hand remaining as the only identifiable part is also included. The remainder of the sherds are bisque. Of these, one is tinted a light pink (a doll cheek) and one has a brown glaze only on a foot to indicate a shoe. The bisque fragments include portions of faces (forehead or cheek), an ear, portions of hollow limbs and two small solid arms and a calf and foot (Fig. $6 l, m, n, 0$ ).

Button (5 specimens): Simple discoidal buttons with beveled edges and a depressed center perforated with four holes. All of these buttons are dress size.

Miniatures ( 3 specimens): These specimens are fragments of toy cups, a small square-footed bowl and a round-footed bowl.

Colander ( 3 specimens): Fragments of a hemispherical or spherical vessel of thin pearl-glazed porcelain perforated with $7 \mathrm{~mm}$. diameter holes. The function could be a colander, or perhaps a pommander, although the holes are large for the latter function (Fig. $6 \mathrm{~g}$ ).

Spatterware (7 specimens): The sherds appear to be from a pitcher or large, wavy-rimmed bowl with embossed floral motifs near the rim. The spatter blue design extends from the lip to near the base of the embossing (ca. $23 \mathrm{~mm}$.$) .$ 
Electric Socket (16 specimens): This group consists of two items. One sherd of an early 20 th century porcelain insulator and a light or electrical socket restored from the remaining sherds. The socket consists of a cylinder open at one end and partially closed at the other. The partially closed end is characterized by a raised ring and perforations. There are four equidistant perforations for screws partially cut into the ring and having a $2.6 \mathrm{~mm}$. diameter. A notched central perforation $9.4 \mathrm{~mm}$. in diameter is present. Around the central perforation are the letters PAT. MAR. 5. 01. On the interior of the socket are depressed areas around each perforation. The diameter of the socket is $30 \mathrm{~mm}$. with a total height of $24 \mathrm{~mm}$. including the $1.3 \mathrm{~mm}$. thick ring.

Flower Pot (38 specimens)

These items are unglazed permeable paste stoneware truncated conical vessels; two types of rim finish are present, a rounded lip and a pronounced collar.

Brick (421 specimens)

A large number of both modern and old bricks and brick fragments was encountered in the excavations. Numerous fragments were found near the brick features and smaller fragments were noted in all areas of the site. This represents only a small sample. Virtually all measurable bricks were $5.8 \times 9.7$ $\mathrm{x} 20.3 \mathrm{~cm}$.

\section{GLASS}

Complete Bottles ( 5 specimens) (Fig. 7a-c,g,h)

Of the thousands of bottle sherds encountered during the excavations, only five complete bottles were found. Two are very small probable perfume bottles, two are ink bottles and one is a Fletcher's Castoria children's laxative bottle.

The first specimen is a small unbleached cylindrical bottle blown into a three-part mold with the lip and upper neck hand finished. The body is cylindrical with rounded shoulders. The neck is also cylindrical with the middle circumference slightly expanded. The rim comprises a simple flattened collar and no makers mark is present on the base.

$\begin{array}{ll}\text { Height (total): } & 41.7 \mathrm{~mm} . \\ \text { Height (body): } & 25.4 \mathrm{~mm} \text {. }\end{array}$


Figure 7. Artifacts

a. Fletcher's Castoria Bottle (Group III Test Pits).

b. Perfume Bottle (Group II Test Pits).

c. Perfume Bottle (Group II Test Pits).

d. Lea \& Perrin's Worchestershire Sauce Bottle (Group II Test Pits).

e. Dickey's Eye Water Bottle (Group II Test Pits).

f. Johnson \& Rather Corner Drugstore Bottle Fragment (Group II Test Pits).

g. Ink Bottle (Group III Test Pits).

h. Ink Bottle (Group IV Test Pits). 

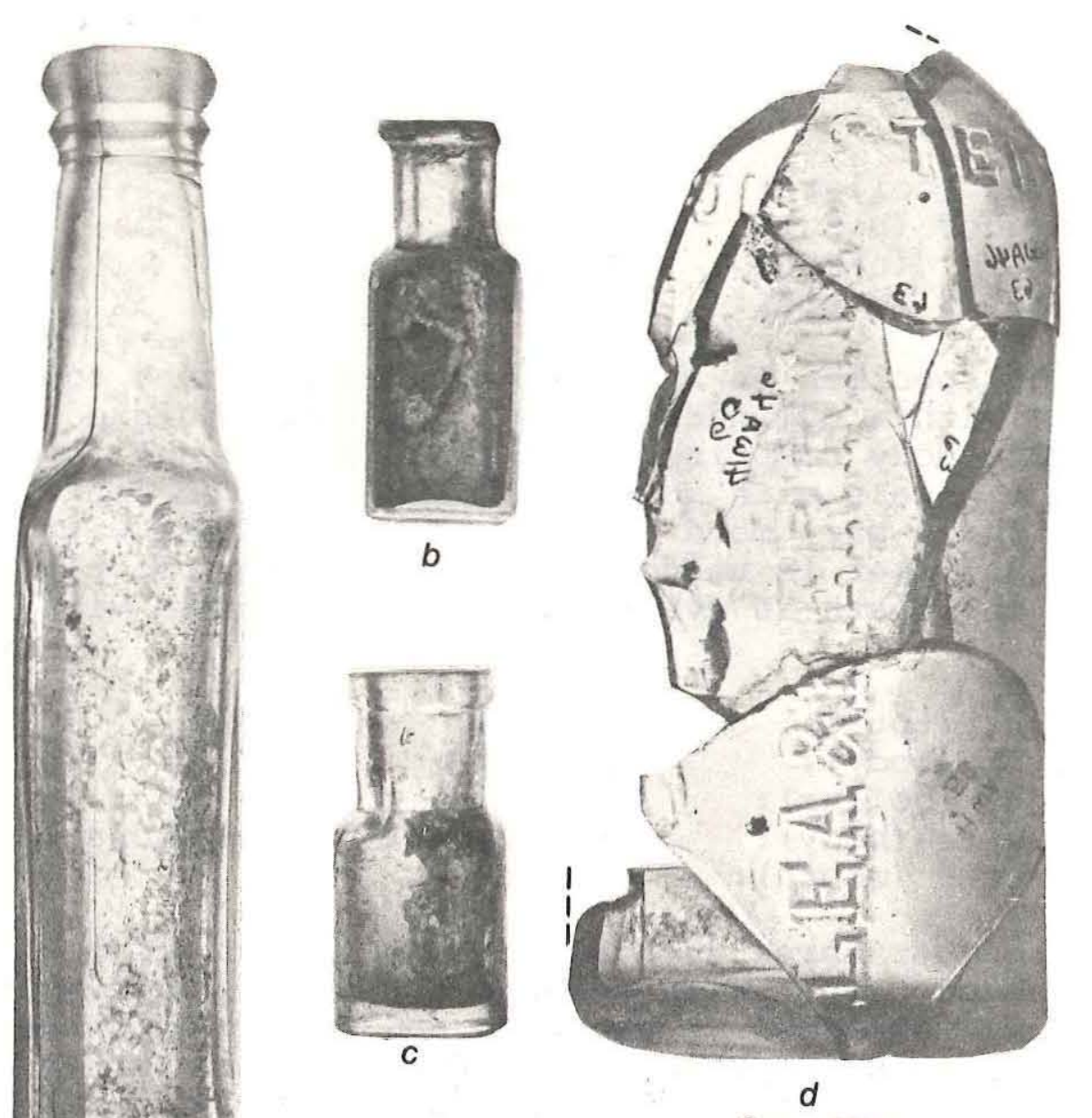

Figure 7
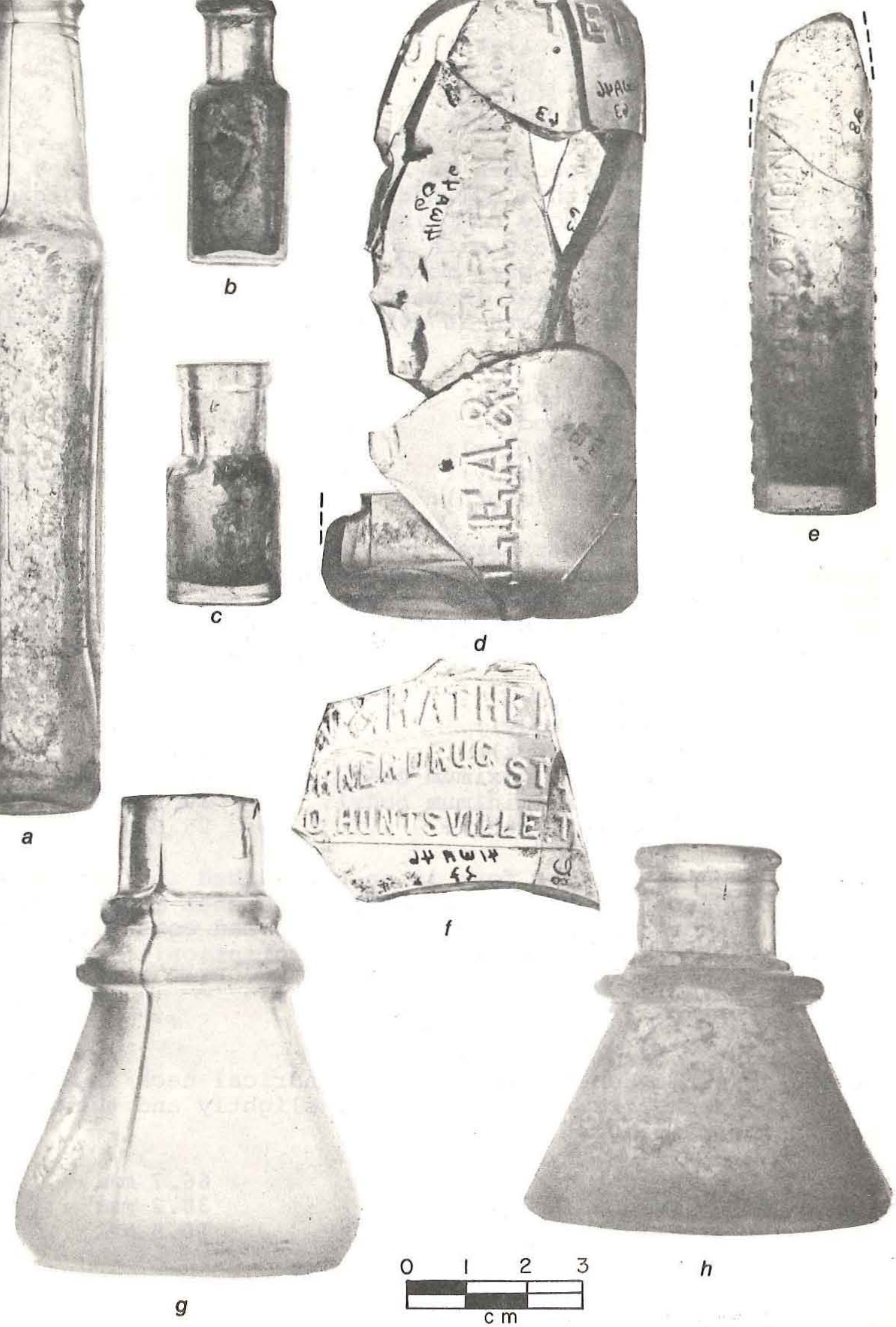

h 


$\begin{array}{lr}\text { Height (collar): } & 4.2 \mathrm{~mm} \\ \text { Diameter (body): } & 19.8 \mathrm{~mm} \text {. } \\ \text { Diameter (neck): } & 15.1 \mathrm{~mm} \text {. } \\ \text { Diameter (mouth): } & 16.5 \mathrm{~mm} \text {. }\end{array}$

The second specimen is a small selenite-bleached square base panel bottle with a cylindrical neck and hand-finished everted mouth. The body comprises four equal panels and four facets between the panels with rounded shoulders. The bottle was blown into a three-part mold and marked on the base with the letters GW; the maker is unknown. The neck is perfectly cylindrical, and the mouth is everted and hand finished with an irregular rim.

$\begin{array}{lr}\text { Height (total): } & 45.5 \mathrm{~mm} . \\ \text { Height (body): } & 31.2 \mathrm{~mm} . \\ \text { Height (collar): } & 3.1 \mathrm{~mm} . \\ \text { Diameter (body): } & 16.4 \mathrm{~mm} .(20 \mathrm{~mm} \text {. diagonal) } \\ \text { Diameter (mouth): } & 15.1 \mathrm{~mm} .\end{array}$

Specimen number three is a selenite-bleached ink bottle blown into a three-part mold with a cut-and-fire-polished mouth. The body is conical, expanded at the base and constricted near the top; no maker's mark is present. At the join between the cylindrical neck and body is an oval ring and expanded collar.

$\begin{array}{ll}\text { Height (total): } & 81.9 \mathrm{~mm} \\ \text { Height (body): } & 48.2 \mathrm{~mm} . \\ \text { Height (neck): } & 17.0 \mathrm{~mm} . \\ \text { Diameter (maximum body): } & 60.3 \mathrm{~mm} . \\ \text { Diameter (minimum body): } & 34.1 \mathrm{~mm} \\ \text { Diameter (neck): } & 25.6 \mathrm{~mm} .\end{array}$

Specimen number four is an unbleached ink bottle blown into a three-part mold with a machine-finished mouth. The body is conical and expanded at the base and constricted near the top; the base has the following inscription:

\section{CARTER'S}

39

At the join between the body and cylindrical neck is a double ring; the neck circumference expands slightly and the mouth is also a double ring.

Height (total):

Height (body) :

Height (neck) :
$66.7 \mathrm{~mm}$.

$38.2 \mathrm{~mm}$.

$10.0 \mathrm{~mm}$. 


$\begin{array}{ll}\text { Diameter (maximum body): } & 64.7 \mathrm{~mm} . \\ \text { Diameter (minimum body): } & 37.8 \mathrm{~mm} \text {. } \\ \text { Diameter (neck): } & 29.0 \mathrm{~mm}\end{array}$

The final complete bottle is an unbleached panel bottle blown into a four-part mold with molded mouth. The panels are recessed and two are broad while two side panels are characterized by embossed lettering. The base has the single embossed symbol "1." One panel has the script letters "Chas. H. Fletcher's" while the other has the word "CASTORIA." The neck is cylindrical but slightly constricted near the mouth. The mouth consists of a beaded ring and biconical collar.

$\begin{array}{lr}\text { Height (total): } & 145.0 \mathrm{~mm} \\ \text { Height (body): } & 101.0 \mathrm{~mm} \\ \text { Height (mouth): } & 11.3 \mathrm{~mm} \\ \text { Length (body): } & 48.4 \mathrm{~mm} \\ \text { Width (body): } & 24.8 \mathrm{~mm} \\ \text { Diameter (neck): } & 20.0 \mathrm{~mm} \\ \text { Diameter (minimum neck): } & 16.3 \mathrm{~mm} \\ \text { Diameter (mouth): } & 20.0 \mathrm{~mm}\end{array}$

Near Complete Bottles ( 5 specimens)

Four of the specimens are unbleached glass while the fifth specimen is amber or brown glass. They comprise sherds of bottles that could be partially reconstructed.

The first specimen is a small cylindrical bottle blown into a three-part mold (Fig. 7e). No inscription is found on the base but the following is embossed vertically down the side of the body:

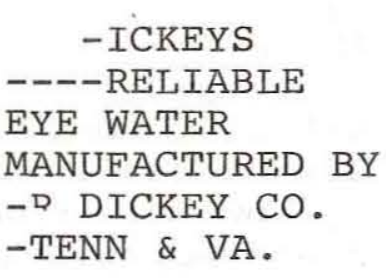

Diameter (body): Height (body) :

$$
\text { ca. } \begin{array}{r}
20.8 \mathrm{~mm} \text {. } \\
85.0 \mathrm{~mm} \text {. }
\end{array}
$$

Specimen two is a cylindrical bottle missing the base and neck. There are no embossed letters on the body. Shoulders are gently rounded. 
The third specimen is a cylindrical bottle blown into a three-part mold (Fig. 7d). The neck and mouth are missing. Embossed lettering appears on the base, vertically from bottom to top on the body and horizontally on the shoulder. Base lettering is:

$$
\text { J } \underset{S}{18 D}
$$

This bottle was manufactured by John Duncan and Sons, New York, between 1877 and 1920 under license to Lea and Perrins for imported sauce. The "18" indicates the mold number (Toulouse 1971: 277). Body embossing reads "LEA \& PERRINS," while shoulder lettering reads "WOR - ESTERSHI-E SAU--." The sauce was developed by Sir Marcus Sandys while in India as governor of Bengal. Returning to Worchester, he employed the chemists (druggists), John W. Lea and William Perrins, to make his secret recipe and later to sell it (Campbell 1964: 68-69).

Body Diameter: Body Height:
$54.5 \mathrm{~mm}$. ca. $118.0 \mathrm{~mm}$.

A fourth specimen is a panel bottle, unbleached, with three recessed panels and one nonrecessed nonembossed panel. No maker's mark is present on the base of the three-part mold bottle. One side panel has the embossed inscription reading from top to bottom "D' KENNEDY('S)." The front panel inscription reads:

\section{MEDICAL}

DISC--ERY

The remaining panel has the partial inscription "-- MASS."
Length (basal):
$82.0 \mathrm{~mm}$.
Width (basal):
$52.0 \mathrm{~mm}$.

The final partially complete bottle is an amber or brown bottle which was broken into many very small pieces. Many of these sherds, however, could be rejoined so that the entire bottle is reconstructable through projection and comparison. The design on the bottle and its shape is a fish with the mouth and head forming the mouth and upper portion of the bottle and the tail forming the base. Munsey (1970: 225) identifies this as a cod-liver oil bottle. No measurements are possible. 
Unbleached Bottle Glass (2435 specimens)

Among the large number of body, base, neck and mouth sherds of unbleached bottle glass are a small number of identifiable or potentially identifiable sherds or sherds of technological interest. These will be described, while the remainder will not.

Base Sherds:

$B \& C$

Possibly Bagley \& Co., Knottingley, Yorks, England (ca. 1899) (Toulouse 1971: 77).

LG Co.

Louisville, Kentucky Glass Works, Louisville, Kentucky. First established as the Kentucky Glass Works in 1849 by Taylor, Stranger, Ramsey and Co. then by George L. Douglass and James Taylor. The name was changed to Louisville Glass Works in 1855. The plant closed in 1873, was reopened under new ownership and the new name continued through 1886. The mark dates about 1880 (Ibid.: 323-324).

NBBG North Baltimore Bottle Glass Co., North 64 Baltimore, Ohio, 1885-1895; Albany, Ind., 1895-1903; Terre Haute, Ind., 1900-1930. Beer and beverage bottles ( $I b i d: 379-$ $380)$.

W.T.CO Whitall-Tatum \& Co., 1837-1938,

LB Unknown

$-\mathrm{N} \quad$ Unknown

P-- Unknown

--D.FEB.-- Unknown

In addition to these bases, there are several flat bases without marks (12 specimens). One base sherd is a conical kickup with traces of a blowpipe pontil scar and one base has a dramatic blowpipe pontil scar. 
Side or Panel Sherds: If there is more than one specimen with the same embossed letters, the number of specimens will follow the inscription in parentheses.

\begin{tabular}{|c|c|c|}
\hline$--G . I . H$. & $\begin{array}{r}--T^{\prime} S \\
\text { GOOD }\end{array}$ & -ATE- \\
\hline -HATTANO- & $-S-$ & -0 \\
\hline$-\mathrm{R}$ & -ARIO- & -COTT \\
\hline -AND- & -KY.- & -OTHING S- \\
\hline$S-$ & $-\mathrm{L}^{\mathrm{A}}$ & $\begin{array}{l}-S \\
-I T\end{array}$ \\
\hline DISCO- & $-\mathrm{RO}-$ & $-0-$ \\
\hline$-I M-$ & $-. D-$ & $-A-$ \\
\hline$-\mathrm{JC}-$ & BUF- & $\begin{array}{l}\text { FG- } \\
\mathrm{O}- \\
\mathrm{S}-\end{array}$ \\
\hline $\mathrm{CO}$ (2) & $\mathrm{CA}-$ & $-W 3-$ \\
\hline $\begin{array}{l}\text { JOHN R- } \\
\text { BRI- }\end{array}$ & $\mathrm{H}$ & $-M P-$ \\
\hline$-R E-$ & $-\mathrm{OF}-$ & $-\mathrm{HE}-$ \\
\hline -UI & PR- & 8 \\
\hline$-M-\quad(3)$ & $-\mathrm{NG} \quad \mathrm{C}-$ & -FL- (script) \\
\hline $\begin{array}{l}-E- \\
-O-\end{array}$ & $M-\quad(2)$ & $-\mathrm{RC}-$ \\
\hline$-\mathrm{EX}-$ & $-W^{\prime} S-$ & $-\mathrm{U}-$ \\
\hline$-W-\quad(2)$ & $-O-\quad(2)$ & $\mathrm{CU}-$ \\
\hline \multicolumn{3}{|c|}{$\begin{array}{l}\text { In addition to these obviously fragmentary and uniden- } \\
\text { elements are sherds of a cathedral bottle (2), one } \\
\text { hant fruit and one with concentric circles. }\end{array}$} \\
\hline
\end{tabular}

small number of classes as follows: 
I. Hand-finished neck and mouth with mouth folded to interior then expanded and fire polished (2 specimens) :

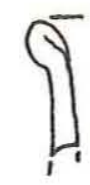

II. Mouth ring laid on or hand finished beyond mold marks. Ring flattened on top and exterior ( 6 specimens) :

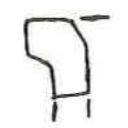

III. Broad laid-on mouth ring; hand-finished neck (4 specimens):

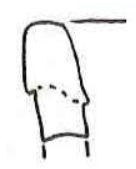

IV. Laid-on ring below mouth; ring is flat and broad (1 specimen):

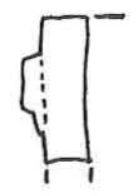

V. Laid-on ring at mouth; bead ring made by folding lip to exterior (2 specimens):<smiles>c1ccccc1</smiles>

VI. Laid-on collar; a conical collar; hand finished (1 specimen) :

$$
\bigcap_{1}^{-}
$$

VII. Bead and ring consisting of an external bead ring above a narrow bead ring (2 specimens):<smiles>C1CCCCC1</smiles> 
VIII. Biconical rings (1 specimen):

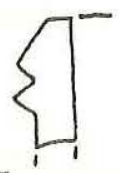

IX. Machine-molded bead near ring (3 specimens):

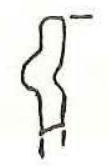

X. Crown-cap mouth consisting of a beveled ring and collar patented in 1891 (Lief n.d.: 17-20) (3 specimens):

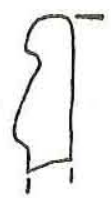

XI. Continuous threaded; molded with a cylindrical mouth and an embossed single thread $1 \frac{1}{2}$ turns with ring below. This was patented in 1919 (Ibid: 29).

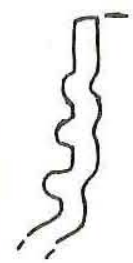

Manganese Bleached Bottle Glass (679 specimens)

Basal Sherds: Of 11 nearly complete bases, only four have embossed lettering:

(M)

HIRSCH BROS \& CO CATSUP

Lovi--
Maryland Glass Corp., Baltimore, Md., 1907 to present. Built for Emerson Drug Co. of Baltimore (Toulouse 1971: 339-340).

$\mathrm{O}$

One specimen is marked by a raised ring. 


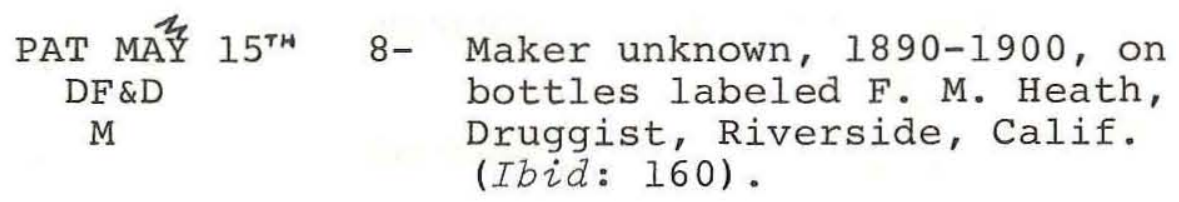

Side or Panel Sherds (5 specimens)

$$
\begin{aligned}
& -\frac{20}{-} \\
& -\mathrm{P}- \\
& - \text { CO } \\
& -. \mathrm{O}-
\end{aligned}
$$

HILA-

Necks and Rims (8 specimens): One specimen is identical to the Class III neck and mouth described above, and another is identical to the Class XI.

XII. A machine-finished rounded bead and short conical collar (1 specimen) :<smiles>C1CC2CCC(C1)C2</smiles>

XIII. Canning jar (3 specimens):

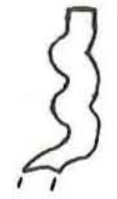

XIV. Everted interior ledge (2 specimens):

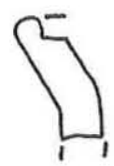

Selenite Bleached Bottle Glass (4616 specimens)

Basal Sherds (20 specimens):

I.G.-

Probably I.G.CO., Ihmsen Glass Co. of Pittsburg, Pa., 1855-1896 (Ibid: 261-264). 


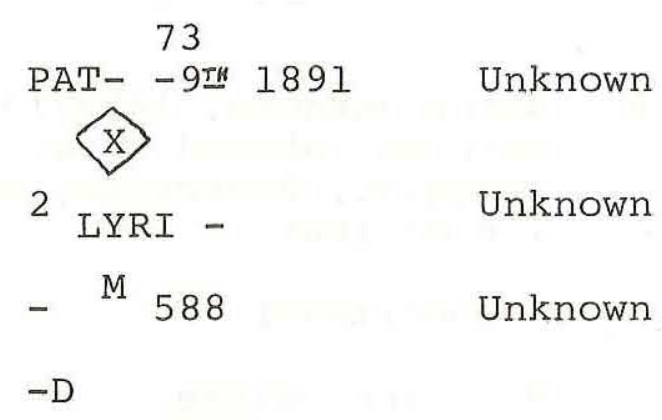

Side or Panel Sherds (64 specimens):

$-\mathrm{N} \&$ RATHER

-ORNER DRUG STO-

-O. HUNTSVILLE. T-

$3 \mathrm{iv}$

-ORK

$-\mathrm{T}-$

JF

$-\mathrm{E}-$

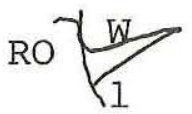

-OFL.O-

$-B E L-$

$-\mathrm{RB}-$

C-

$-\bar{\top}-$

$-\mathrm{SON}$

$-W-(2$ specimens $)$

$-G R-$
From the Johnson and Rather Corner Drugstore which presumably closed after 1895 (Fig. 7f)

Drug or medicine bottle

Probably New York

$-\mathrm{TF}-$

L.W.MOLOM-

97

$-E-$

$-\mathrm{G}-$

-EINZ-

$\mathrm{H}-$

-ESTS-

-NTS-

$-\mathrm{D}-$

AV-

$2 \mathrm{oz}$

-IL-

-U-

$3 \frac{7}{-}$

$-\&-$

$-\mathrm{O}-$

$-\mathrm{CO}$

$-S$

$-I-$

$-0-$ $-80-$

-CA-

-ADE- 


\begin{tabular}{|c|c|c|}
\hline -CKL- & $-\mathrm{NO}-$ & $\begin{array}{r}\mathrm{J}- \\
\text { Dru- } \\
\mathrm{U}-\end{array}$ \\
\hline $\begin{array}{c}\text {-UMERS } \\
\text {-RK }\end{array}$ & $\begin{array}{l}\text {-BROU- } \\
\text { - VORI- }\end{array}$ & $\begin{array}{c}-E \\
\text { PICKL- }\end{array}$ \\
\hline $\begin{array}{l}\text { DELIO- } \\
\text {-VORI- }\end{array}$ & 110 & $\begin{array}{l}-\mathrm{T}- \\
-\mathrm{W}-\end{array}$ \\
\hline -NUFA- & -YETH- & $\begin{array}{c}-\mathrm{O}- \\
- \text { uggist }\end{array}$ \\
\hline -lle. Tex- & -NIA E- & $\begin{array}{l}\text { AR- } \\
\text {-EXTR- }\end{array}$ \\
\hline -OT- & $-C \cdot \downarrow-$ & $-\mathrm{OF}-$ \\
\hline$-S \cdot M_{0}-$ & -ALI- & $-Z I-$ \\
\hline .U.S.A. & $-\mathrm{N}-$ & $-\mathrm{A}-$ \\
\hline$-M-$ & $\underline{1}$ & $-S$ \\
\hline$-V-$ & BOYD'S & \\
\hline
\end{tabular}

Necks and Rims (50 specimens):

I. 1 specimen

II. 28 specimens, including two very small 11 and 13 mm. diameter mouths and two specimens with neck. rings at the midpoint of the necks.

V. 3 specimens

VII. 1 specimen

IX. 5 specimens

X. 3 specimens

XI. 2 specimens

XV. I specimen; a simple turned everted mouth, firepolished and ground on the interior.

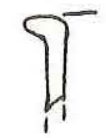


XVI. 4 specimens; simple cylindrical neck with the mouth cut and polished.

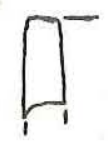

XVII. 1 specimen; molded collar and ring, fire polished.

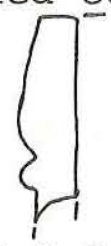

XVIII. I specimen; molded double ring and collar. The mouth consists of a ring, a biconical ring and a flat collar made in a separate three-part mold.

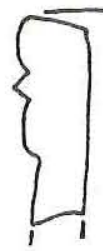

Brown Bottle Glass (1202 specimens)

Marked Bases:

10<smiles>[M]C1CCC1C(CO)CCO</smiles>

9

M7
Unknown

Unknown

Unknown

Unknown

In addition to the marked bases are fragments of two modern beer bottle bases, four cylindrical bottles and five square or panel bottles.

Side or Panel Sherds (12 specimens):

\begin{tabular}{|c|c|c|}
\hline -OWN- & $-\mathrm{N}-$ & $-\mathrm{PR}-$ \\
\hline$-\varepsilon-$ & $-\mathrm{R}-$ & -IR- \\
\hline -ALI $\quad W-$ & $-\mathrm{T}-$ & $-I E-$ \\
\hline$-\mathrm{NA}-$ & $-\mathrm{P}-$ & -TERS \\
\hline
\end{tabular}


$\underline{\text { Neck }}$ and Rim Sherds (8 specimens):

V. 1 specimen

VI. 2 specimens

XI. I specimen

XVII. 1 specimen

XIX. 3 specimens; molded everted lip. These specimens appear on snuff bottles.

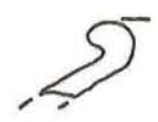

Green Bottle Glass (587 specimens)

Bases ( 6 specimens):

Kickup bases (4 specimens)

Flat bases (2 specimens)

$\underline{\text { Neck }}$ and Rim Sherds (4 specimens):

IV. 1 specimen

V. 1 specimen

XIX. 1 specimen

Xx. 1 specimen; laid on collar and ring.

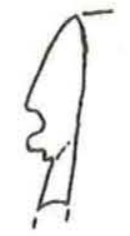

Miscellaneous Glass Buttons (30 specimens)

The numerous buttons come in a range of sizes, shapes, colors and techniques of attachment.

I. Colored glass; discoidal with depressed center; four holes ( 7 specimens). 


$\begin{array}{ccccc}\text { Diameter } & \text { Black } & \text { Brown } & \text { Blue } & \text { Green } \\ 10 \mathrm{~mm} . & 3 & 1 & & 1 \\ 11 \mathrm{~mm} . & 1 & & 1 & \end{array}$

II. Black irridescent (blue-green) glass; discoidal; two holes; concave face (1 specimen).

Diameter: $15 \mathrm{~mm}$.

III. Black glass; discoidal; flat to convex face; convex rear with nipple; embedded omega $\Omega$ copper wire loop in nipple; face is figured with geometric motifs ( 9 specimens) (Fig. $8 k-n, q)$.

$\begin{array}{lll}\text { Diameter: } & 12.0 \mathrm{~mm} . & 2 \text { specimens } \\ 13.0 \mathrm{~mm} . & 1 \text { specimen } \\ 14.0 \mathrm{~mm} . & 1 \text { specimen } \\ 15.5 \mathrm{~mm} . & 2 \text { specimens } \\ 16.0 \mathrm{~mm} . & 2 \text { specimens } \\ 17.0 \mathrm{~mm} . & 1 \text { specimen }\end{array}$

IV. Black glass; omega wire attachment; one oval with two Greek heads, male and female; one rectangular with geometric leaflike design; two faceted (4 specimens) (Fig. 8u).

$\begin{array}{llll}\text { Length } & 18.0 \mathrm{~mm} . & \text { Width } 14.0 \mathrm{~mm} . & \text { Oval } \\ \text { Length } & 19.0 \mathrm{~mm} . & \text { Width } 12.0 \mathrm{~mm} \text {. } & \text { Rectangular } \\ \text { Flats } & 12.0 \mathrm{~mm} . & \text { Points } 13.0 \mathrm{~mm} \text {. } & \text { Hexagon } \\ \text { Flats } & 11.0 \mathrm{~mm} . & \text { Points } 11.5 \mathrm{~mm} . & \begin{array}{c}\text { Hexagon star } \\ \text { motif }\end{array}\end{array}$

V. Black glass; flat face; raised rear with grooves and a horizontal perforation; geometric design (floral and horseshoelike) (2 specimens) (Fig. 8r).

Diameter: $13.0 \mathrm{~mm}$. $14.0 \mathrm{~mm}$.

VI. Black glass; globular grooves in rear and horizontal perforation; geometric design on face (1 specimen).

Diameter: $12.5 \mathrm{~mm}$.

VII. Black glass; hexagonal faceted face; concentric ridges in rear; omega attachment (l specimen).

Flats $17.0 \mathrm{~mm}$. Points $18.0 \mathrm{~mm}$. 
VIII. Clear glass, octagonal faceted diamond shape; perforated on two opposite sides (1 specimen) (Fig. 8p).

Flats $14.5 \mathrm{~mm}$. Points $15.0 \mathrm{~mm}$.

IX. Black glass; flat on one face; convex on the other; geometric design; fragmentary (1 specimen).

X. Black glass; elongated; biconical; rear grooved with perforated ridge (I specimen).
Length:
19.0 $\mathrm{mm}$.
Diameter:
$7.8 \mathrm{~mm}$.

XI. Black glass; hemispherical; omega wire loop attachment (1 specimen) (Fig. 80).

Diameter: $\quad 9.8 \mathrm{~mm}$.

XII. A cylindrical or nearly globular button with a flat inset face and a depressed rear for an omega attachment (1 specimen).
Diameter:
$9.3 \mathrm{~mm}$.
Height:
$7.5 \mathrm{~mm}$.

Blue Translucent Glass (66 specimens)

The blue translucent glass comprises essentially two groups, aqua glass and dark cobalt blue glass. One Class XVII bottle neck was encountered. A dark cobalt blue unmarked panel bottle and a side panel with the inscription "N-" were encountered. The remainder of the sherds are body sherds.

Blue Opaque (30 specimens)

Similar to milk glass, these sherds are fragments of small jars or lids and are generally too small for further identification.

Rose-Colored Glass (2 specimens) function.

A light pink to red-pink opaque glass of undetermined

Compound Rose/White (1 specimen)

This specimen is from a cylindrical vessel fragment; it is opaque white on the exterior and light pink opaque on the interior. 
Figure 8. Artifacts.

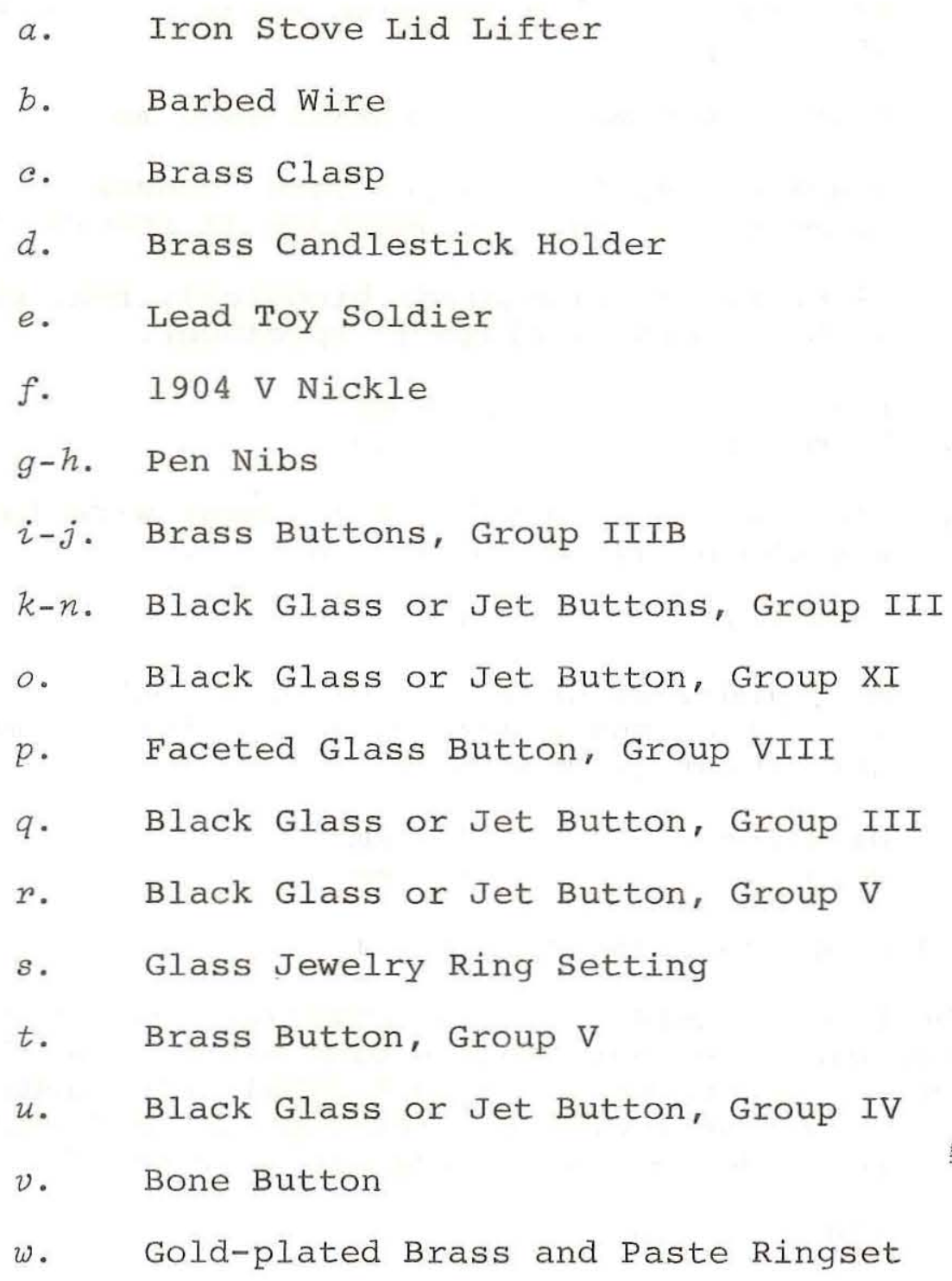


Figure 8
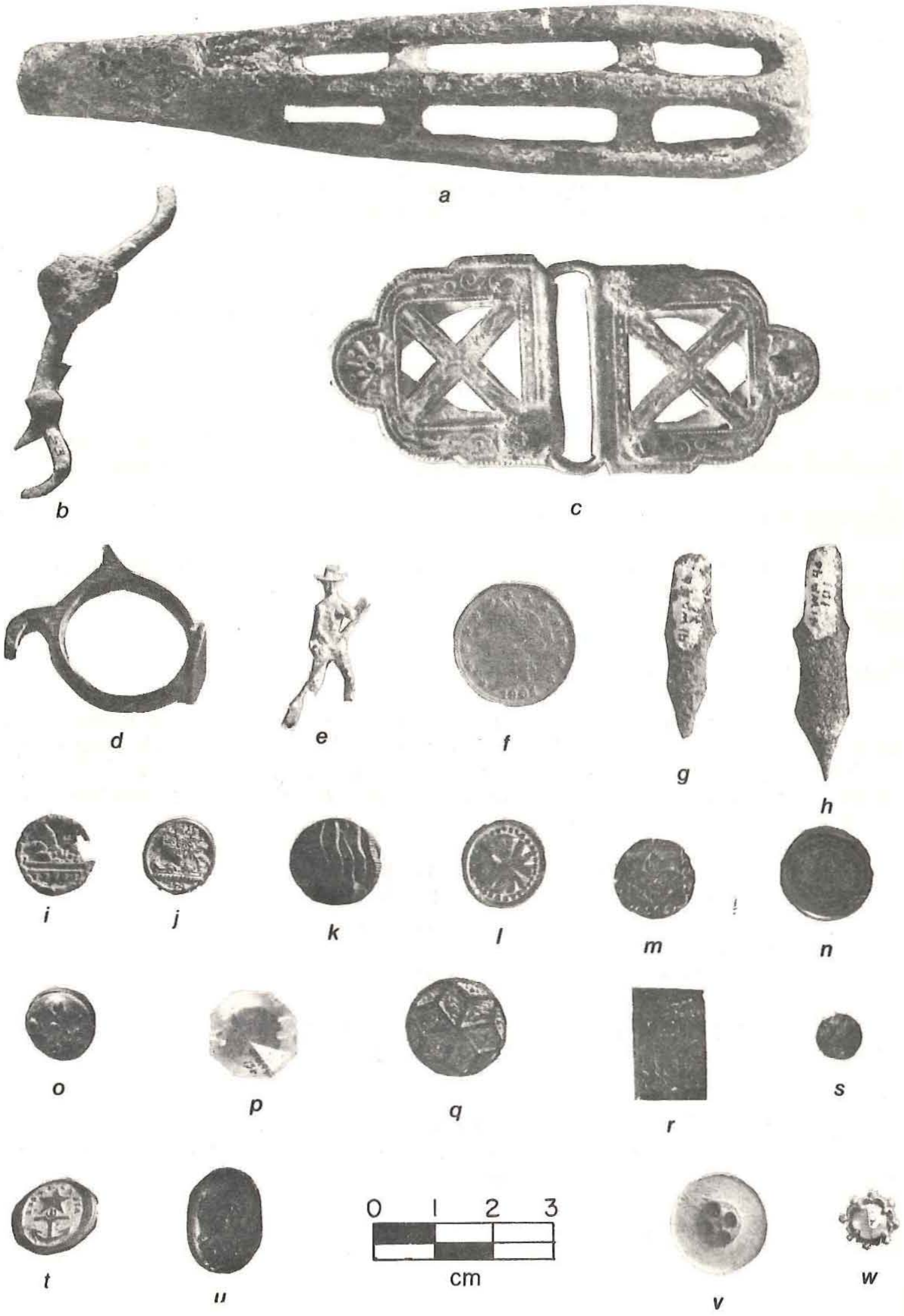
Yellow Glass (1 specimen)

Bottle body sherd from a small vessel.

Amethyst (1 specimen)

A dark red-purple glass in the form of a thin, flat oval beveled and faceted on the edge; function is unknown.

Salt Shaker (2 specimens)

Embossed rectangular checks commonly seen in restaurant salt and pepper shakers.

Corrugated Panels (3 specimens)

These are very small rectangular panels with vertical

beaded corrugations on one face; function is unknown.

Drawer Pull (1 specimen)

A clear glass drawer pull fragment perforated for a screw. It is round with basal torus below a concave scotia. The upper finial is broken.

Lamp Reservoir (29 specimens)

One specimen is partially restored from a number of sherds. The base is flat on an annular ring which supports a torus and narrow ring. This ring is surmounted by a faceted body having 12 vertical facets. Above this is a depressed ring, then a notched ring.
Total Height:
Maximum Diameter:
Internal Diameter:
Minimum External
Diameter:
$41.5 \mathrm{~mm}$.
$81.0 \mathrm{~mm}$.
$51.0 \mathrm{~mm}$.
$59.0 \mathrm{~mm}$.

A second specimen is a concave-sided flaring bowl

supported on a series of three ever-expanding tori and eightfaceted concave column capital and a hollow column.

The final specimen is an expanding cone circumscribed by an embossed ring. Too little of the artifact is present for a more detailed description.

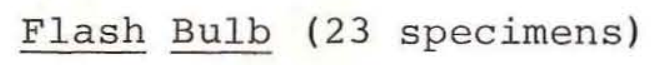


Etched Glass (1 specimen)

This specimen is characterized by a series of parallel textured and nontextured bands. It's identification as etched is highly questionable.

\section{Milk Glass (220 specimens)}

\section{Buttons (47 specimens):}

I. White milk glass; discoidal with depressed center; four holes (33 specimens).

$\begin{array}{llr}\text { Diameter: } & 8.0 \mathrm{~mm} . & 1 \text { specimen } \\ 8.5 \mathrm{~mm} . & 2 \text { specimens } \\ 9.5 \mathrm{~mm} . & 2 \text { specimens } \\ 10.0 \mathrm{~mm} . & 4 \text { specimens } \\ 10.5 \mathrm{~mm} . & 4 \text { specimens } \\ 11.0 \mathrm{~mm} . & 10 \text { specimens } \\ 13.0 \mathrm{~mm} . & 2 \text { specimens } \\ 14.0 \mathrm{~mm} . & 3 \text { specimens } \\ 14.5 \mathrm{~mm} . & 1 \text { specimen } \\ 16.0 \mathrm{~mm} . & 1 \text { specimen } \\ 17.5 \mathrm{~mm} . & 1 \text { specimen } \\ \text { Unmeasurable } & 2 \text { specimens }\end{array}$

II. White milk glass; discoidal with depressed center; four holes; printed with clusters of one central dot surrounded by 7 smaller dots (I specimen).

Diameter: $\quad 11 \mathrm{~mm}$.

III. White milk glass; discoidal with depressed center; four holes; fluted between center depression and edge (5 specimens).

Diameter:

$$
\begin{aligned}
& 7.0 \mathrm{~mm} . \\
& 10.0 \mathrm{~mm} . \\
& 10.5 \mathrm{~mm} . \\
& 14.0 \mathrm{~mm} . \\
& 15.0 \mathrm{~mm} .
\end{aligned}
$$$$
1 \text { specimen }
$$

2 specimens

1 specimen

1 specimen

1 specimen

IV. White milk glass; discoidal; two holes; slightly depressed around holes (3 specimens).
Diameter:
$8.5 \mathrm{~mm}$.
1 specimen
$9.5 \mathrm{~mm}$.
1 specimen
$10.0 \mathrm{~mm}$.
1 specimen 
V. White milk glass; discoidal; two holes; slightly depressed around holes; printed with red dots (1 specimen).

Diameter: $\quad 11 \mathrm{~mm}$.

VI. White milk glass; discoidal; two holes; concentric rings (2 specimens).

Diameter: $\quad 13.0 \mathrm{~mm}$. 1 specimen

$$
13.5 \mathrm{~mm} \text {. } 1 \text { specimen }
$$

VII. White milk glass; hemisphere with depression in rear (1 specimen).

Diameter: $\quad 11.0 \mathrm{~mm}$.

VIII. White milk glass; disc nipple on one face; depression opposite (1 specimen).

Diameter: $\quad 10.0 \mathrm{~mm}$.

Lid Liners (51 specimens): All are liners for canning jars similar to Boyd's jar liners.

Bottle (2 specimens): These appear to be small cosmetic jar fragments with flat bases and annular rings.

Bowl Rim ( 3 specimens): One is possibly a bowl or scalloped lid with the embossed legend "30.8," and the remainder are simple rims.

Lid (4 specimens): One is a flat lid with vertical raised flange around the circumference; embossed "HEBRA-." The remaining three are undecorated flat or dome-shaped specimens.

Body Sherds (113 specimens): These specimens are small fragments of cosmetic cream jars.

Lamp Chimney (6966 specimens)

Obviously, a very large number of lamp chimney sherds were found. A fraction of these sherds might be thin bottle glass or fragments of light bulb globes, but it is obvious that the vast majority of specimens are indeed chimneys of kerosene lamps. The lamps were developed principally after the Civil War and were used virtually universally until replaced 
by electric lights in the early 20th Century (in Texas rural areas and small cities).

Notable features of the collection were a number of rims. There was a small number of plain rounded rims and a vast majority of scalloped rims and one rim with a collar impressed with three interlocking rows of diamond-shaped reverse pyramids. The range on width of scallop elements is from $4 \mathrm{~mm}$. to $24 \mathrm{~mm}$. with virtually every size in between. For almost any segment of rim, the scallops are uniform, ranging from shallow ( $3 \mathrm{~mm}$ ) to deep (12 mm.). One scalloped specimen has shallow ribs depending from the center of each scallop. Minimum upper neck diameters appear to range from 38-42-44 mm.

A small number of apparent base sherds was noted. These were simple cut-and-ground rims.

Windowpane (8672 specimens)

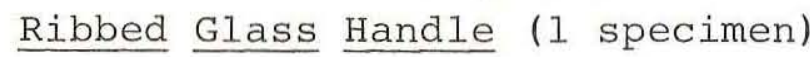

A glass cup handle with narrow vertical ribs on the exterior. The fragment is too small to determine the complete handle form.

Safety Glass (1 specimen)

A piece of heavy sheet glass with imbedded wire mesh.

Light Bulb (224 specimens)

These very thin curved sherds are thought to be fragments of early light bulbs.

Mirror Sherds (12 specimens)

Only sherds with a recognizable edge bevel or those retaining a small bit of the backing were included in this group. It may be assumed that many mirror sherds were included in the windowpane category.

Eye Glass (I sherd)

A small fragment of oval glass beveled on the edges. The glass is slightly thickened toward the center. 


\section{Drinking Glass (226 sherds)}

The sherds include a number of rims and bases of cylindrical drinking glasses. Several provide enough evidence for description.

I. A cylindrical glass with a concave base; no decoration (2 specimens).

$$
\text { Basal Diameter: } 65.0 \mathrm{~mm} \text {. }
$$

II. Knurled band around base; concave bottom (1 specimen).

III. Pressed design in concave base, sides, nine flat facets on body. Pressed design is radiating $\mathrm{V}$ grooves (1 specimen).

IV. Wide basal ring, concave base with embossed design, body with swirls. Embossed design is a circular flat area with embossed lines radiating from the circle into a gentle S-curve (l specimen).

V. Several sherds of both the bowl and base of a stemmed goblet. The shape is simple without decorative elaboration. The bowl is cylindrical with a hemispherical base sitting on a modified scotia which merges into a simple stem. The stem flares into a broad flat base.

VI. These glasses are known only from body sherds. There is a pressed design consisting of narrow, broad and narrow bands of narrow debossed vertical lines appearing near the rim. Near the base are a series of debossed V-grooves arranged in a scalloplike vertical fashion extending to the base. The bottom is concave.

Pressed Glass (66 specimens)

The small number of pressed glass sherds are divided into a relatively large number of categories based on design elements.

I. Naturalistic Motifs: One specimen (2 sherds) is a large flat panel (probably bottle) of brown or amber glass exhibiting a twig with leaves and pendant oval fruit. Another specimens has a 
five-pointed star. Two specimens have debossed horseshoes. One specimen has a crown surmounted by a five-pointed star. Two twigs with leaves are present on three specimens. Another specimen is the side of a serving dish having a branch with ball-tipped twigs on a modified herringbone background.

II. Flutes and Corrugations: These sherds are from a hemispherical bowl with a plain collar. Below the collar is a series of convex flutes converging toward the bottom. Each flute is interrupted at alternate intervals by a pattern of ridge-shaped corrugations.

III. Horizontal Rings: These items are cylindrical vessels with pressed convex horizontal rings decorating the body.

IV. Diamond Pattern: A Eairly wide variety of designs is represented by this group but all have fourpoint pyramidal diamond shapes as the common motif. Two specimens have debossed diamonds. Three specimens have rims, one a scallop with debossed V-grooves in a fan pattern and two with a denticulate pattern.

V. Pendant Leaves: The sherds form two sections of a dome-shaped lid with the design on the interior. The design consists of alternating pendant lobes, one with a central vertical ridge cut into a series of diamonds and the other pendant filled with a double row of diagonally bisected squares.

VI. Embossed Rings: The small interlocking rings form the entire base of a cylindrical vessel.

VII. Faceted Panels: The broad flats are square to rectangular. One specimen has indentations at the upper ends between two facets.

VIII. Debossed Ovals: One specimen has a pattern of vertically oriented debossed ovals arranged in a band near the base of a shallow bowl; another comprises a series of rings surrounding horizontally oriented ovals near the rim of a bowl.

IX. Embossed Leaf: The pattern consists of V-shaped grooves pressed into the glass to form ridged 
rectangles and leaf-shaped rectangles.

X. Hexagonal Pattern: Pressed V-shaped grooves form a series of six-pointed stars and hexagons. Each hexagon is flat on the top; one specimen has radiating grooves on the tops of the hexagon.

XI. Inverted V-ridges: Specimens appear to be shallow bowls with vertical ridges.

XII. Polygon Pattern: V-grooves produce versions of four-sided figures with varying proportions.

XIII. Swirls: The design consists of parallel grooves in a band. The grooves are oriented diagonally and imitate wood grain; they are located at the vessel rim.

XIV. Balls and Ridges: The design consists of diagonal lines of hemispheres and inverted notched V-ridges.

XV. Drapelike V-grooves: One specimen has a scalloped rim with pendant drapelike grooves and ridges. The remainder of the specimens exhibit curving parallel grooves and ridges.

XVI. Vertical Ridges: The pattern is a series of vertical rounded ridges of varying length forming a fanlike motif but with all the ridges parallel.

XVII. Debossed V- and U-grooves: The specimen is a scalloped rim sherd with horizontal, slightly curved, alternating narrow V-grooves and broad U-grooves.

XVIII. Embossed U-ridges: Thick curved U-shaped ridges; the design is too small to distinguish.

Beads (14 specimens)

I. Black glass globular faceted beads (6 specimens).

II. Black glass tubular faceted beads (1 specimen).
Length:
$5.4 \mathrm{~mm}$.
Diameter:
$6.6 \mathrm{~mm}$. 
III. Black glass tubular bead ( 1 specimen).
Length:
Diameter:
$23.0 \mathrm{~mm}$.
$4.0 \mathrm{~mm}$.

IV. Black glass globular bead (1 specimen).

Diameter: $\quad 9.0 \mathrm{~mm}$.

V. Blue glass tubular bead (I specimen); faceted with light blue core and dark blue exterior.
Length:
$5.4 \mathrm{~mm}$.
Diameter:
$5.6 \mathrm{~mm}$.

VI. Light blue globular glass bead (2 specimens).

Diameter: $\quad 7.0 \mathrm{~mm}, 7.6 \mathrm{~mm}$.

VII. Green globular glass bead (1 specimen).

Diameter: $\quad 9.3 \mathrm{~mm}$.

VIII. Clear lozenge (1 specimen). This is a clear glass object with two flat faces and parallel sides; one end is curved while the other is broken. The broken end thins toward the break. Two perforations are present on the object.
Width:
$11.3 \mathrm{~mm}$.
Thickness:
$3.2 \mathrm{~mm}$.

Marbles (9 specimens)

The marbles are of varying color and size with three blue, one white, two clear with yellow swirls, one clear with red, blue and white swirls and a clear fragment. Five of the specimens show heavy impact fractures on all areas. One blue marble is quite small and irregular. Two were too fragmentary for measurement.

$\begin{array}{rr}\text { Diameter: } & 9.0 \mathrm{~mm} . \\ & 14.0 \mathrm{~mm} . \\ 15.0 \mathrm{~mm} . & 16.5 \mathrm{~mm} . \\ 17.0 \mathrm{~mm} . \\ 18.0 \mathrm{~mm} . \\ 25.0 \mathrm{~mm} .\end{array}$


Jewelry (4 specimens)

Two items appear to be rectangular ring sets. The first item is a bright red glass faceted rectangle with beveled corners (Fig. 6t).

$\begin{array}{lr}\text { Length: } & 10.0 \mathrm{~mm} \\ \text { Width: } & 8.3 \mathrm{~mm} \text {. } \\ \text { Thickness: } & 2.5 \mathrm{~mm} .\end{array}$

The second specimen is a shiny black material, perhaps glass or hematite. It is rectangular with beveled edges and a flat back. On the face is the debossed carving of a Greek head with crossed spears below (Fig. 6s).

$\begin{array}{lr}\text { Length: } & 10.0 \mathrm{~mm} \text {. } \\ \text { Width: } & 8.0 \mathrm{~mm} \text {. } \\ \text { Thickness: } & 2.6 \mathrm{~mm} \text {. }\end{array}$

Another specimen is a faceted disc (Fig. 8s).

Diameter: $\quad 8.2 \mathrm{~mm}$.

The final specimen is a small glass diamond shape set into a pressed thin gold plated sheet.

Insulator ( 7 specimens)

These are very small aqua-colored fragments of late 19th or early 20th Century glass pole insulators.

Thermometer (1 specimen)

The specimen is a small segment of a fever thermometer with a subtriangular cross section. One face is inscribed "90 246 ;" another with a scale and the third with an imbedded white strip and the inscription "25424 LEGION."

Melted Glass (501 specimens)

These sherds represent a range of variation from glass totally melted and formed into drops to sheet glass warped out of shape.

Bottle Stopper (3 specimens)

One stopper is an unbleached stopper comprising a flat disc inscribed "LEA \& PERRINS" on a vertical post. 


$\begin{array}{lr}\text { Diameter of Disc: } & 25.0 \mathrm{~mm} . \\ \text { Diameter of Post: } & 11.0 \mathrm{~mm} . \\ \text { Thickness of Disc: } & 6.5 \mathrm{~mm} \text {. } \\ \text { Total Height: } & 32.8 \mathrm{~mm} \text {. }\end{array}$

A second stopper has a vertical oval handle with a serrated edge.

$\begin{array}{lr}\text { Length of Handle: } & 24.0 \mathrm{~mm} \text {. } \\ \text { Length of Post: } & 19.0 \mathrm{~mm} \text {. } \\ \text { Height of Handle: } & 20.0 \mathrm{~mm} \text {. } \\ \text { Thickness of Handle: } & 5.6 \mathrm{~mm} \text {. } \\ \text { Diameter of Post (Maximum) : } 12.5 \mathrm{~mm} \text {. } \\ \text { Total Height: } & 42.2 \mathrm{~mm} \text {. }\end{array}$

The remaining stopper has a flat D-shaped handle.

$\begin{array}{lr}\text { Length of Handle: } & 18.0 \mathrm{~mm} . \\ \text { Length of Post: } & 20.0 \mathrm{~mm} \text {. } \\ \text { Height of Handle: } & 12.0 \mathrm{~mm} \text {. } \\ \text { Thickness of Handle: } & 5.0 \mathrm{~mm} \text {. } \\ \text { Diameter of Post (Maximum) }: & 11.3 \mathrm{~mm} \text {. } \\ \text { Total Height: } & 35.0 \mathrm{~mm} .\end{array}$

IRON

Cut Nails (2565 specimens)

Cut nails were very common from the end of the first quarter of the 19th Century through the 1870s (Nelson 1968). The technology of their manufacture is well described in historical archeological literature, and they are still being made for special purposes. A wide variety of sizes was found in the excavations, ranging from large heavy framing nails to small shingle nails and including flooring nails as well as nails normally used on wood siding. Since no surface could be established and since there were so many disturbances, including plowing, no attempt at a nail analysis was made.

Wire Nails (1282 specimens)

Although wire nail technology was present in Europe in the late 18th Century, the technology did not develop in America until the late 19th Century. They became very inexpensive in the late 1870s and by the early 1880s generally and almost universally supplanted cut nails (Priess 1974). 
Unidentified Nails (9968 specimens)

A large number of the nails and nail fragments were too eroded or covered with oxidation and sandy loam cement to identify. It should be noted that a small number of both cut and wire nails were unaffected by weathering. It is to be assumed that japanning or galvanization was responsible for this phenomenon and that these particular nails had not been used. Still others were in extremely bad condition, perhaps from exposure to fire. No analysis of this group was attempted.

\section{Duplex Nails ( 1 specimen)}

Duplex nails are wire nails with a double head used in temporary framing and scaffolding (Burea of Navy Personnel 1972: 249).

Fence Nails ( 7 specimens)

Fence nails are long wire nails (ca. 25-30 cm.) having the distal or pointed end threaded about one-quarter to onehalf the length of the shank of the nail. They were driven through a large post, such as a corner post, and a female receptor attached to the wire was attached to tighten the wire.

\section{Masonry Nail (2 specimens)}

Shanks of these wire nails are notched or ribbed for driving into mortar or concrete.

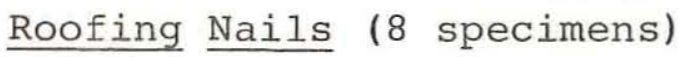

These nails are relatively short with broad heads used in attaching roofing felt, tar paper or roofing compound to wood sheathing. These are often used in combination with roofing caps (thin iron discs) to hold the roofing compound. One of the specimens retains the roofing cap fixed to the nail by oxidation residues.

\section{Upholstery Tacks (68 specimens)}

These items are short (ca. $5 \mathrm{~mm}$.$) cut and headed nails$ commonly utilized to tack upholstery on furniture.

Thumb Tacks (10 specimens) shaped head.

A small (ca. $5 \mathrm{~mm}$.$) wire attached to a very broad dome-$ 
Wood Screw (12 specimens)

Two classes of wood screws -- those with flat heads and those with round heads, all with simple slots. The flathead screws were dominant.

Sheet Metal Screw (3 specimens)

These screws are round-headed, simple, slotted screws with a flat tip designed for use on thin sheet iron.

Bolt ( 7 specimens)

Because of corrosion compounds adhering to the specimens, it is impossible to identify the bolt type.

Carriage Bolt and Nut (2 specimens)

These bolts have a round head, square or cylindrical shank and are threaded near the end of the shank.

Eye Bolt (1 specimen)

A heavy gauge wire or shaft looped on one end to form an eye and threaded on the opposite end.

Roofing Cap (10 specimens)

These items are small, flat sheet iron discs used to hold roofing (tar) paper to a wood base. Nails driven through the disc hold the paper while the disc distributes the area holding it to prevent tearing.

Fence Staple (34 specimens)

The specimens are U-shaped pointed heavy gauge wire used to fasten wire to wood posts.

Corrugated Fastener (2 specimens)

These items are commonly used to splice joints on small timber and boards. They are made of 18-20 gauge corrugated sheet metal with one end beveled and sharpened (Bureau of Navy Personnel 1972: 256).

Washer (2 specimens)

A simple, flat perforated disc. 
Door Latch (1 specimen)

A small iron screen latch hook.

Window Latch (2 specimens)

cabinet.

A flat galvanized latch hook for a window, shutter or

Safety $\underline{\text { Pin }}$ ( 3 specimens)

Fragmentary with sections of the loop spring.

Hat Pin (1 specimen)

A long, straight, pointed wire presumed to be a hat pin. Clothespin Spring (2 specimens)

These can be found presently on wooden clothespins.

Wire (112 specimens)

unknown.

Various gauges of single strand iron wire; functions

Barbed Wire (3 specimens) (Fig. 8b)

The one identifiable specimen appears to be a Stover's single wrap barb, single strand wire patented May 1, 1877 by Daniel C. Stover of Freeport, Illinois (Clifton 1970: 28). The remainder are unidentifiable because of oxidation residues adhering to the specimens.

Coil Spring (4 specimens)

Segments of tightly coiled wire spring similar to that used on screen doors.

Clasp (2 specimens)

One specimen (61 x $54 \mathrm{~mm}$.) consists of T-shaped sheet iron perforated near the end of each arm. A cut nail remains on one upper arm. The ends are rounded. The second specimen is also T-shaped but with squared upper arms (40 x $31 \mathrm{~mm}$.) and two perforations in the lower arm. 


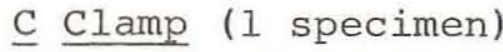

The specimen is the lower half of the clamp; that part having the threaded bolt. This clamp is also known as a carriage maker's clamp (Schuler 1973: 30-31) or handscrew clamp (Bureau of Navy Personnel 1973: 53,54).

Pintle (1 specimen)

A small L-shaped object with a point on the long arm and a cylindrical shaft on the short arm used to support a strap hinge.

Hook (2 specimens)

Small segments of polished hooks similar in size to a hay or meat hook.

\section{Unidentified Fastener (2 specimens)}

One specimen is a rectangular sheet with a lunate perforated tab and the other is a zinc-headed nail of unknown function.

Glazer's Point (7 specimens)

In the glazing of windows, it is necessary to hold the pane in place while the putty or caulk is applied and sets. These items are small triangular pieces of thin sheet iron.

Cinch Buckle (1 specimen)

Ring present only; tong missing.

Bit (1 specimen)

Horseshoe (2 specimens)

Door Knob Spindle (l specimen)

The specimen consists of a hollow spool attached to a square cross section shaft by an iron rivet.

Door Knob Tumbler (1 specimen)

A medium ( $5 \mathrm{~cm}$. long) C-shaped iron object with a projection on the back side of the $\mathrm{C}$ and perforations on the two ends. 
Door Lock Strike Plate (1 specimen)

A cast half-boxlike item morticed into the door jamb; also known as a door-lock keeper (Forney 1974: 405).

Door Lock Plate (2 specimens) (Fig. 9f)

One specimen is the exterior face of a box lock measuring $94 \times 74 \times 21 \mathrm{~mm}$. in two fragments. It is open on one end and the face is perforated for the door knob spindle. The second specimen is the interior face having three rectangular perforations and an interior hooked projection. It measures $97 \times 72 \times 6 \mathrm{~mm}$. with projections on one side.

Key (1 specimen)

The item is an iron shaft with a figure-eight loop attached to one end. The tooth segment is broken off.

Chain ( 3 specimens)

tricted centers.

Segments of figure-eight links or loops within cons-

Ring (6 specimens)

Small wire rings of unknown function.

D Buckle (2 specimens)

Buckles with a vertical straight shaft with a wire tongue attached and a D-shaped body; the functions are multiple.

Rectangular Buckle (7 specimens)

A buckle with a rectangular form and a wire tongue attached to one of the long sides.

Buckle Fragment (3 specimens)

Fragments of buckles retaining a portion of the tongue or angle between post and body.

Strap Hinge (1 specimen)

A small segment of a forged thick strap doubled on itself to form a cylindrical receptacle for a pintle shaft. 
Butt Hinge (1 specimen)

Although it is too encrusted with oxidation residues to determine the exact type of hinge, it is clear that the item is a shutter or screen door hinge.

Shaft (3 specimens)

A cylindrical rod of unknown function.

Mill Bastard File (1 specimen)

The specimen consists of the tang, heel and the body excluding the point. It is not possible to determine the cut, but it is assumed to be single bastard cut.

Galvanized Roofing Nail (I specimen)

A small segment of corrugated galvanized iron normally used in roofing barns and other outbuildings, but also used on occasion to roof houses.

I Bracket (1 specimen)

The specimen is an L-shaped bracket (not a corner brace) used in supporting shelving.

Small Gear (1 specimen)

A small, toothed disc of unknown function; oxidation residues prevent further description.

Swivel Loop (3 specimens)

An iron loop attached to a cast iron sleeve which attaches to a cable; the loop can swivel in the sleeve.

Valve Adjustment Screw (2 specimens)

Split Tube (6 specimens)

These items of unknown function are short, cast iron tubes closed with a rounded end on one end and an exterior ring on the opposite end.

Tube (8 specimens)

A narrow sheet iron tube of unknown function. 
Figure 9. Artifacts

a. Toy Pistol

b. Cast Iron Andiron, $\frac{1}{2}$ actual size

c. Brass Finial

d. Pen or Pocketknife with Mother of Pearl Handle

e. Bone Toothbrush Handle Engraved "PARIS FRANCE"

f. Iron and Brass Door Lock Plate, $\frac{1}{2}$ actual size 
Figure 9
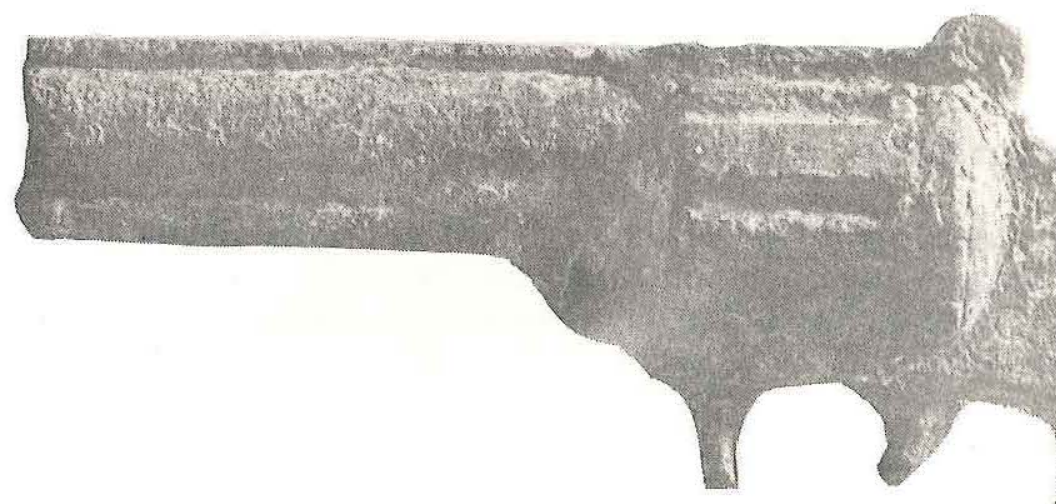

to.

a
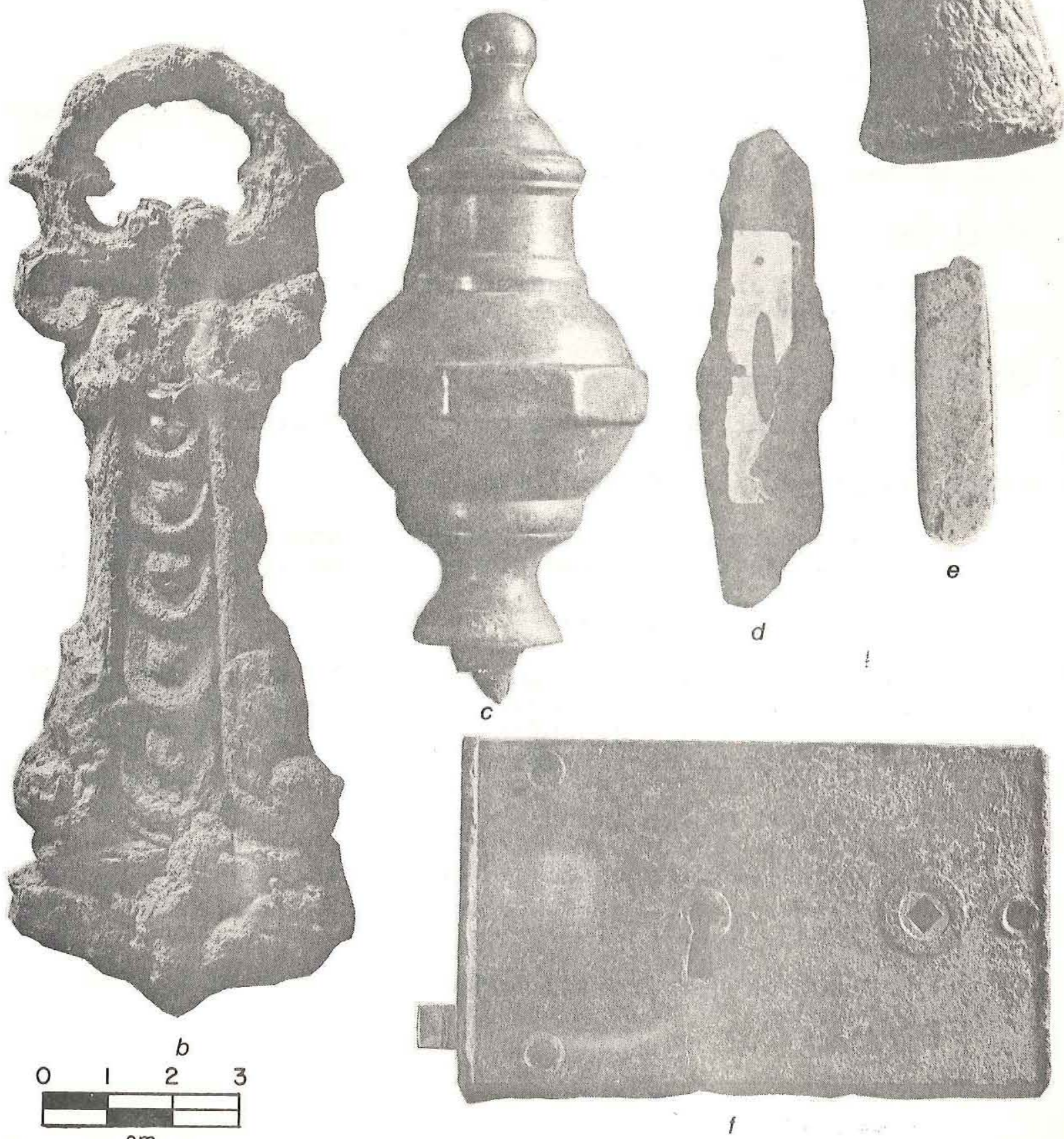
Water Pipe (2 specimens)

One-inch cast iron galvanized water pipe segment.

Three iron water pipes were encountered during the excavations and not removed. These have been almost universally replaced by P.V.C. plastic pipes.

\section{Caster (2 specimens)}

One specimen consists of the shank and supports for the axle and the other is complete.

Faucet Part (3 specimens)

One specimen consists of an iron butterfly handle and threaded copper shaft flattened on two sides; the others consist of smaller iron fragments.

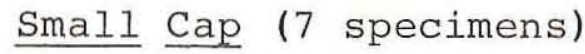

Small flat discs of sheet iron crimped on the edge; function unknown.

Stove Burner Fragment (1 specimen)

A fragment of the edge of a burner plate.

Stove Lid Lifter (1 specimen)(Fig. 8a)

The specimen is a perforated lozenge-shaped cast iron object having one end tapered for insertion into a stove lid.

Andiron ( 1 specimen) (Fig. 9b)

The large cast iron specimen is the upper two-thirds

of the front portion of an andiron. It lacks the two cast legs on the lower end and a brass finial. It is similar to one found at Fort Lancaster (Black 1976: Fig. 45).

Skillet Fragment (4 specimens)

A small section of rim of a skillet.

Bucket Fragment ( 6 specimens)

A section of wire rim and crimped seam of the body and body sherds. 
Bucket Handle (2 specimens)

bucket handle.

Sections of wire arc of appropriate gauge to be a

Handle (3 specimens)

Wire loops and fragments of attached sheet iron possibly from galvanized iron wash tubs. The loops are flattened horizontally.

Spoon (2 specimens)

One complete specimen is a plain silver-plated iron spoon $57 \mathrm{~mm}$. long. The handle is expanded into a lozenge shape. The other specimen is a spoon bowl.

Table Knife (1 specimen)

This specimen is a complete iron knife lacking only the attached organic handles. The blade is broad with parallel edges and a rounded tip. The handle, likewise, has parallel edges and is flat on the butt; it is perforated for rivets.

$$
\begin{array}{lr}
\text { Total Length: } & 226 \mathrm{~mm} . \\
\text { Blade Length: } & 140 \mathrm{~mm} \text {. } \\
\text { Blade Width: } & 20 \mathrm{~mm} .
\end{array}
$$

Butcher Knife (1 specimen)

Apparently the tip end of a knife with the curved underblade and angled upper edge. This may, however, be a segment of strap iron eroded into this shape.

Cylindrical Can (75 specimens)

Numerous fragments; no upper lid segments were recognized so it cannot be determined if they are early or late cans.

Sardine Can (1 specimen)

One complete can with several fragments.

Crown Cap (20 specimens)

Patented in 1891 (Lief n.d.: 17-19). 
Cocoa Lid ( 7 specimens)

Fragments of disc-shaped iron sheet with the edge crimped vertically and everted into a roll.

Buttons (41 specimens)

I. Flat discs with a central depression perforated with four holes.

Diameter

$$
\begin{array}{ll}
13 \mathrm{~mm} . & 1 \text { specimen } \\
14 \mathrm{~mm} . & 1 \text { specimen } \\
15 \mathrm{~mm} . & 3 \text { specimens } \\
16 \mathrm{~mm} . & 1 \text { specimen } \\
17 \mathrm{~mm} . & 1 \text { specimen } \\
18 \mathrm{~mm} . & 4 \text { specimens }
\end{array}
$$

II. Disc buttons crimped to form a hollow item.
Diameter:
$15 \mathrm{~mm}$.
2 specimens
$17 \mathrm{~mm}$.
1 specimen
$18 \mathrm{~mm}$.
1 specimen
$19 \mathrm{~mm}$.
2 specimens
$20 \mathrm{~mm}$.
1 specimen
$25 \mathrm{~mm}$.
1 specimen

III. Covered buttons; these consist of flattened discs covered with cloth fitting into a smaller flat disc.
Diameter:
$13 \mathrm{~mm}$.
1 specimen
$14 \mathrm{~mm}$.
1 specimen
$17 \mathrm{~mm}$.
2 specimens
$18 \mathrm{~mm}$.
1 specimen
$19 \mathrm{~mm}$.
1 specimen
$20 \mathrm{~mm}$.
1 specimen

IV. Doughnut-shaped discs having a hollow center.
Diameter:
$16 \mathrm{~mm}$.
1 specimen
$27 \mathrm{~mm}$.
1 specimen

V. Flat discs with raised rims and omega $\Omega$ attachment.
Diameter:
$13 \mathrm{~mm}$.
$18 \mathrm{~mm}$.
$19 \mathrm{~mm}$.
1 specimen
1 specimen
1 specimen 


\section{Button Cover (4 specimens)}

These are small iron caps with flat faces and shallow scotias expanding into narrow tori.

Overall Stud (1 specimen)

A reel-shaped stud covered with a flat brass head having the following embossed letters:

\section{HEAD}

\section{LIGHT}

Shoe Tap (1 specimen)

A lunate iron sheet perforated for nails.

Scissors (1 specimen)

The scissors appear to be plain embroidery scissors. There is no fancy design on any part. The estimated length is $110 \mathrm{~mm}$.

Pen Nib (53 specimens) (Fig. 8g-h)

The pen nibs are of two types, crow quills and falcons (2 specimens). The crow quills are parallel-sided while the falcons have a relatively narrow shank and are expanded midway between the point and butt of the shank.

Pistol (1 specimen) (Fig. 9x)

This specimen is a two-part mold cast iron toy pistol. Galvanized Cover ( 1 specimen)

The specimen is a rectangular sheet of galvanized iron crimped on both short ends. One short end is cut to form a triangle with the crimp as the base.

$\begin{array}{lr}\text { Length of body: } & 108 \mathrm{~mm} . \\ \text { Length of square crimp: } & 7 \mathrm{~mm} \text {. } \\ \text { Length of triangular crimp: } & 38 \mathrm{~mm} . \\ \text { Width: } & 72 \mathrm{~mm} \text {. } \\ \text { Total length: } & 153 \mathrm{~mm} .\end{array}$


Sheet Iron (5266 specimens)

Too fragmentary for identification.

Strap Iron (218 specimens)

Too fragmentary for identification.

Chunk Iron (1248 specimens)

Too fragmentary for identification.

Unidentified Object (5 specimens)

Coat Rack Bracket (2 specimens)

S-shaped brackets with a small knob on one end and flattened on the opposite end for attachment to a post.

ZINC

Sheet Flashing (44 specimens)

The fragments are thin sheets presumed to have been used as flashing for chimneys, stove pipes, etc.

Canning Jar Closures (2 specimens)

Sherds of threaded cap from canning jars.

Harmonica Reed Fragments (6 specimens)

Bases and brass reeds; all fragmentary.

Toothpaste Tube (3 specimens)

The threaded mouth and shoulder of a tube; possible toothpaste or oil paint.

Tube ( 1 specimen)

A fragment of thin narrow tubing; function unknown.

PEWTER

Shoe (1 specimen)

The specimen is a cast object in the shape of a shoe. It is suggested that this item may be a Monopoly piece 
deposited during or after the Depression in the late 1930s or early 1940s.

Sheet (4 specimens)

Too fragmentary for identification.

\section{BRASS}

Loop Fastener (1 specimen)

The item is a flattened wire looped and looped on the two ends; function unknown.

\section{Escutcheon (1 specimen)}

The small brass escutcheon (silver-plated) is a small plate covering a lock hole and perforated by two holes for nails. The shape is lozengelike, slightly lunate, with lobes to accommodate the nail holes. A stamped floral motif with a pebbled background is on the face.

Figure-8 Chain ( 3 specimens)

Small chain links (jewelry) formed by segments of wire forming loops with a constricted cantor; one specimen is two and one-half links, one is a full link and one is a link fragment.

Clasp (1 specimen) (Fig. 8c)

This specimen consists of a flattened wire loop with two tabs crimped on the long sides of the wire and held by sets of three iron rivets. The tabs are rectangular with a tab opposite the crimp and with triangles cut out of the rectangle to form an $\mathrm{X}$. The face is decorated with dots, circles and swirls. The rear consists of a bell-shaped strip riveted to the front in three places.

\section{Adjustment Screw Head (18 specimens)} broken off.

These are knurl-edged flat discs with the screws

Rivet (2 specimens)

One specimen is a flat head tapered shank specimen one-half inch long (Montgomery Ward Co. 1965: 405). Another 
specimen is a flat tinner's head clinch rivet whose shank is expanded into tabs.

Washer (3 specimens)

A flat perforated disc, possibly a riveting burr.

Swivel Chain (1 specimen)

A small tube clamped on two loops which are attached to a $14 \mathrm{~mm}$. long flat wire doubled back on itself. The effect is a short tube with loops at either end which are free to turn. The length of the tube is $9.6 \mathrm{~mm}$. The function may have been associated with ringed sinkers or hook swivels (Montgomery Ward Co. 1965: 494).

Bra Hook (1 specimen)

Eye Hook (2 specimens)

Bootlace Hook (1 specimen)

Suspender Buckle (1 specimen)

Garter Fastener (3 specimens)

Garter Buckle (4 specimens)

A buckle formed of one oval and two rectangular loops of wire and a tab with the inscription:

BOSTON GARTER

PAT. 7.6.97 (reverse)

VELVET GRIP

T C $4 \quad 30 \quad 54$

$\begin{array}{llllll}12 & 31 & 44 & \& & 67\end{array}$

Buckle (4 specimens)

One specimen is a rectangular flattened wire with a flattened wire tongue 22.5 x $13 \mathrm{~mm}$., while the second specimen is an oval with two strips punched out to make a central bar. It measures $35 \times 11.5 \mathrm{~mm}$. A third specimen is similar to the second but has a tab on one long side crimped to enclose receiving wires. Inscribed:

PAT

FEB 11, 1897 
The final specimen is an embossed keystone shape with a dome-shaped top. Cut out filagree occupies the central area of the keystone shape. A perforated rectangular tab at the base of the keystone apparently served as the base for attachment on the corners. Gold plating is visible on segments of the artifact.

\section{Clothing Snap (18 specimens)}

One specimen is the knob base of a snap while another is a snap grommet. A third specimen consists of both grommet and snap knob. Two specimens are the snap buttons serving the same function as the grommets. One has a half moon and willow motif stamped onto the face, and the other has a bee surrounded by a circle of dots. The sixth specimen is both the button and knob. The obverse face of the button is stamped with a four-pointed star with dots equidistant between the points and a circular border of dots. The reverse face is stamped "C.F. Co * JFC ." The knob base is stamped:

MADE IN FRANCE

PAT $11 \quad 16 \quad 89$

The remaining specimens are the grommet segments of the fasteners.

\section{Clothing Fastener (2 specimens)}

One is a subtriangular sheet with two rivets at the base and a keyhole perforation at the apex. A second specimen is a sheet, circular in form, with a crimped-over pronged tab. The prongs are inserted into slots into a lozenge-shaped piece forming the back. The face has a curvilinear motif surrounded by a border of dots.

\section{Button (28 specimens)}

I. Stamped buttons. These buttons are made from a disc of brass with the shape and lettering stamped then perforated. One specimen has a flat depressed center with two holes. The second, larger specimen has a concave depressed center with four holes. Around the rim on the face are the words:
Diameter:
$12.8 \mathrm{~mm}$. $16.4 \mathrm{~mm}$.

\section{- BEST - RING - EDGE}


II. Sheet brass stamped with a design; crimped over a flat back; omega wire fastener.

A. A U.S. military general service button similar to Groups 5 and 6 at Fort Lancaster (Clark 1975: 289, 290). The button is stamped with a line eagle, head to the right, five-leaf olive branch in its right talon and three arrows in its left talon; raised line spade shield. Maker's mark: SCOVILL MFG CO. WATERBURY .

Diameter: $\quad 20.0 \mathrm{~mm}$.

B. Three specimens of pebble-textured globes on a slightly conical back and omega fastener.

Diameter: $\quad 12.5 \mathrm{~mm}$.

C. One dome-shaped dot pattern gilded over; flat back and omega shank.

Diameter: $\quad 11.5 \mathrm{~mm}$.

D. One bell-shaped pebbled face on flat back with omega shank.

Diameter: $\quad 11.5 \mathrm{~mm}$.

E. One flat face center dot with surrounding notched ring then ring of dots and a rimnotched ring; flat back and omega shank.

Diameter: $\quad 13.6 \mathrm{~mm}$.

III. Sheet brass crimped over base with raised slot for fastener.

A. A simple cap over the slotted base (3 specimens). Diameter: $\quad 8.3 \mathrm{~mm}$.

$12.4 \mathrm{~mm}$. (2 specimens)

B. An elaborate brass cap over a slotted iron base (2 specimens) (Fig. 8i-j). 
IV. Snap cover button in plain dome shape over a grommet (1 specimen).

$$
\text { Diameter: } \quad 12.0 \mathrm{~mm} \text {. }
$$

V. Cast flat button with alpha or loop shank. One specimen has a depressed oval center with a raised star over an anchor on a lined background. Around the star are the letters "---ERENSIA" (Fig. 8t).

The second specimen is a concave disc.

$$
\begin{aligned}
& \text { Diameter: } \quad 15.4 \mathrm{~mm} \text {. } \\
& 17.7 \mathrm{~mm} \text {. }
\end{aligned}
$$

VI. Covered buttons (8 specimens).

A. This subgroup consists of a doughnut-shaped back with a depressed ring crimped over covered with cloth.

Diameter: $\quad 14.6 \mathrm{~mm}$. (2 specimens)

B. A flat back and alpha shank with a flat crimped top covered with cloth (l specimen).

Diameter: $\quad 14.6 \mathrm{~mm}$.

C. A truncated cone with slot base with a ring crimped over; covered with cloth (1 specimen).

Diameter: $\quad 13.4 \mathrm{~mm}$.

D. A hollow, doughnut-shape covered with cloth. It has a large aperture in the base to receive a disc and alpha shank.

Diameter: $\quad 18.0 \mathrm{~mm}$.

E. A flat disc with wire shank crimped over an iron dome-shaped cover.

Diameter: $\quad 14.0 \mathrm{~mm}$.

F. A flat iron disc with wire shank with crimped dome-shaped cover.

Diameter: $\quad 19.8 \mathrm{~mm}$. 
G. A brass disc perforated for a wire omega shank and crimped for iron button cover.

Diameter: $\quad 12.0 \mathrm{~mm}$.

VII: A disc or flat doughnut-shaped stamped brass cover with curvilinear hatching crimped over an iron back with wire shank (3 specimens).

Diameter: $\quad 14.0 \mathrm{~mm}$.

$16.2 \mathrm{~mm}$.

$16.5 \mathrm{~mm}$.

Button Covers (4 specimens)

Dome-shaped brass discs.

Strap Clip (1 specimen)

A rectangular sheet of brass crimped on one long edge, fatigue-broken on the other long edge. The face has a semitubular stamped boss opened on the ends; function is unknown.

$$
\begin{array}{ll}
\text { Length: } & 29.0 \mathrm{~mm} \\
\text { Width: } & 20.0 \mathrm{~mm} .
\end{array}
$$

Thumb Tack (8 specimens)

The brass heads of wire shank tacks.

Straight Pin (5 specimens)

Thimble (2 specimens)

Common sewing thimbles.

$\underline{\text { Tab }}$ (1 specimen)

A thin, narrow sheet of brass with a perforation in one end. The long edges expand slightly; one end is broken and the other is cut into a triangular shape. The perforation is at the triangular end.

$$
\begin{array}{lr}
\text { Length: } & 15.0 \mathrm{~mm} . \\
\text { Width: } & 6.7 \mathrm{~mm} .
\end{array}
$$

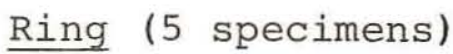
function.

Wire rings, small (ca. $12 \mathrm{~mm}$. diameter) of unknown 
Headed Split Tube (1 specimen)

The specimen is an $11 \mathrm{~mm}$. diameter, $24 \mathrm{~mm}$. long tube slightly expanded to a small, narrow ring on one end and crimped over a notched iron ring $18 \mathrm{~mm}$. in diameter, $3 \mathrm{~mm}$. thick. The tube has a narrow perforation from near the top to near the bottom. The function is unknown.

Threaded Tube with Flanges (2 specimens)

Both specimens are short cylinders with everted lips on one end and a square flange on the other. Both have internal threads. The function is unknown.

Candlestick Holder (1 specimen) (Fig. 8d)

The specimen is a brass ring-shaped handle for a candlestick holder. The ring has a loop-shaped attachment to the holder, a flared thumb rest and a rectangular tab. It is very similar to a specimen from the Joseph R. Brown House in Minnesota (Lindeman and Nystuen 1969: 39, Plate 24).

Electrical Fitting (3 specimens)

One specimen is a small segment of the brass fitting of an electrical socket; another is a small part of an arc with squared and chamfored corners and two plain slotted round-headed machine screws. The third specimen is a fragment of the interior brass tab of a plug.

Fuse Base (2 specimen)

Small rectangular sheets with horizontal tabs on both crimped ends.

Solder (1 specimen)

A droplet of brass solder.

Tube ( 1 specimen)

A crimped sheet of brass forming a tube $28 \mathrm{~mm}$. 1ong and approximately $20 \mathrm{~mm}$. in diameter. Function is unknown.

Lock Plate (2 specimens)

One specimen is a small rectangular sheet of brass perforated for nails and by a small keyhole, and the other is 
oval with two rivets at the top.

Key (2 specimens)

One specimen is a flat key with a round head stamped

with ${ }_{\mathrm{ST}}^{\mathrm{RD}} \mathrm{AR}$ and the other is a fragment of the toothed portion.

Caster (1 specimen)

A complete brass caster apparently with iron bearings.

Mechanical Pencil Tube (1 specimen)

A small segment of the exterior stamped tube of a mechanical pencil.

Eraser Sleeve ( 8 specimens)

- One specimen retains a portion of the wood and graphite pencil and eraser; another retains a part of the eraser.

Sprinkler Head (I specimen)

Cartridges (51 specimens)

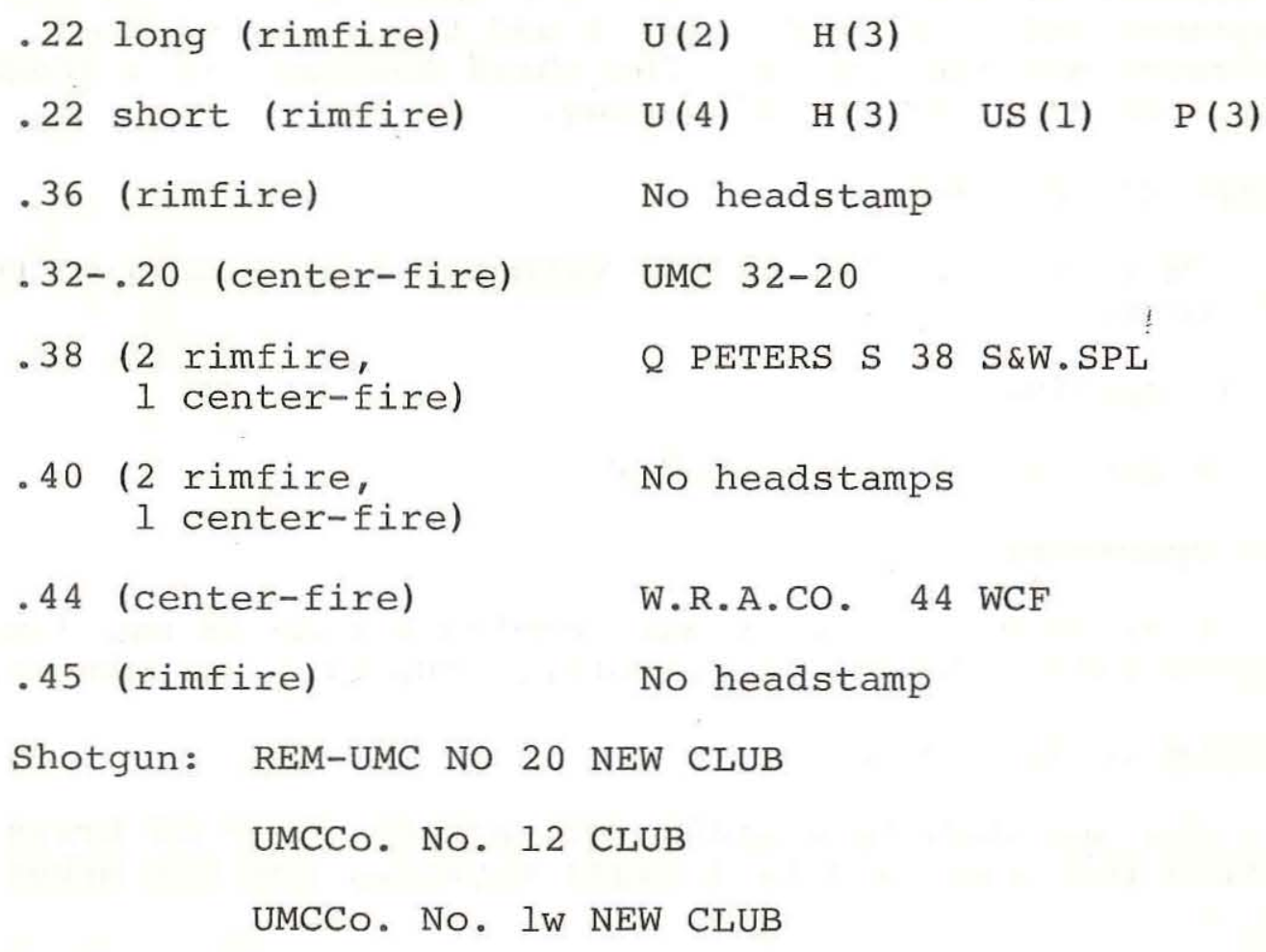


The headstamps help date cartridges in some cases and show points of origin.

U

Union Metallic Cartridge Co., 1867-1911; Remington Arms - UMC 1911-1921; and Remington Arms Co. 1921 to present, Bridgeport, Connecticut

$\mathrm{H}$

Winchester Repeating Arms Co., New Haven, Connecticut

F

Federal Cartridge Corporation, Minneapolis, Minnesota

P

Peters Cartridge Co., Kings Mills, Ohio

US

U.S. Cartridge Co., Lowell, Massachusetts, 1869-1936

UMC $.32-.20$

Union Metallic Cartridge Co., Bridgeport, Connecticut, 1867-1911.

Q PETERS 38 S\&W SpL Peters Cartridge Co., Kings Mills, Ohio; Q s signifies Quick Shot powder

WRA CO. 44 WCF

Winchester Repeating Arms Co., New Haven, Connecticut

REM-UMC

Remington Arms, Union Metallic Cartridge Co. 1911-1920; then Remington Arms Co. after 1920 (White and Munhal1 1963)!

Lamp Case Door Holder (1 specimen)

The specimen is shaped like a French curve template with a screw perforation on one end. A nearly identical specimen is illustrated by Forney (1974: 482, Fig. 769).

Lamp Globe Holder ( 6 specimens)

These sherds are all part of a brass, truncated case with a series of perforated holes near the base and the upper portion formed by a series of stamped filagree tabs to hold the lamp chimney. 
Lamp Burner (2 specimens)

The first specimen is a fragment of a kerosene burner similar to the sun burner; the other consists of a lamp burner perforated by two tubes and is a whale oil burner.

Lamp Burner Ring (1 specimen)

A flat brass ring with four prongs (one broken off) to fit the top of a sun burner.

Wick Screw (2 specimens)

Valve Stem (1 specimen)

A chrome-plated tube stem for a modern bicycle.

Sheet Brass (3 specimens)

Too fragmentary for identification.

Corrugated Sheet (1 specimen)

Too fragmentary for identification.

Strap (14 specimens)

Locket (1 specimen)

This item is a small, heart-shaped sheet with vertical embossed lines radiating from the point. A soldered wire loop $13 \times 14 \mathrm{~mm}$. is on the reverse face.

Unidentified Brass Object (1 specimen)

Finial (1 specimen) (Fig. 9c)

A cast brass object consisting of a series of tori of varying size. The top of the finial is a small globe on a constricted neck which is on a demiglobe based on a torus. A cylindrical shape connects the torus with another which surmounts another demiglobe. The half-globe sits on an octagonal band below which is another demiglobe torus and constricted neck. Virtually identical specimens are illustrated on andirons in antique magazines. 


\section{ALUMINUM}

Flash Bulb Base (17 specimens)

$\underline{\text { Pull }}$ Tab (28 specimens)

Foil (81 specimens)

Screw On Valve (1 specimen)

A knob-shaped head on a short post set on a knurled flange and threaded tube; function is unknown.

NICKLE (4 specimens)
All nickle items are five-cent coins as follows:
Indian Head/Buffalo 1920 (1 specimen)
Jefferson 1940 and 1965 (2 specimens)
Liberty V Nickle 1904 (1 specimen) (Fig. 8f)

SILVER

Dime ( 1 specimen)

Quarter (3 specimens)

Washington Head 1965

Washington Head 1967

Washington Head 1970

Fastener (1 specimen)

A small bent tab which is probably a necklace clasp.

GOLD (2 specimens) (Fig. $6 q, r)$

One specimen is a gold-plated heart pendant with the word "Mamma" on one face; there is a stylized floral border. The second specimen is a small clasp with the letters "NWC" engraved upon it. 
LEAD

Seals (9 specimens) (Fig. 6u)

Two specimens are disc-shaped seals on iron wire having stamped inscriptions as follows:

$$
\begin{aligned}
& \text { No. } 1 \text { - MOP-GRY } 1536 \\
& \begin{array}{l}
1536 \\
\text { No. } 2 \text { - Chas } \\
137
\end{array}
\end{aligned}
$$

The remainder were uninscribed.

Shot (19 specimens)

made.

A variety of sizes is present but no analysis will be

.30-Caliber Bullet (1 specimen)

The bullet is a conical flat base bullet exhibiting rifling marks and impact modification.

Valve Core (1 specimen)

This is a narrow cylinder with a flared base.

$\underline{\text { Knurled Lid (2 specimens) }}$

Function is unknown.

Threaded Lid (1 specimen)

A fragment of a canning or similar lid.

Toy Soldier (1 specimen) (Fig. 8e)

The soldier is a flat cast piece about $28 \mathrm{~mm}$. tall holding an artillery sponge or ladle (Manucy 1949: 74). He is wearing a broad-brimmed hat; the legs are slightly spread apart, the right arm is across the body holding the sponge, and the left arm is raised holding the sponge.

Rectangular Bar ( 3 specimens)

Thin flat rectangular bars; function unknown. 
Solder (2 specimens)

Sections of wire solid core solder.

Droplets (9 specimens)

Sheet (3 specimens)

COPPER

Button (1 specimen)

An $8.6 \mathrm{~mm}$. copper disc-shaped sheet with a geometric design over a flat back; gold-plated.

Ball (1 specimen)

A small copper sphere; function is unknown.

Pennies (15 specimens)

1917S Lincoln head $32,620,000$ minted

1920

$310,165,000$ minted

1929D (2)

$41,730,000$ minted

1933

$14,360,000$ minted

1941

$887,039,100$ minted

1942

$657,828,600$ minted

$1944 \mathrm{D}$

430,578,000 minted, she11 case copper

1952

$186,856,980$ minted

$1954 \mathrm{D}$

$251,552,500$ minted

$1956 \mathrm{D}$

1,098,201,100 minted

1970D

(3)

$2,891,438,900$ minted

1903 Indian Head

$85,094,493$ minted, 95\% copper, $5 \%$ zinc

Mint data from Dinkin, Cohen and Morton (1974). 
Water Pipe (5 specimens)

These are $\frac{1}{4}$-inch tubular pipes.

$\underline{\text { Electrical }} \underline{\text { Connection (2 specimens) }}$

Small T-shaped connections with wings or tabs crimped to receive wire.

Wire (6 specimens)

Insulated copper electrical wire.

Bulldog Head (1 specimen)

A small embossed copper sheet in the form of the head of a bulldog; function unknown.

Alligator Clip (1 specimen)

An electrical toothed clip consisting of two arms on a spring-loaded pivot.

BRONZE (2 specimens)

unknown.

Two small curved sheets of cast bronze; function

GRAPHITE (2 specimens)

These specimens are both pencil leads.

CARBON (1 specimen)

A rectangular sheet of pressed carbon with a threaded white metal bolt through the end.

$\begin{array}{ll}\text { Width: } & 43.0 \mathrm{~mm} \text {. } \\ \text { Thickness: } & 11.0 \mathrm{~mm} \text {. }\end{array}$

This is possibly a portion of a battery core.

WHITEWASH (5 specimens) 
PLASTIC

Masonry Screw Sleeve (1 specimen)

A cylinder of white plastic used in screwing into

wallboard or masonry so that the screw doesn't slip out. The screw expands the plastic.

Electrical Tape (2 specimens)

Electrical Wire Connector (1 specimen)

A snap-type connector.

Electrical Insulation (5 specimens)

Fragments of electrical wire insulation.

P.V.C. Pipe (3 specimens)

Fragments and sections of sprinkler system pipe waste.

P.V.C. Pipe Cap (4 specimens)

Threaded cap to seal the end of P.V.C. pipes.

Plastic Tape (6 specimens)

Narrow plastic tape of unknown function.

Automobile Taillight (2 specimens)

Inflated cones with flanges and screw holes.

Bottle Cap (5 specimens)

Knurled and threaded caps.

BIC Pen Stopper (I specimen)

Stopper (1 specimen)

A small flat flanged bottle stopper.

Stereo Cartridge Holder (1 specimen)

A fragment of an eight-track tape cartridge.

Hard Plastic Sheet (92 specimens) 
Flexible Plastic Sheet (34 specimens)

Potting Labels (5 specimens)

All associated with a modern vegetable garden north of the present kitchen.

Styrofoam (21 specimens)

These specimens are mostly from cups.

Sauce Envelope (I specimen)

A plastic and foil envelope for sauce such as catsup or mustard currently provided in fast food restaurants.

Drinking Straw (13 specimens)

Toothbrush Handle (1 specimen)

Cigarette Filter (24 specimens)

Band Aid (4 specimens)

Plastic Flower (1 specimen)

Bead (1 specimen)

A single white plastic bead cast in a two-part mold. Diameter: $\quad 9.1 \mathrm{~mm}$.

Button (1 specimen)

A slightly conical disc mounted on an iron back and perforated in the center.

Diameter: $\quad 15.6 \mathrm{~mm}$.

Barrette (3 specimens)

Rectangular bars slightly curved with a faceted top and nipple on the back with imbedded wire.

Dol1 Arm (2 specimens)

Small flesh-colored doll arms. 
Frisbee (1 specimen)

A small convex disclike toy included in cereal boxes.

CELLULOID

Template (9 specimens)

Sheet celluloid with rectangular and curvilinear shapes cut out; function is unknown.

Button (3 specimens)

Flat discs with depressed centers having either two or four holes in the center.

Hair Pin (I specimen)

A segment of long-pointed celluloid assumed to have functioned as a part of a hair pin.

CELLOPHANE (37 specimens)

RUBBER

Electrical Fitting (2 specimens)

Fragments of rubber plugs.

Electrical Insulation (10 specimens)

These specimens are pieces of electrical wires.

Gasket (4 specimens)

These are disc-shaped seals.

Conical Washer (1 specimen)

Similar to washers used in water faucets.

Pipe Insulation (17 specimens)

Foam rubber wrapped around air conditioner pipes. 
Threaded Pipe (5 specimens)

exterior.

Small segments of hard rubber pipe threaded on the

Tire Welt (1 specimen)

tire.

A small segment of the welt and tread of an automobile

Fabric-Impressed Rubber (3 specimens)

Sheets of rubber with fabric impressions on one side;

function is unknown.

Shoe Toe Cap (1 specimen)

of a shoe.

A small hard rubber item designed to go on the sole

Shoe Heel (2 specimens)

Comb Teeth (33 specimens)

Button ( 3 specimens)

One is a disc-shaped button with a flat center having

four holes; on the rear are the embossed letters "NOVELTY

RUBBER." The others are undecorated.

CHALK (14 specimens)

Fragments of blackboard chalk.

CORK GASKET (1 specimen)

A disc-shaped cork perforated in the center.

CLOTH (1 specimen)

The specimen is a black cloth rosette.

PAPER

Smelling Salts Tube (1 specimen)

A heavily waxed or paraffin-coated tube of paper with 
a crimped paper cup bottom and lettering on the sides; the lettering is illegible.

Wax Paper (1 specimen)

The type used in cooking.

White Paper (4 specimens)

Letter or typing paper.

Cigarette Filter (1 specimen)

Cup (1 specimen)

The rim of a waxed paper cup with rolled rim.

FIBER PACKING TAPE (1 specimen)

MARBLES ( 10 specimens)

These are all dolomitic limestone spheres.

Diameter:

$$
\begin{array}{ll}
11.0 \mathrm{~mm} . & 17.4 \mathrm{~mm} . \\
13.7 \mathrm{~mm} . & 18.2 \mathrm{~mm} . \\
14.0 \mathrm{~mm} . & 20.0 \mathrm{~mm} . \\
15.0 \mathrm{~mm} . & 20.3 \mathrm{~mm} . \\
16.6 \mathrm{~mm} . &
\end{array}
$$

One specimen was fragmentary and not measurable.

BONE ARTIFACTS

Toothbrush (4 specimens) (Fig. 9e)

These specimens include one handle engraved "PARIS FRANCE;" the remainder are fragments of heads.

Button (6 specimens) (Fig. $8 v$ )

Five specimens are disc-shaped, turned buttons with depressed centers and four holes.

$\begin{array}{lll}\text { Diameter: } & 10.8 \mathrm{~mm} . & 17.8 \mathrm{~mm} . \\ 15.4 \mathrm{~mm} . & 18.0 \mathrm{~mm} . \\ 17.0 \mathrm{~mm} . & \end{array}$


The remaining specimen is a disc-shaped lathe-turned button cover with a diameter of $20.0 \mathrm{~mm}$.

SHELL ARTIFACTS

Button (20 specimens)

Eight specimens are flat discs with four holes.

$$
\begin{array}{lll}
\text { Diameter: } & 7.0 \mathrm{~mm} .(4) & 8.0 \mathrm{~mm} . \\
& 9.8 \mathrm{~mm} . & 9.4 \mathrm{~mm} .
\end{array}
$$

The remainder of these flat discs with four holes are unmeasurable. Six specimens are flat discs with two holes, one with a depressed center and one with a raised center.

$$
\begin{array}{llr}
\text { Diameter: } & 14.0 \mathrm{~mm} .(2) & 9.0 \mathrm{~mm} \\
& 15.0 \mathrm{~mm} . & 12.0 \mathrm{~mm} .
\end{array}
$$

The final specimens are a flat disc shape with a back post.

$$
\text { Diameter: } \quad 10.0 \mathrm{~mm} \text {. } \quad 12.0 \mathrm{~mm} \text {. }
$$

Handle (2 specimens)

Small rectangular segments of pen knife or pocketknife handle insets of mother-of-pearl.

MICA (2 specimens)

Small fragments of sheet muscovite mica.

GUM (2 specimens)

Pieces of chewing gum.

\section{COMPOUND ARTIFACTS}

Chrome-Plated Aluminum Bar (2 specimens)

The function is unknown.

$\underline{\text { Rubber }}$ and Iron Washer (1 specimen) 
Chrome-Plated Copper (4 specimens)

Sheet fragments of unknown function.

Brass/Iron Object (1 specimen)

A short iron shaft with two brass discs. One disc is near the center of the shaft and is featureless; the second disc is notched on two opposite sides and has two posts projecting toward the center disc. Small perforations are present. The function is unknown.

Iron/Compound Handle (1 specimen)

The object consists of a flat shaft with a haft made of an unidentified compound. The shape is a long oval and the material is a dark grey. The function is unknown.

Spark Plug. (1 specimen)

A porcelain cylinder with an iron central rod; this plug is an early 20 th Century specimen.

Glass/Copper Light Bulb Base (2 specimens)

These bases are black glass hollow discs with copper contact plates and interior wires.

Pearl-Handled Pocketknife (2 specimens) (Fig. 9d)

Both specimens have rectangular shell riveted to a brass body and iron blades.

Gold/Glass Ring Set (1 specimen) (Fig. 8w)

The specimen is a small gold-plated rosette with a clear diamond-shaped (faceted cone) glass set into it. The back is flat with a perforation for attachment to a ring.

\section{Denture ( 3 specimens)}

The objects consist of porcelain and silver wire and segments of a denture. One segment includes several teeth and gum while one segment comprises a tooth and gum fragment and another consists only of the tooth.

COAL (382 specimens) 
SLAG (413 specimens)

Coal slag or clinkers.

ANIMAL BONE (3866 specimens)

RANGIA CUNEATA (13 specimens)

PECTIN (14 specimens)

OYSTREA VIRGINICA (238 specimens)

SNAIL (6 specimens)

FISH SCALE (2 specimens)

EGG SHELL (2 specimens)

FLINT FLAKES (37 specimens)

WOOD

Post Fragments (7 specimens)

A very small sample of in-place posts found during the excavation.

Muntin Fragments (2 specimens)

Fragments of the type of muntin presently used on the house; they probably date to one of the renovations of the house. Shingle Fragments (1 specimen)

This specimen is a shake fragment probably removed from the house during reroofing. 


\begin{tabular}{|c|c|c|c|c|c|c|}
\hline & GROUP I & GROUP II & GROUP III & GROUP IV & GROUP V & TOTALS: \\
\hline \multicolumn{7}{|l|}{ CERAMICS : } \\
\hline \multicolumn{7}{|l|}{ Pearlware } \\
\hline Plain body & 122 & 551 & 191 & 165 & 85 & 1114 \\
\hline Plain rim & 4 & 155 & 103 & 60 & 19 & 341 \\
\hline Plain base & 2 & 58 & 26 & 30 & 6 & 122 \\
\hline Plain handle & 1 & 1 & 4 & 6 & 1 & 13 \\
\hline Transfer blue & 5 & 29 & 13 & 7 & 3 & 57 \\
\hline Transfer red & 1 & 3 & 2 & 0 & 0 & 6 \\
\hline Transfer green & 0 & 8 & 0 & 5 & 0 & 13 \\
\hline Transfer brown & 0 & 9 & 3 & 3 & 1 & 16 \\
\hline Transfer brown/hand painted & 1 & 1 & 0 & 5 & 0 & 7 \\
\hline Rim banded & 7 & 2 & 0 & 1 & 1 & 11 \\
\hline Gilt banded & 10 & 9 & 1 & 2 & 1 & 23 \\
\hline Embossed body & 1 & 16 & 1 & 2 & 0 & 20 \\
\hline Embossed rim & 0 & 12 & 2 & 0 & 0 & 14 \\
\hline Black band & 0 & 3 & 0 & 0 & 1 & 4 \\
\hline Banded slip & 0 & 3 & 4 & 0 & 0 & 7 \\
\hline Spatterware & 0 & 1 & 2 & 1 & 0 & 4 \\
\hline Decalcomania & 1 & 9 & 1 & 0 & 1 & 12 \\
\hline Applique & 0 & 1 & 1 & 0 & 0 & 2 \\
\hline Hand painted & 1 & 6 & 1 & 1 & 0 & 9 \\
\hline Maker's marks & 0 & 32 & 13 & $1 \overline{1}$ & 4 & 60 \\
\hline Stencil & 0 & 0 & 0 & 1 & 0 & 1 \\
\hline \multicolumn{7}{|l|}{ Creamware } \\
\hline Plain body & 1 & 13 & 3 & 2 & 1 & 20 \\
\hline Plain rim & 0 & 0 & 1 & 0 & 0 & 1 \\
\hline Plain base & 0 & 1 & 0 & 1 & 0 & 2 \\
\hline Banded slip & 0 & 1 & 0 & 0 & 0 & 1 \\
\hline Enamel Ware & 1 & 13 & 4 & 5 & 1 & 24 \\
\hline Blue Ware & 1 & 9 & 1 & 0 & 0 & 11 \\
\hline
\end{tabular}


TABLE 4: PROVENIENCE CHART, Continued

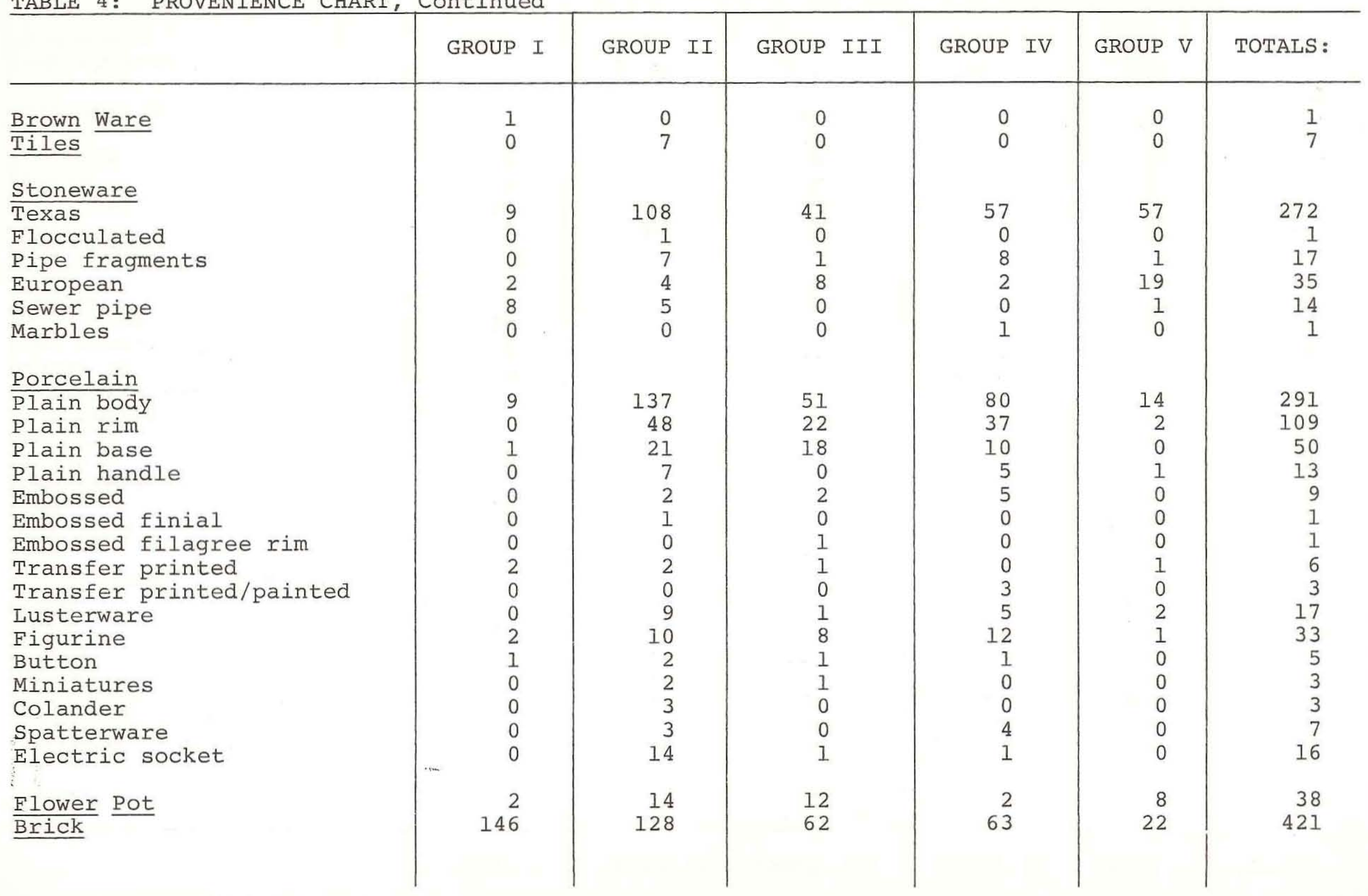


TABLE 4: PROVENIENCE CHART, Continued

\begin{tabular}{|c|c|c|c|c|c|c|}
\hline & GROUP I & GROUP II & GROUP III & GROUP IV & GROUP V & TOTALS : \\
\hline GLASS : & & & & & & \\
\hline Complete bottles & 0 & 1 & 2 & 2 & 0 & 5 \\
\hline Near complete bottles & 0 & 4 & 1 & 0 & 0 & 5 \\
\hline Unbleached & 75 & 1004 & 410 & 450 & 496 & 2435 \\
\hline Manganese & 33 & 293 & 171 & 113 & 69 & 679 \\
\hline Selenite & 231 & 2189 & 751 & 735 & 710 & 4616 \\
\hline Brown & 45 & 394 & 200 & 194 & 369 & 1202 \\
\hline Green & 53 & 212 & 127 & 42 & 153 & 587 \\
\hline Miscellaneous glass buttons & 0 & 16 & 9 & 5 & 0 & 30 \\
\hline Blue & 3 & 34 & 20 & 5 & 4 & 66 \\
\hline Blue opaque & 0 & 15 & 2 & 13 & 0 & 30 \\
\hline Rose & 1 & 0 & 1 & 0 & 0 & 2 \\
\hline Compound rose/white & 0 & 1 & 0 & 0 & 0 & 1 \\
\hline Yellow & 0 & 1 & 0 & 0 & 0 & 1 \\
\hline Amethyst & 0 & 1 & 0 & 0 & 0 & 1 \\
\hline Salt shaker & 0 & 2 & 0 & 0 & 0 & 2 \\
\hline Corrugated panels & 0 & 3 & 0 & 0 & 0 & 3 \\
\hline Drawer pull & 0 & 1 & 0 & 0 & 0 & 1 \\
\hline Lamp reservoir & 0 & 3 & 26 & 0 & 0 & 29 \\
\hline Flash bulb & 14 & 5 & 4 & 0 & 0 & 23 \\
\hline Etched & 0 & 0 & 0 & 1 & 0 & 1 \\
\hline Milk Glass & & & & & & \\
\hline$\overline{\text { Button }}$ & 1 & 14 & 9 & 16 & 7 & 47 \\
\hline Lid liners & 14 & 27 & 4 & 0 & 6 & 51 \\
\hline Bottle & 0 & 0 & 2 & 0 & 0 & 2 \\
\hline Bowl rim & 0 & 3 & 0 & 0 & 0 & 3 \\
\hline Lid & + & 2 & 1 & 1 & 0 & 4 \\
\hline Body sherds & 1 & 65 & 31 & 13 & 3 & 113 \\
\hline Lamp chimney & 350 & 3688 & 1677 & 952 & 299 & 6966 \\
\hline Windowpane & 1456 & 3319 & 2457 & 1047 & 393 & 8672 \\
\hline
\end{tabular}


TABLE 4: PROVENIENCE CHART, Continued

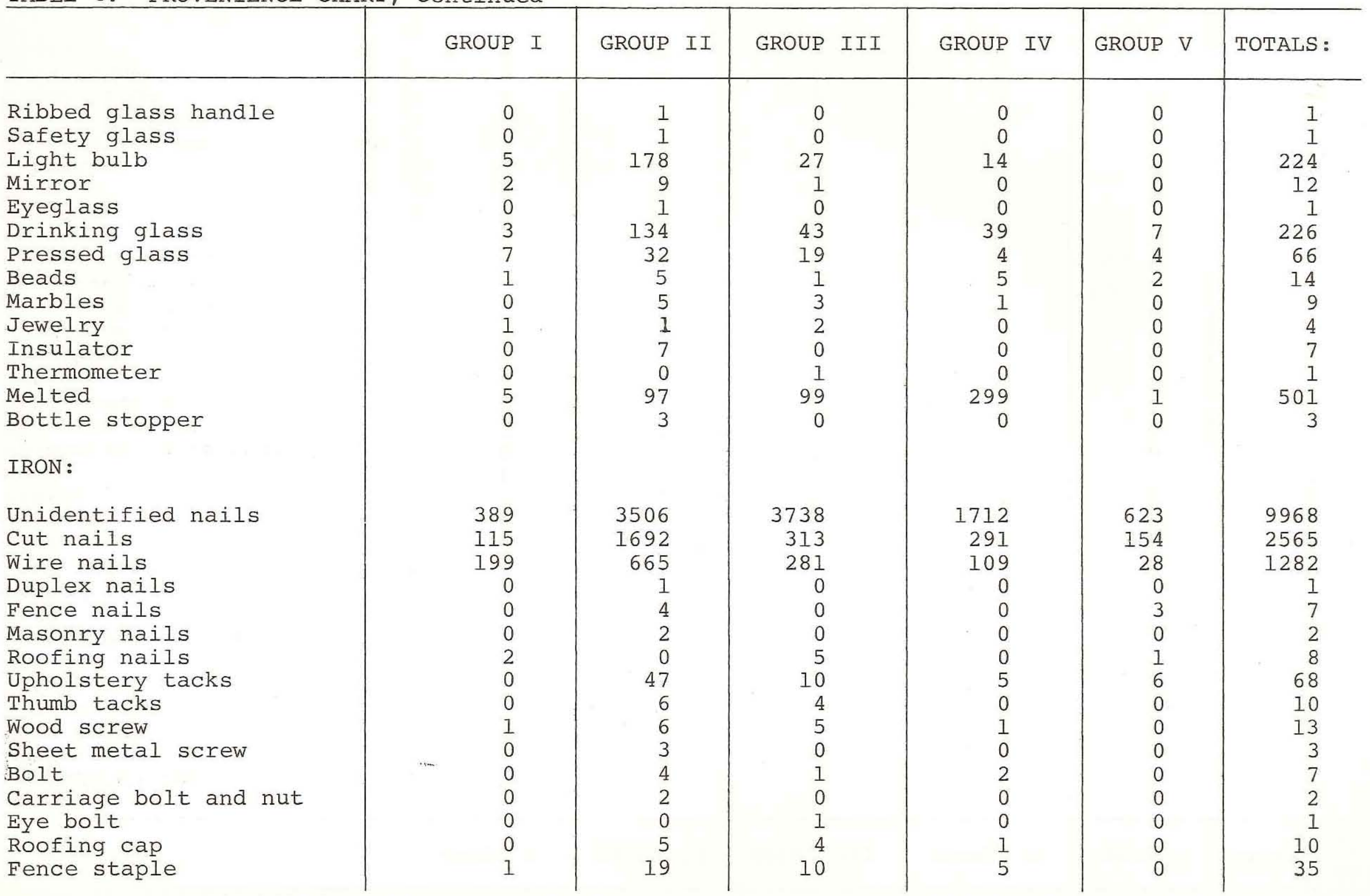


TABLE 4: PROVENIENCE CHART, Continued

\begin{tabular}{|c|c|c|c|c|c|c|}
\hline & GROUP I & GROUP II & GROUP III & GROUP IV & GROUP V & TOTALS: \\
\hline $\begin{array}{l}\text { Corrugated fastener } \\
\text { Washer } \\
\text { Door latch } \\
\text { Window latch } \\
\text { Safety pin } \\
\text { Hat pin } \\
\text { Clothespin spring } \\
\text { Wire } \\
\text { Barbed wire } \\
\text { Coil spring } \\
\text { Clasp } \\
\text { C clamp } \\
\text { Pintle } \\
\text { Hook } \\
\text { Unidentified fastener } \\
\text { Glazer's point } \\
\text { Cinch buckle } \\
\text { Bit } \\
\text { Horseshoe } \\
\text { Door knob spindle } \\
\text { Door knob tumbler } \\
\text { Door lock strike plate } \\
\text { Door lock plate } \\
\text { Key } \\
\text { Chain } \\
\text { Ring } \\
\text { D buckle } \\
\text { Rectangular buckle } \\
\text { Buckle fragment } \\
\text { Strap hinge } \\
\text { Butt hinge } \\
\text { Shaft }\end{array}$ & $\begin{array}{l}0 \\
0 \\
0 \\
0 \\
1 \\
0 \\
1 \\
7 \\
0 \\
0 \\
0 \\
0 \\
0 \\
1 \\
0 \\
0 \\
0 \\
0 \\
0 \\
0 \\
0 \\
0 \\
0 \\
0 \\
0 \\
0 \\
0 \\
0 \\
0 \\
0 \\
0 \\
0\end{array}$ & $\begin{array}{r}2 \\
0 \\
1 \\
0 \\
1 \\
1 \\
1 \\
86 \\
3 \\
0 \\
0 \\
0 \\
1 \\
1 \\
1 \\
4 \\
0 \\
1 \\
1 \\
0 \\
1 \\
0 \\
0 \\
1 \\
1 \\
2 \\
2 \\
2 \\
0 \\
1 \\
0 \\
2\end{array}$ & $\begin{array}{r}0 \\
2 \\
0 \\
0 \\
0 \\
0 \\
0 \\
14 \\
0 \\
0 \\
0 \\
0 \\
0 \\
0 \\
0 \\
1 \\
0 \\
0 \\
1 \\
1 \\
0 \\
1 \\
1 \\
0 \\
1 \\
0 \\
0 \\
4 \\
3 \\
3 \\
0 \\
1 \\
1\end{array}$ & $\begin{array}{l}0 \\
0 \\
0 \\
2 \\
1 \\
0 \\
0 \\
2 \\
0 \\
4 \\
1 \\
1 \\
0 \\
0 \\
1 \\
2 \\
0 \\
0 \\
0 \\
0 \\
0 \\
0 \\
1 \\
0 \\
0 \\
4 \\
0 \\
1 \\
0 \\
0 \\
0 \\
0\end{array}$ & $\begin{array}{l}0 \\
0 \\
0 \\
0 \\
0 \\
0 \\
0 \\
3 \\
0 \\
0 \\
1 \\
0 \\
0 \\
0 \\
0 \\
0 \\
1 \\
0 \\
0 \\
0 \\
0 \\
0 \\
0 \\
0 \\
1 \\
0 \\
0 \\
0 \\
0 \\
0 \\
0 \\
0\end{array}$ & $\begin{array}{r}2 \\
2 \\
1 \\
2 \\
3 \\
1 \\
2 \\
112 \\
3 \\
4 \\
2 \\
1 \\
1 \\
2 \\
2 \\
7 \\
1 \\
1 \\
2 \\
1 \\
1 \\
1 \\
2 \\
1 \\
3 \\
6 \\
2 \\
7 \\
3 \\
1 \\
1 \\
3\end{array}$ \\
\hline
\end{tabular}


TABLE 4: PROVENIENCE CHART, Continued

\begin{tabular}{|c|c|c|c|c|c|c|}
\hline & GROUP I & GROUP II & GROUP III & GROUP IV & GROUP V & TOTALS : \\
\hline $\begin{array}{l}\text { Mill bastard file } \\
\text { Galvanized roofing iron } \\
\text { L bracket } \\
\text { Small gear } \\
\text { Swivel loop } \\
\text { Valve adjustment screw } \\
\text { Split tube } \\
\text { Tube } \\
\text { Water pipe } \\
\text { Caster } \\
\text { Faucet part } \\
\text { Small cap } \\
\text { Stove burner fragment } \\
\text { Stove lid lifter } \\
\text { Andiron } \\
\text { Skillet fragment } \\
\text { Bucket fragment } \\
\text { Bucket handle } \\
\text { Handle } \\
\text { Spoon } \\
\text { Table knife } \\
\text { Butcher knife } \\
\text { Cylindrical can } \\
\text { Sardine can } \\
\text { Crown cap } \\
\text { Cocoa lid } \\
\text { Button } \\
\text { Button cover } \\
\text { overall stud } \\
\text { Shoe tap } \\
\text { Scissors } \\
\text { Pen nib }\end{array}$ & $\begin{array}{l}0 \\
1 \\
0 \\
0 \\
0 \\
1 \\
0 \\
0 \\
0 \\
0 \\
0 \\
0 \\
0 \\
0 \\
0 \\
0 \\
0 \\
0 \\
1 \\
0 \\
0 \\
0 \\
0 \\
0 \\
2 \\
0 \\
0 \\
0 \\
0 \\
0 \\
0 \\
0\end{array}$ & $\begin{array}{r}1 \\
0 \\
1 \\
0 \\
3 \\
0 \\
5 \\
0 \\
1 \\
1 \\
0 \\
1 \\
0 \\
0 \\
1 \\
4 \\
0 \\
0 \\
0 \\
2 \\
1 \\
1 \\
62 \\
0 \\
16 \\
7 \\
12 \\
2 \\
0 \\
0 \\
0 \\
4\end{array}$ & 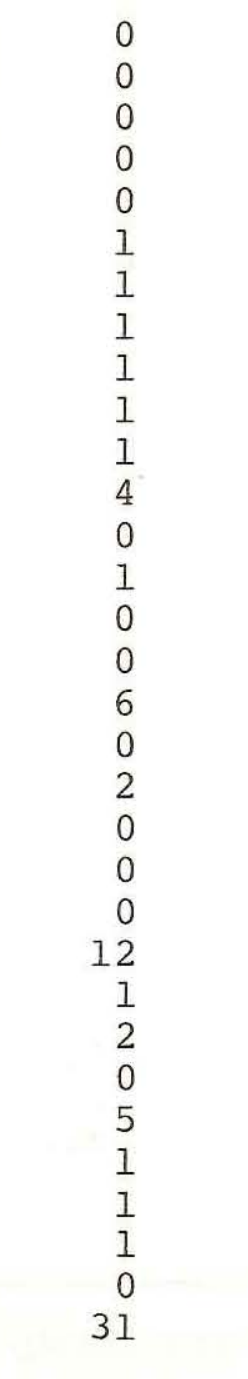 & $\begin{array}{r}0 \\
0 \\
0 \\
0 \\
0 \\
0 \\
0 \\
0 \\
0 \\
0 \\
0 \\
2 \\
1 \\
0 \\
0 \\
0 \\
0 \\
1 \\
0 \\
0 \\
0 \\
0 \\
1 \\
0 \\
0 \\
0 \\
24 \\
1 \\
0 \\
0 \\
0 \\
18\end{array}$ & $\begin{array}{l}0 \\
0 \\
0 \\
1 \\
0 \\
0 \\
0 \\
7 \\
0 \\
0 \\
2 \\
0 \\
0 \\
0 \\
0 \\
0 \\
0 \\
1 \\
0 \\
0 \\
0 \\
0 \\
0 \\
0 \\
0 \\
0 \\
0 \\
0 \\
0 \\
0 \\
1 \\
0\end{array}$ & $\begin{array}{r}1 \\
1 \\
1 \\
1 \\
3 \\
2 \\
6 \\
8 \\
2 \\
2 \\
3 \\
7 \\
1 \\
1 \\
1 \\
4 \\
6 \\
2 \\
3 \\
2 \\
1 \\
1 \\
75 \\
1 \\
20 \\
7 \\
41 \\
4 \\
1 \\
1 \\
1 \\
53\end{array}$ \\
\hline
\end{tabular}


TABLE 4: PROVENIENCE CHART, Continued

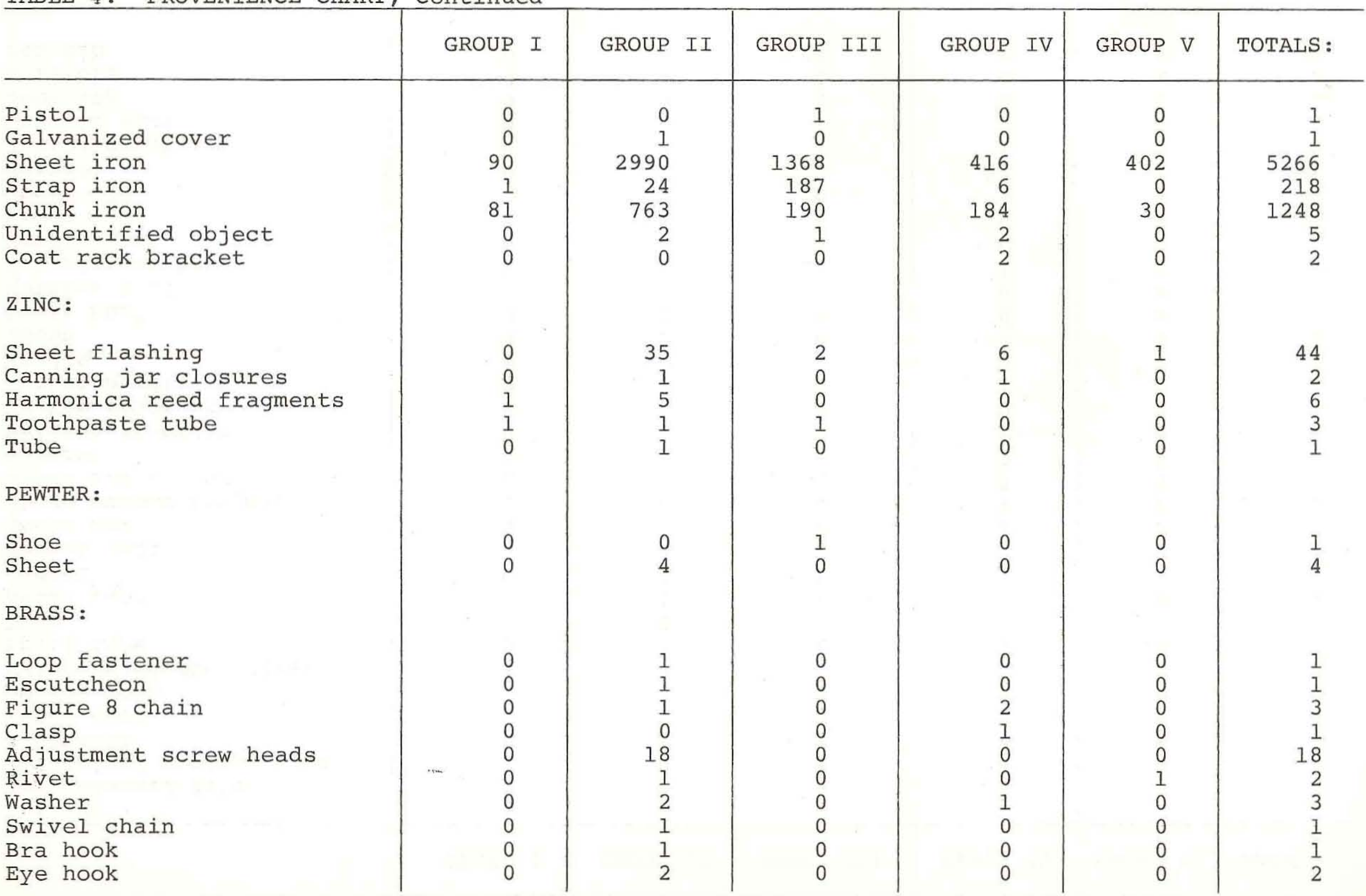


TABLE 4: PROVENIENCE CHART, Continued

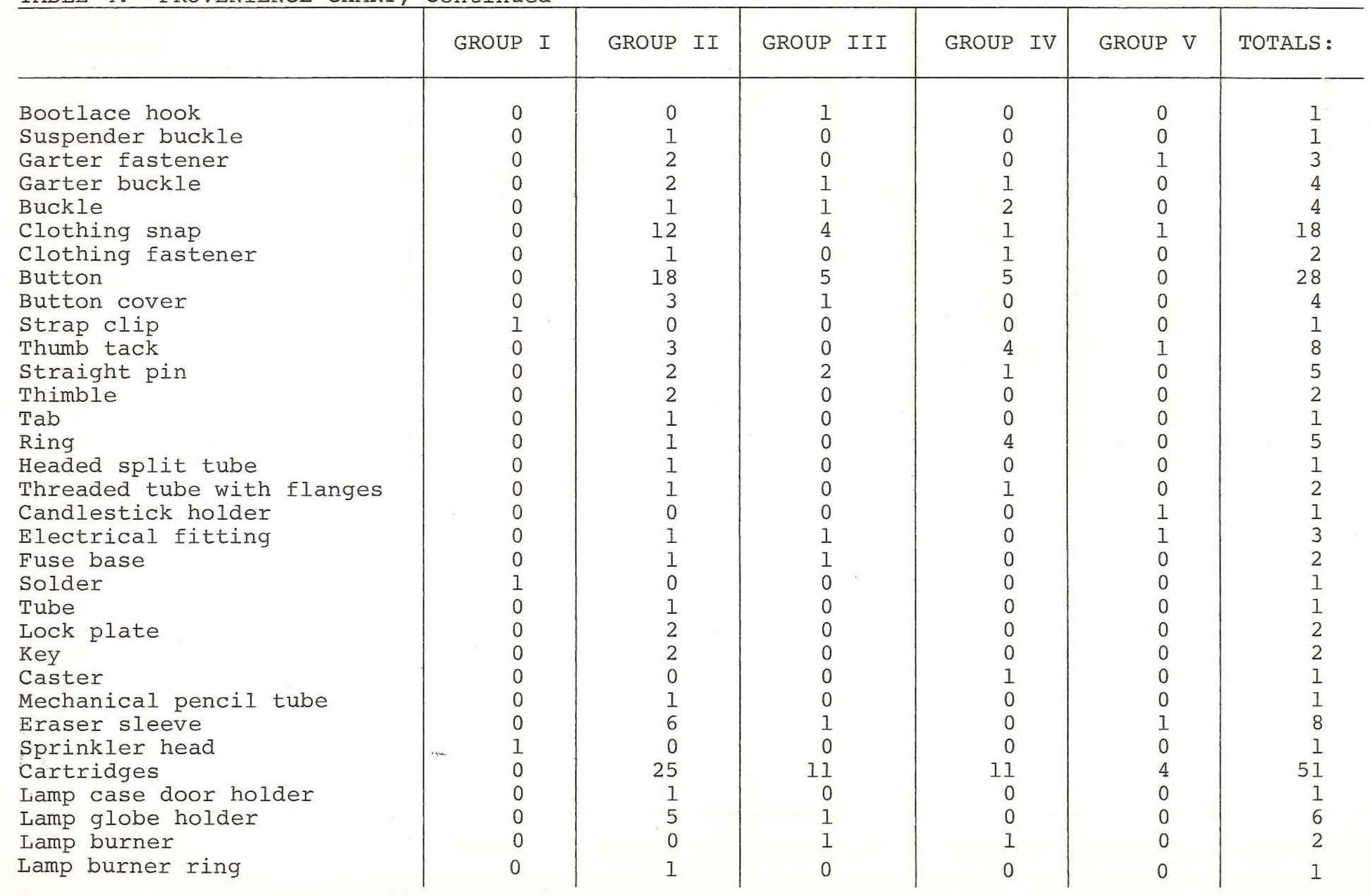


TABLE 4: PROVENIENCE CHART, Continued

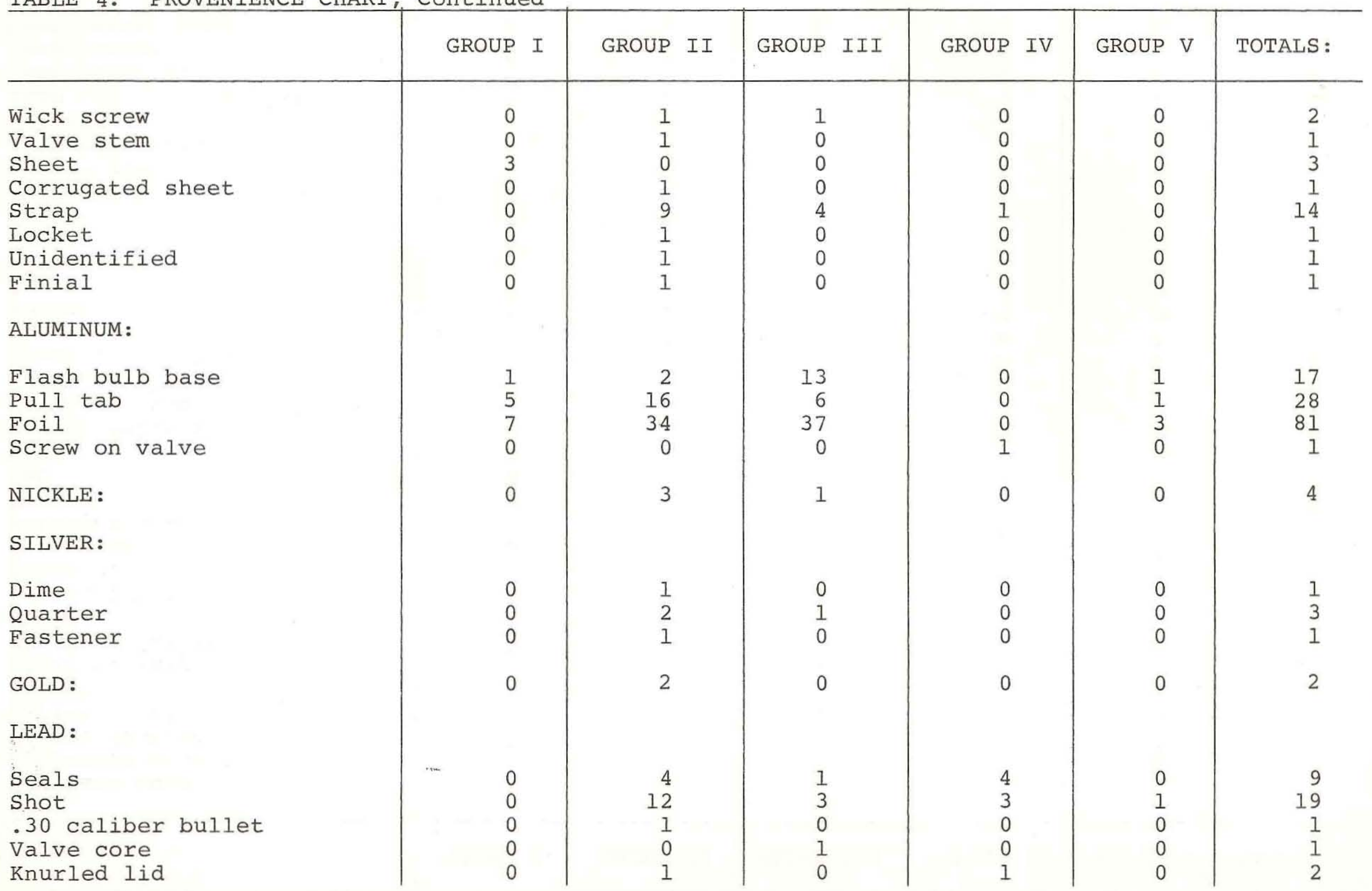


TABLE 4: PROVENIENCE CHART, Continued

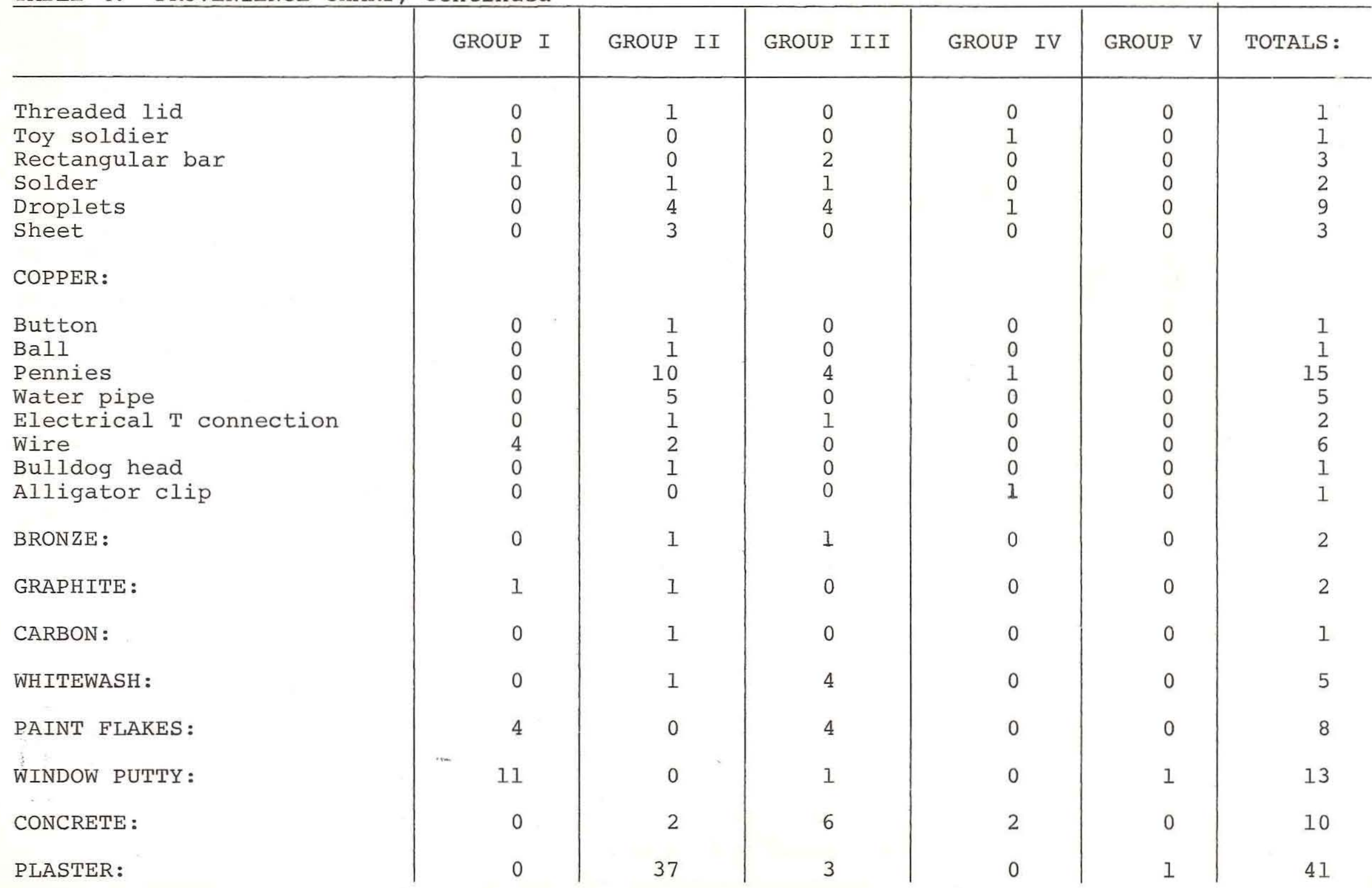


TABLE 4: PROVENIENCE CHART, Continued

\begin{tabular}{|c|c|c|c|c|c|c|}
\hline & GROUP I & GROUP II & GROUP III & GROUP IV & GROUP V & TOTALS : \\
\hline MORTAR : & 0 & 65 & 9 & 0 & 2 & 76 \\
\hline ROOFING COMPOUND: & 1 & 34 & 0 & 1 & 0 & 36 \\
\hline DUCT TAPE: & 14 & 1 & 0 & 0 & 0 & 15 \\
\hline \multicolumn{7}{|l|}{ SLATE: } \\
\hline Sheet & 16 & 157 & 159 & 60 & 17 & 409 \\
\hline Pencil & 3 & 25 & 8 & 14 & 2 & 52 \\
\hline \multicolumn{7}{|l|}{ PLASTIC : } \\
\hline Masonry screw sleeve & 0 & 1 & 0 & 0 & 0 & 1 \\
\hline Electrical tape & 0 & 1 & 0 & 0 & 1 & 2 \\
\hline Electrical wire connector & 1 & 0 & 0 & 0 & 0 & 1 \\
\hline Electrical insulation & 1 & 4 & 0 & 0 & 0 & 5 \\
\hline P.V.C. pipe & 0 & 3 & 0 & 0 & 0 & 3 \\
\hline P.V.C. pipe cap & 3 & 1 & 0 & 0 & 0 & 4 \\
\hline Plastic tape & 0 & 1 & 5 & 0 & 0 & 6 \\
\hline Automobile taillight & 0 & 1 & 0 & 1 & 0 & 2 \\
\hline Bottle cap & 3 & 0 & 2 & 0 & 0 & 5 \\
\hline BIC pen stopper & 0 & 1 & 0 & 0 & 0 & 1 \\
\hline Stopper & 0 & 1 & 0 & 0 & 0 & 1 \\
\hline Stereo cartridge holder & 1 & 0 & 0 & 0 & 0 & 1 \\
\hline Hard plastic sheet & 23 & 45 & 18 & 2 & 4 & 92 \\
\hline Elexible plastic sheet & 0 & 28 & 6 & 0 & 0 & 34 \\
\hline Potting labels & 0 & 5 & 0 & 0 & 0 & 5 \\
\hline Styrofoam & 3 & 17 & 1 & 0 & 0 & 21 \\
\hline Sauce envelope & 0 & 1 & 0 & 0 & 0 & 1 \\
\hline Drinking straw & 1 & 12 & 0 & 0 & 0 & 13 \\
\hline Toothbrush handle & 0 & 0 & 1 & 0 & 0 & 1 \\
\hline Cigarette filter & 4 & 15 & 5 & 0 & 0 & 24 \\
\hline
\end{tabular}


TABLE 4: PROVENIENCE CHART, Continued

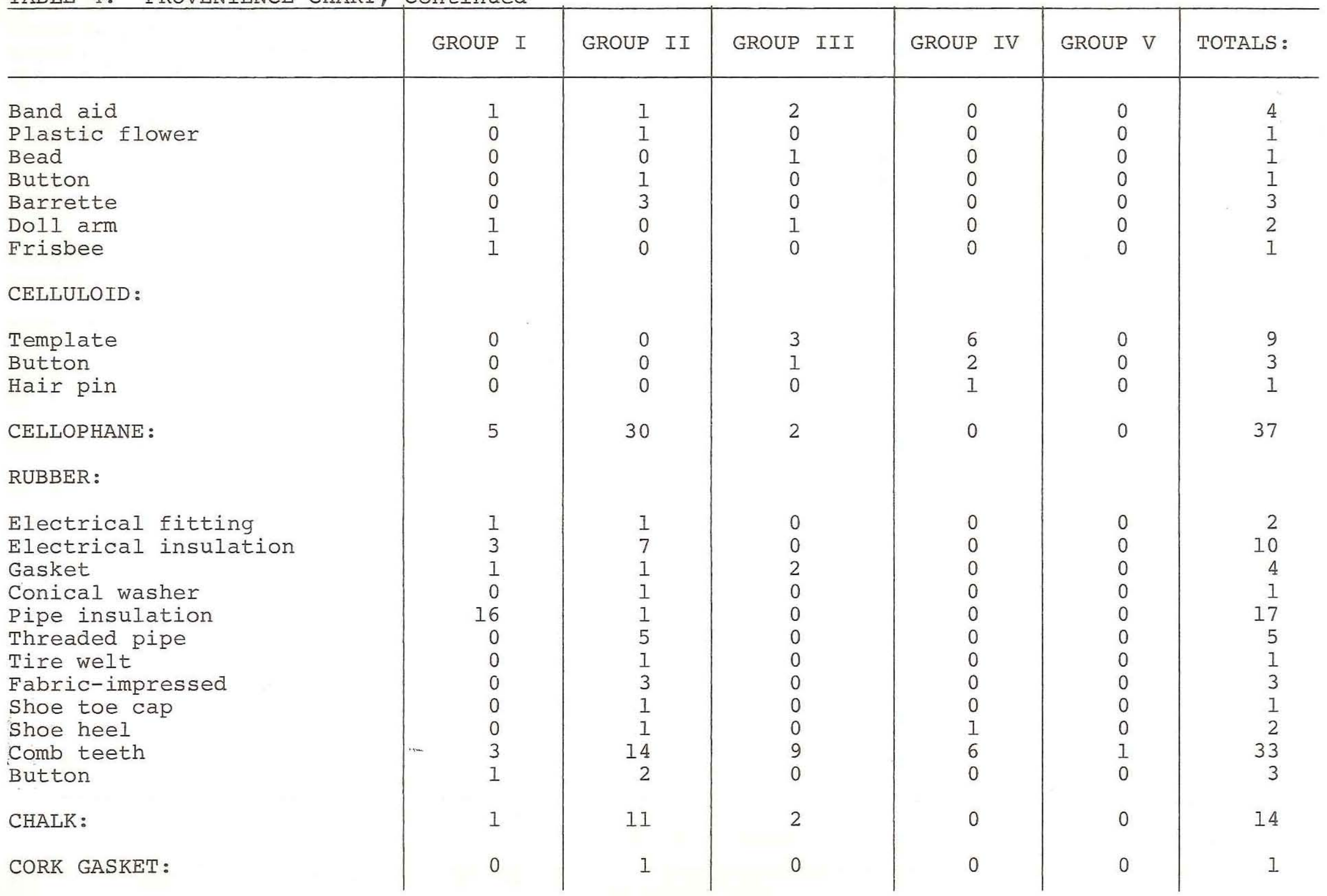


TABLE 4: PROVENIENCE CHART, Continued

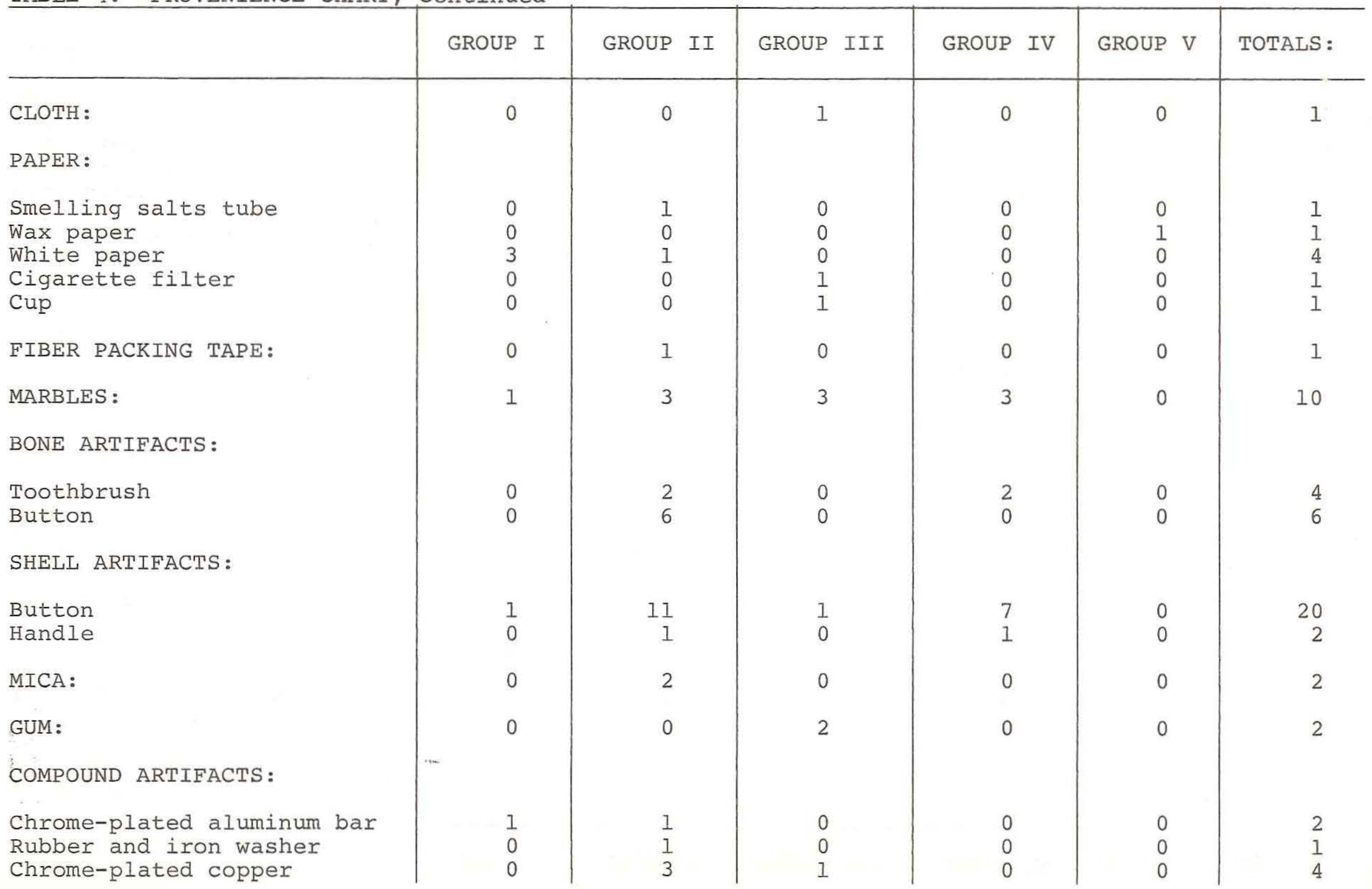


TABLE : PROVENIENCE CHART, Continued

\begin{tabular}{|c|c|c|c|c|c|c|}
\hline & GROUP I & GROUP II & GROUP III & GROUP IV & GROUP $V$ & TOTALS : \\
\hline $\begin{array}{l}\text { Brass/iron object } \\
\text { Iron/compound handle } \\
\text { Spark plug } \\
\text { Glass/copper light bulb base } \\
\text { Pearl-handled pocketknife } \\
\text { Gold/glass ringset } \\
\text { Denture }\end{array}$ & $\begin{array}{l}0 \\
0 \\
0 \\
0 \\
0 \\
0 \\
0\end{array}$ & $\begin{array}{l}0 \\
1 \\
0 \\
0 \\
2 \\
1 \\
1\end{array}$ & $\begin{array}{l}0 \\
0 \\
1 \\
2 \\
0 \\
0 \\
0\end{array}$ & $\begin{array}{l}1 \\
0 \\
0 \\
0 \\
0 \\
0 \\
2\end{array}$ & $\begin{array}{l}0 \\
0 \\
0 \\
0 \\
0 \\
0 \\
0\end{array}$ & $\begin{array}{l}1 \\
1 \\
1 \\
2 \\
2 \\
1 \\
3\end{array}$ \\
\hline COAL : & 66 & 308 & 8 & 0 & 0 & 382 \\
\hline SLAG : & 6 & 380 & 15 & 0 & 12 & 413 \\
\hline ANIMAL BONE: & 49 & 1378 & 986 & 1102 & 351 & 3866 \\
\hline RANGIA CUNEATA: & 0 & 10 & 0 & 3 & 0 & 13 \\
\hline PECTIN: & 0 & 14 & 0 & 0 & 0 & 14 \\
\hline OYSTREA VIRGINICA: & 18 & 171 & 13 & 29 & 7 & 238 \\
\hline SNAIL: & 2 & 3 & 1 & 0 & 0 & 6 \\
\hline FISH SCALE: & 0 & 1 & 0 & 1 & 0 & 2 \\
\hline EGG SHELL: & 2 & 0 & 0 & 0 & 0 & 2 \\
\hline $\begin{array}{l}\text { FLINT FLAKE: } \\
\text { WOOD: }\end{array}$ & 10 & 21 & 5 & 0 & 1 & 37 \\
\hline $\begin{array}{l}\text { Post fragments } \\
\text { Muntin fragments }\end{array}$ & $\begin{array}{l}1 \\
1\end{array}$ & $\begin{array}{l}6 \\
1\end{array}$ & $\begin{array}{l}0 \\
0\end{array}$ & $\begin{array}{l}0 \\
0\end{array}$ & $\begin{array}{l}0 \\
0\end{array}$ & $\begin{array}{l}7 \\
2\end{array}$ \\
\hline
\end{tabular}


TABLE 4: PROVENIENCE CHART, Continued

\begin{tabular}{l|c|c|c|c|c|c}
\hline & GROUP I & GROUP II & GROUP III & GROUP IV & GROUP V & TOTALS: \\
\hline Shingle fragments & 1 & 0 & 0 & 0 & 0 \\
\hline GRAND TOTAL: & 3849 & 26410 & 14344 & 8664 & 4461 & 57728 \\
\hline
\end{tabular}


APPENDIX 2

TEST EXCAVATIONS FOR THE SAM HOUSTON LAW OFFICE

In early May 1979 Dr. James E. Corbin of Stephen F. Austin University excavated eight small test pits to a depth of about $40 \mathrm{~cm}$. around the law office prior to planned restoration efforts. The purpose was to determine whether the present structure sits on its original site.

The law office is a 5.6 x 5.6 meter structure built of square-notched logs set on stone corner piers. It presently has a shingled, pitched roof and an uncoursed rubble masonry chimney on the east end. The door opens to the north and a small window is present on the south wall.

Test Pits 1 and 2 ( 1 x $1 \mathrm{~m}$. square) were placed at the southeastern and northeastern corners. Test Pits 3 and 4 were excavated on the interior between floor joists. Test Pit 5 was a narrow trench on the west end of the structure. About one meter west of the structure was a rubble "road" or walk surface. This surface contained white gravel, tar and brick fragments and was between five and ten $\mathrm{cm}$. below the present surface. Test Pit 6 was excavated one meter west of Test Pit 5. Test Pit 7 was excavated 4.6 meters north of the structure. Test Pit 8 was placed 18 meters north of the structure and contained no artifacts. Corbin's results were not conclusive, possibly in part because of their small size.

In December 1979 a trench was excavated between the northeastern corner of the yard to the juncture of the eastern side of the front porch with the northern side of the house passing west of the law office. A sample of the fill was screened and produced the following items: 


$\begin{array}{lr}\text { Pearlware body sherds } & 1 \\ \text { Pearlware base sherds } & 1 \\ \text { Stoneware } & 1 \\ \text { Brick } & 9 \\ \text { Glass } & 2 \\ \quad \text { Unbleached } & 2 \\ \quad \text { Selenite } & 2 \\ \text { Brown } & 4 \\ \text { Windowpane } & 1 \\ \text { Pressed glass } & 1 \\ \text { Melted glass } & 14 \\ \text { Iron } & 1 \\ \quad \text { Unidentified nails } & 1 \\ \quad \text { Wire nails } & 2 \\ \text { Hook } & 1 \\ \quad \text { Door lock plate fragments } & 1 \\ \text { Iron wheel } & 1 \\ \text { Copper penny } & 1 \\ \text { Nickle button } & 2 \\ \text { Rubber button } & \\ \text { Shell fragments } & 48 \\ & \end{array}$

In view of the small size and limited depth of the investigations in the vicinity of the law office, it cannot be stated that there is or is not clear evidence for the presence of the law office on its original location and the presence of undisturbed original deposits. It was clear, however, in the trench examined in December 1979 that the dark to medium brown zone that contained artifacts in the remainder of the site extended from about 15-40 cm. below the present surface suggesting that there may be important deposits in the area of the law office. 
TABLE 5

Provenience of Artifacts from

Corbin Testing of Law Office

\begin{tabular}{|c|c|c|c|c|c|c|c|c|}
\hline & 1 & $\underline{2}$ & $\underline{3}$ & $\underline{4}$ & $\underline{5}$ & $\underline{6}$ & $\underline{7}$ & TOTAL \\
\hline \multicolumn{9}{|l|}{ Ceramics } \\
\hline Pearlware body sherds & 1 & 1 & & 1 & & 1 & & 4 \\
\hline Pearlware rim sherds & 1 & & & & & & & 1 \\
\hline Pearlware base sherds & & & 2 & & 1 & 1 & & 4 \\
\hline Blue transfer & & & 1 & & & & & 1 \\
\hline Embossed & & & & & 1 & & & 1 \\
\hline Enamelware & & & & & & 2 & & 2 \\
\hline Stoneware & & 5 & & 1 & & & & 6 \\
\hline Porcelain body sherd & & & & & & & 1 & 1 \\
\hline Brick & 3 & 1 & & & 3 & & 3 & 10 \\
\hline \multicolumn{9}{|l|}{ Glass } \\
\hline Unbleached bottle sherds & 2 & & 2 & & 1 & & & 5 \\
\hline Manganese bleached & & & & & & 1 & & 1 \\
\hline Selenite bleached & 1 & 1 & & 1 & & & & 3 \\
\hline Brown bottle & & & & & 1 & & & 1 \\
\hline Green bottle & & & 1 & & 1 & & & 2 \\
\hline Lamp chimney & & & & & & 1 & & 1 \\
\hline Windowpane & 2 & & & & 1 & 3 & & 6 \\
\hline \multicolumn{9}{|l|}{ Iron } \\
\hline Unidentified nails & 9 & 41 & 1 & & 5 & 3 & & 59 \\
\hline Cut nails & 1 & & & & & & & 1 \\
\hline Wire nails & 13 & & & & & & & 13 \\
\hline Copper Penny & 1 & & & & & & & 1 \\
\hline \multicolumn{9}{|l|}{ Plastic } \\
\hline Hard sheet & 1 & 1 & & 1 & & & & 3 \\
\hline Mortar & & & & & 1 & & & 1 \\
\hline Plaster & & & & & 1 & & & 1 \\
\hline Roofing Compound & 4 & & & & & & & 4 \\
\hline Coal & 1 & 1 & & & & & & 2 \\
\hline \multirow[t]{2}{*}{ Rangia Cuneata } & 1 & & \multirow{2}{*}{\multicolumn{6}{|c|}{1}} \\
\hline & & & & & & & & \\
\hline TOTALS: & 41 & 51 & 7 & 4 & 16 & 12 & 4 & 135 \\
\hline
\end{tabular}

